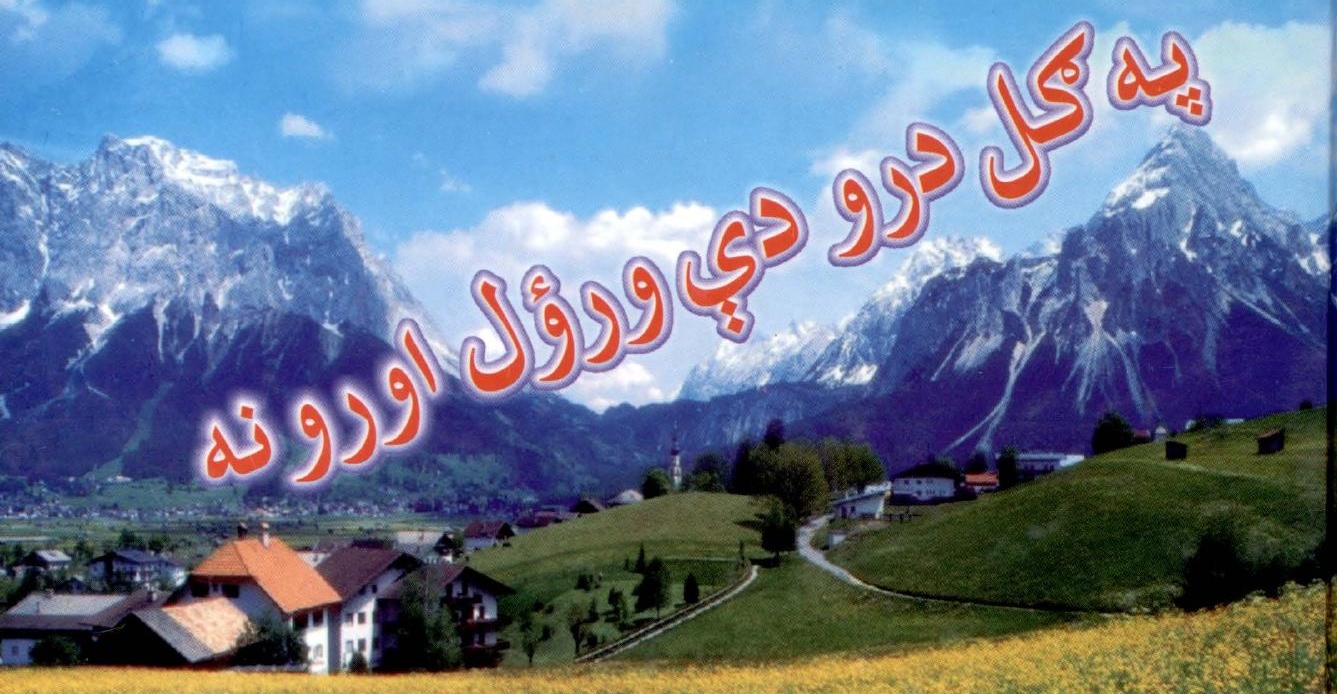

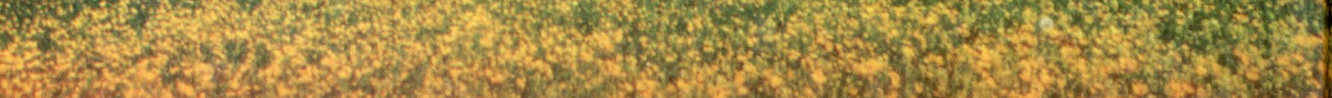

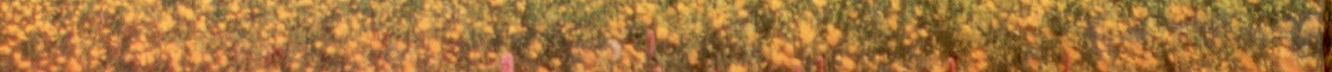

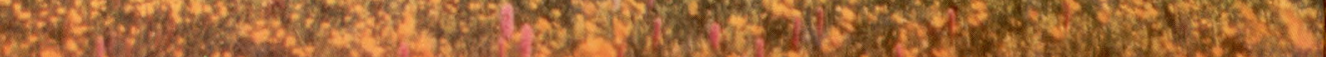

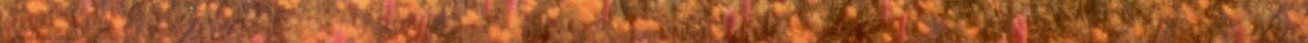

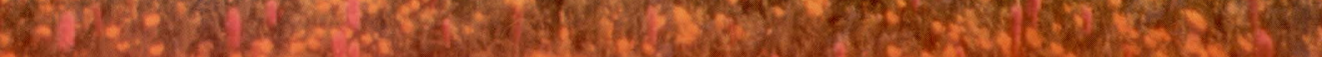
OU⿻

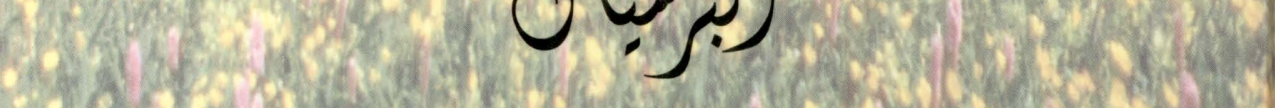

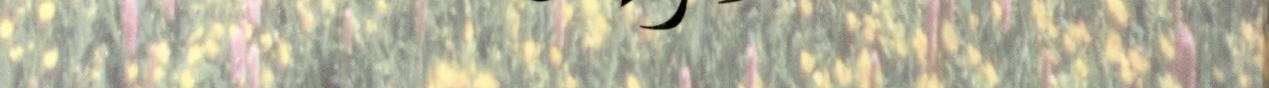

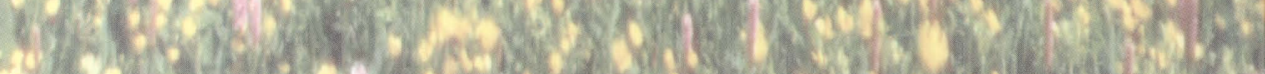

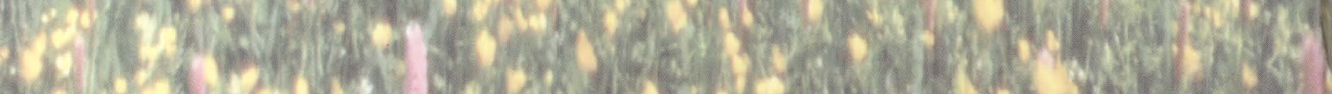

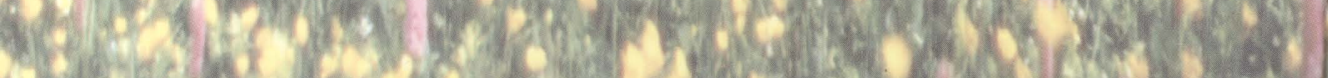

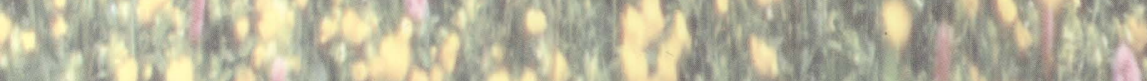




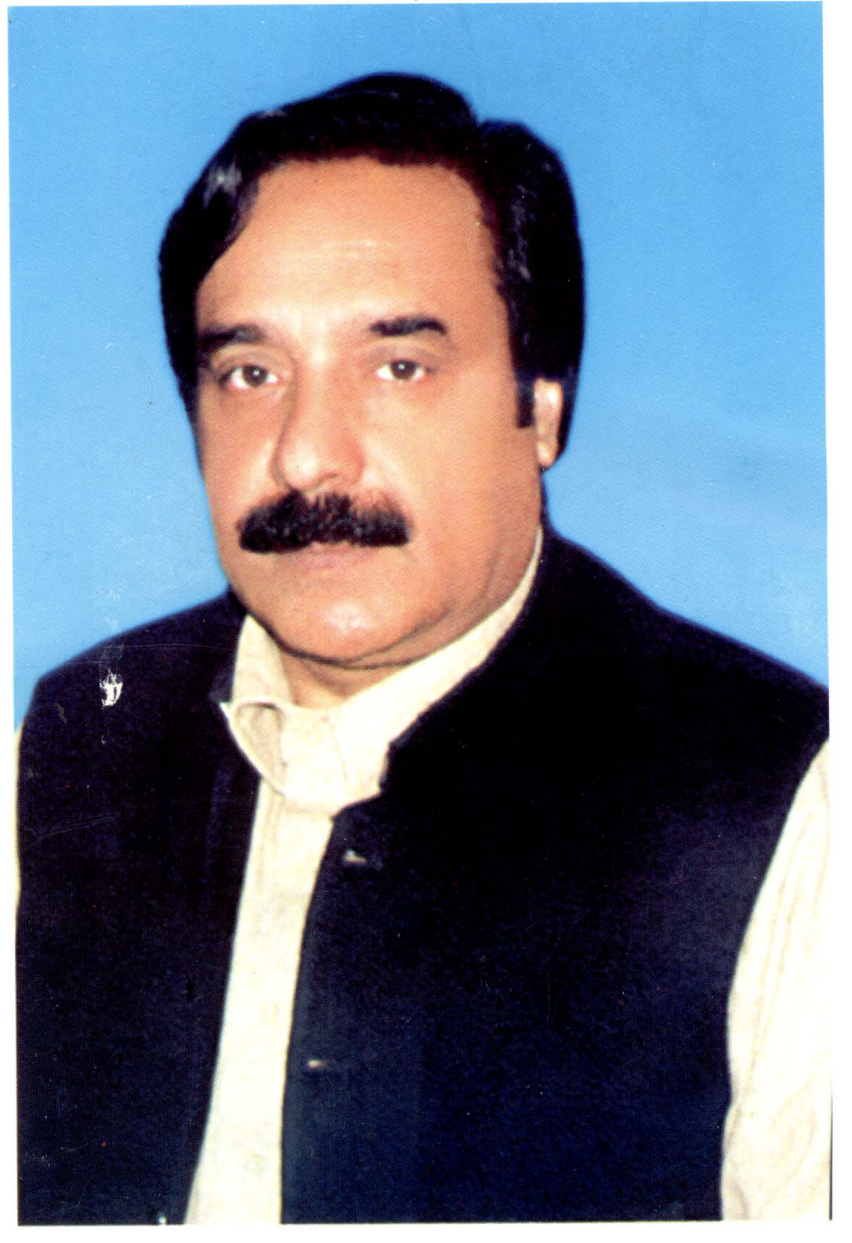

) אبر سيا 
-

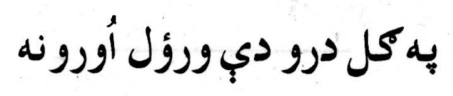

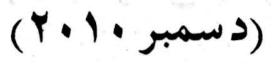

اكبر سيال 


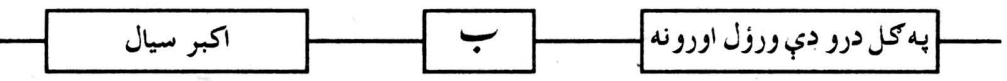

\section{جاب كو نكي اداره}

بنبنتون كلجرل ابسو سى ابشن اسلام اباد

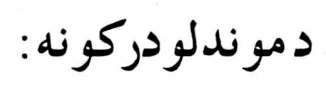

ا ـ دانش اكبر خان، نويد اكبر خان ـ باكى افغان تربلدرز بالمقابل

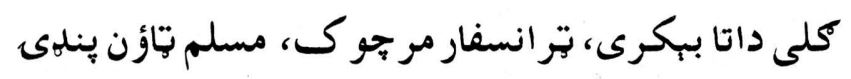

$$
\begin{aligned}
& \text { r - يونيور ستى بُكـ ابجنسى خببر بازار يبنبنور }
\end{aligned}
$$

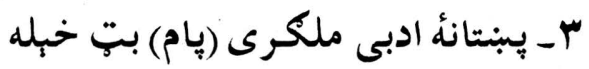

$$
\begin{aligned}
& \text { 0300-5292843: رابطه نمبر }
\end{aligned}
$$

E mail :- naveed_naveed14@yahoo.com I S B N NO:978-969-8428-03-07 


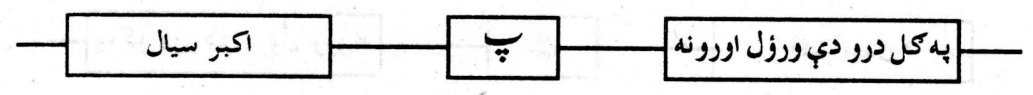

$$
\begin{aligned}
& \text { ليكو ال/كتاب بِّزّندنه }
\end{aligned}
$$

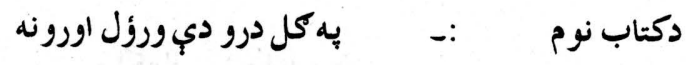

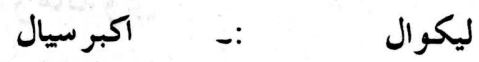

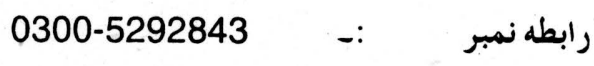

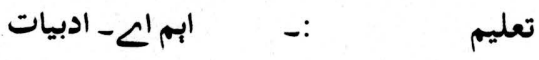

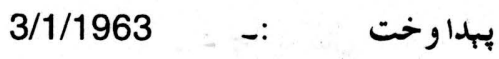

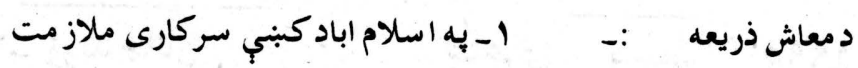

r ب به ا سلام ابادكبنب د جايان د سفارتخاني

$$
\begin{aligned}
& \text { د افسر انوديبنتوزبب استاذ }
\end{aligned}
$$

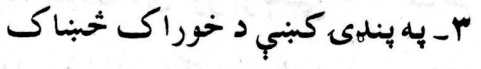

$$
\begin{aligned}
& \text { كاروبار }
\end{aligned}
$$

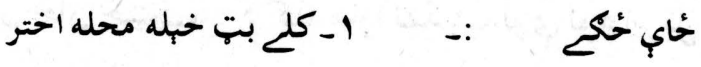

$$
\begin{aligned}
& \text { غونلمى ملاكنده ابجنسى } \\
& \text { r ب مكان نمبر } 109 \text { بلاكى نمر } 4 \text { مسلم } \\
& \text { تاؤن بنهى } \\
& \text { حسب نسب :- تركلانى- مست خبل- } \\
& \text { نيكن كلٍ جندول معياردير } \\
& \text { دجاب شمبر : - : }
\end{aligned}
$$

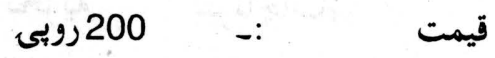

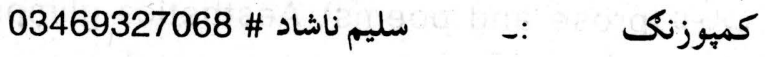

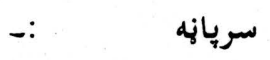




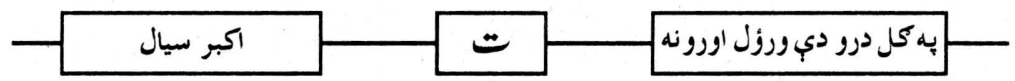

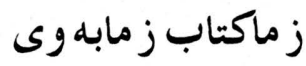

$$
\text { د بَاب كال }
$$

شاعرى دسمبر 1990

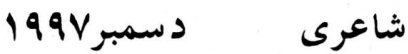

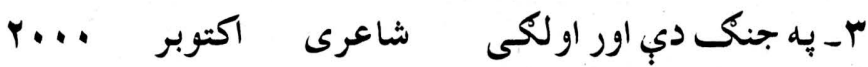

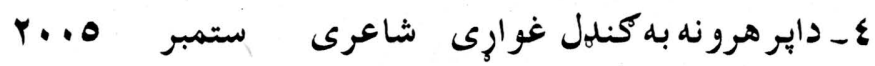
هـ خوشحال خان ختّك ـ د كَندهارا تهذيب لوي نوم ابربل

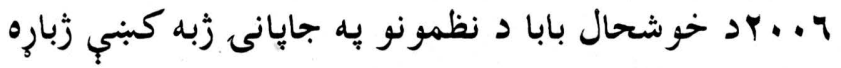

اكبر سيال - حيديقى ايشيزوكا

$$
\text { مؤ لفين :- }
$$

צ- اوبنكي اوبنكي مسكيتوب شاعرى جنورى 1..

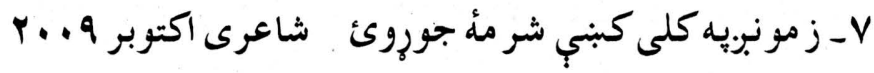

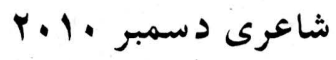

$$
\text { 1- يـهكل درو دي ورؤل اورونه }
$$

$$
9 \text { - د يُبنتنى تاريخ تنقيدى تجزيله }
$$

ناجاب (prose and poems) Aesthetics glimpse - 1 . 


\section{مالى}

o

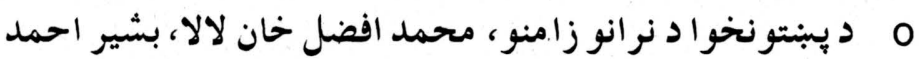
بِلور او ميال افتخار حسبن يه نوم-

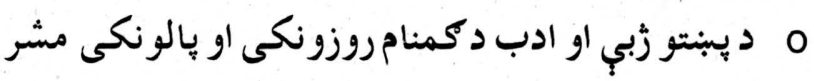

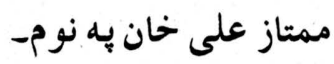

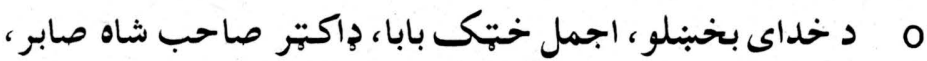

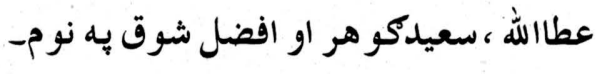

o م دكرانو ملكرو محترم لطيف لالا، محترم رحمت شاه سائل،

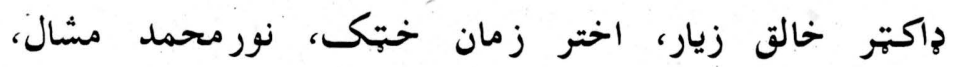
ذاكر حسبن، هارون باها، ديدار طائر ، محمد جاوبد خان لالا ، حبيب الرحمان، جاوبد بنكش، غلام يونس، مقرب خان، مهر خبداد

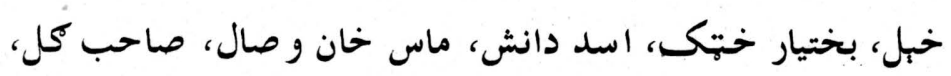

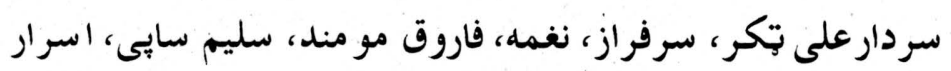

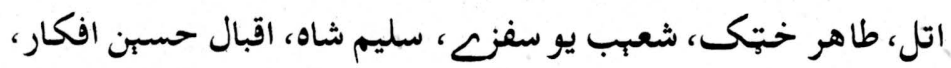
نعيم طورى، خالد حسرت، عزيز مانبروال او محترمب عصمت شاهجهان يه نو مونو داكتاب دإلى كوم -..-- (اكبر سيال) 


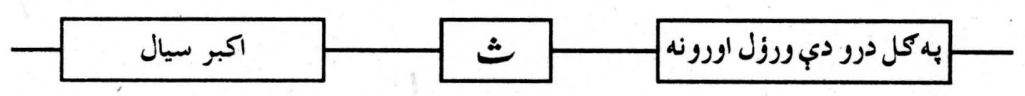

ترون

د اياز مندو خبل يه نوم 


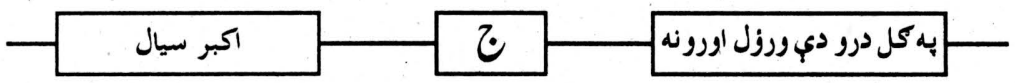

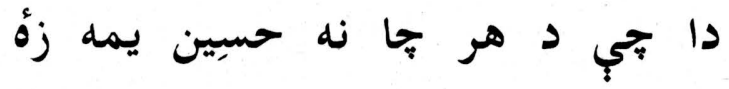

يه خيلو سرو وينو رنكين زيمه زه

يرون يردو، نن قالابند كرم خيلو

و خته د "تور،" هغd "متين" يمه زه 


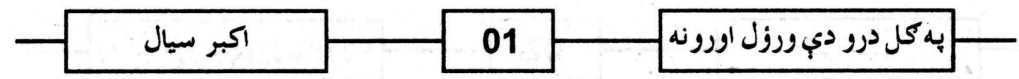

\section{شحُه تاثرات}

\section{ممتازعلى اسلام آباد}

اكبر سيال هم زما كشّر ده هم دو ست- خوب.ب

خبري كوى، بنكلى شعزونه ليكى او مزبدار او درانهُ ادبى

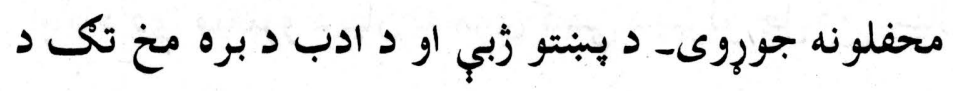

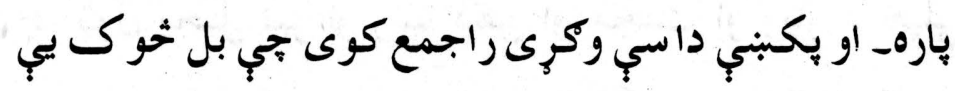
سوج هم نهُ شى كولي- خحئورحي اوشوي د دهُ يه يو شعر ما خيله اختلافى رائى وركره اوئي خندل اوخبره ختمه شوه-

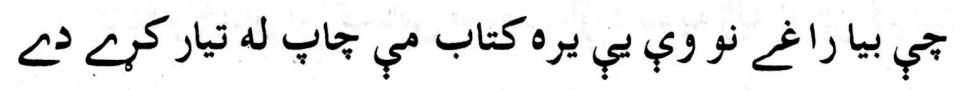
دوه حملوركربنب يري اوليكهـ د بده مرغه ورته ما بنه

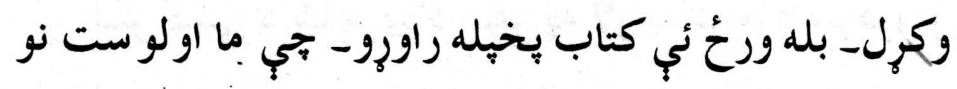

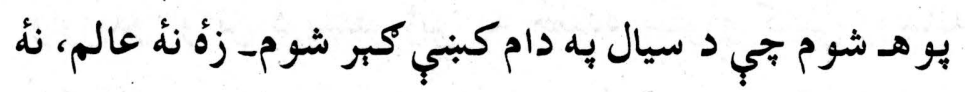
فاضل، نهُ نقاد، نه اديب او د سيال د شاعرى يه مجموعه

$$
\text { كبني ز ماليكـ! اوتختم نو جر تهـ }
$$

خبر خلاصبدل كر ان دى نو د غه دي دا باني مي توري 


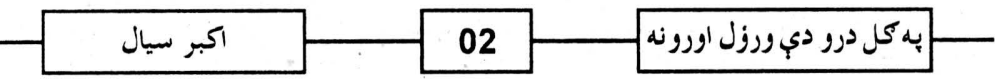

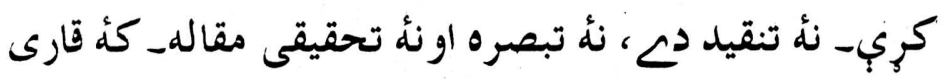
يبي اونهُ لولى نو يه ما احسان او كئز ما دليكـ سره اختلاف لرى نو يه حق دى- دسيال دياره دو مره وئيل شم تجب حق مي حقدار ته اونهُز سولي شو -

اكبر سيال د يبنتو زبب نامتو شاعر دهـ ، كهُ فكر

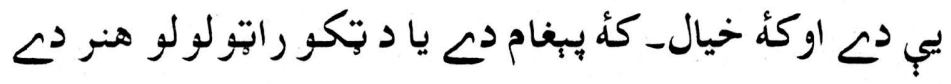
او يا د دي ملغلرو د بيان يه مزى كبنب د يبرلو جل ده سيال دا تول يخهيل تبز او رسا ذهن او محنت او ويار د خيلب يو هي به لمن كبنب رانغارلى دى حيكه يب يه كلام كبنب يو خو الب او خوبروالي ليدة شى-

د دهٔوجدان او حساس طبيعت او د دهُ يه زبه او فن كرفت

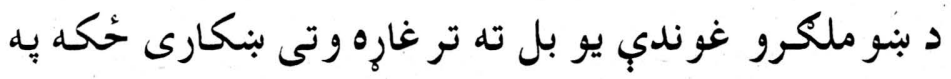
لب. عمر كبنب د شاعرى د سفر يه لار يه دو مره سردرو ور واوريدو او نن د يبنتو زبي بيه حُلنده ستورو كبنب روبنـانه

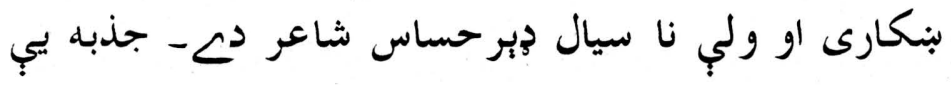

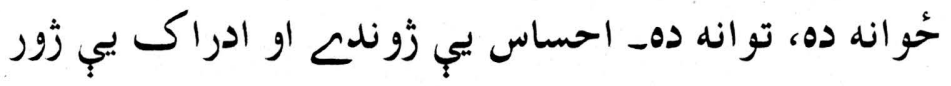

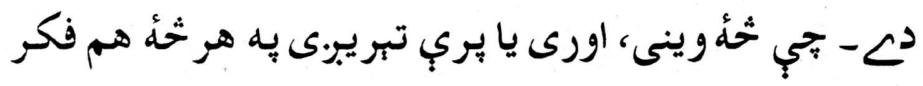




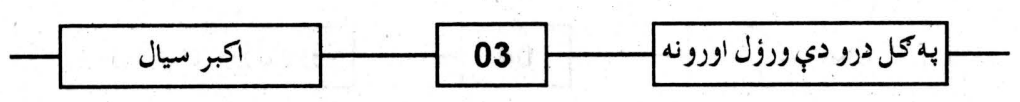

كوى اوهم بري يوهبدل غوارى- اثر تري اخلى او تبي

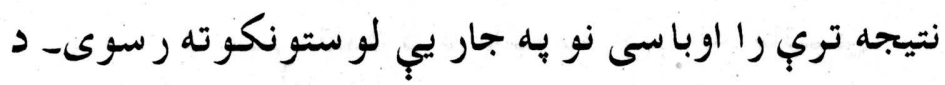

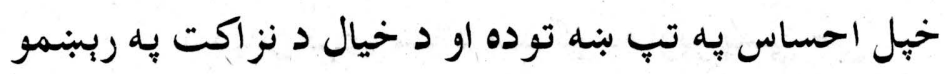

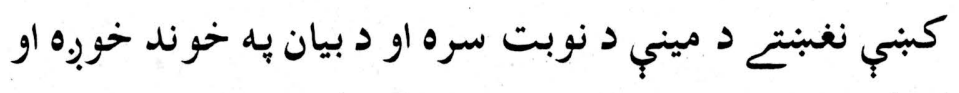
د انداز بيان به رنكو نو بنائستهـ د سيال يه شاعرى كبنب يه ديه

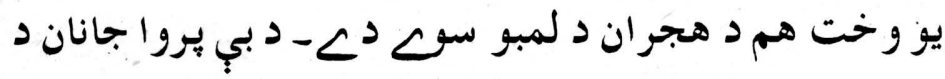

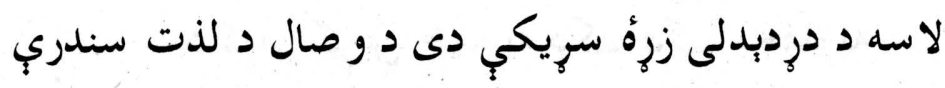

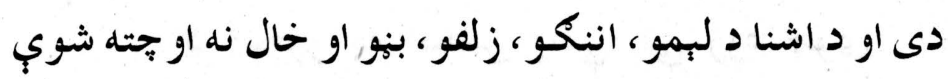

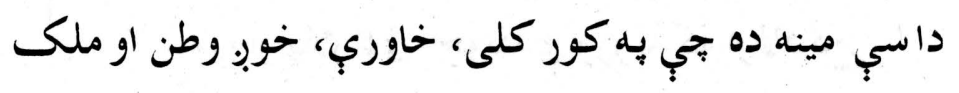

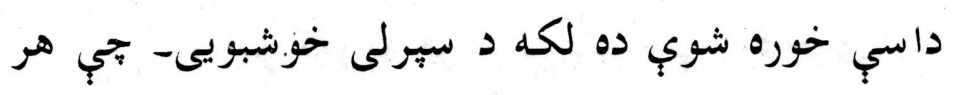
خو كى ئب هر خو ا محسو سوى توز له شاعرى يب هم د د ذغه مينب د رنكونو كلدسته دهو وائى ه ما د زوند د رنكينو به كور كبنب بند كره ياره زرة مي د خهل زرةه سره يبوند كره

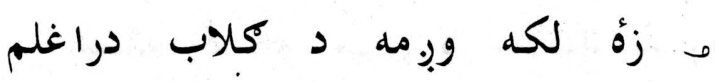

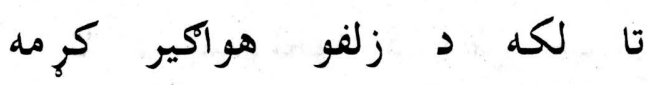

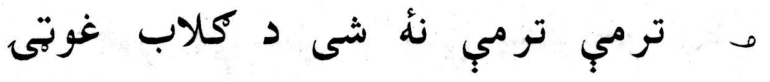




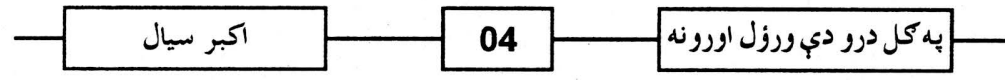

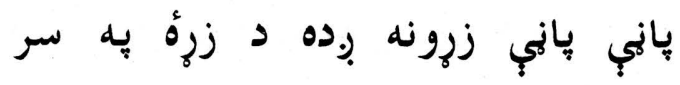

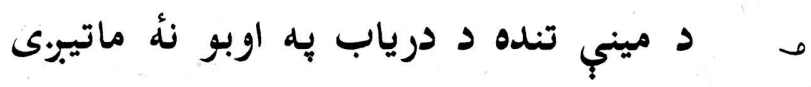

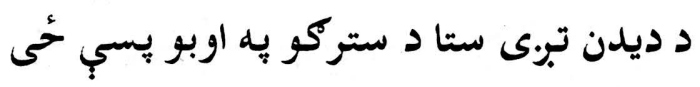

دغه مينه د كور، كندى اوكلى بس منظر كبنب خهل رنكـ او جوش لرى وائى

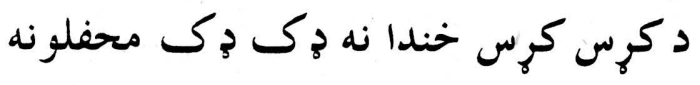

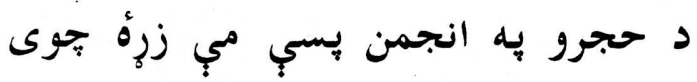

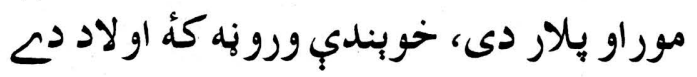

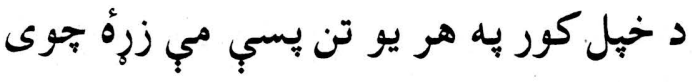

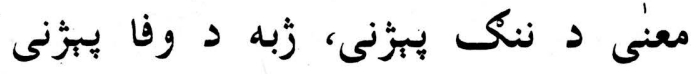

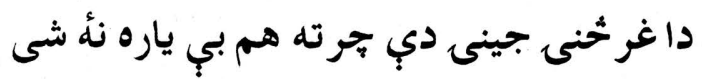

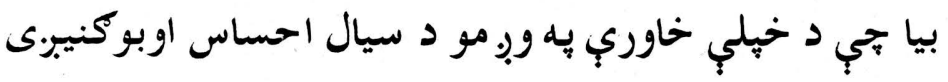
نو د ميني غورحُنك يب د فكر ورشى لب. خيال اوكرئ-

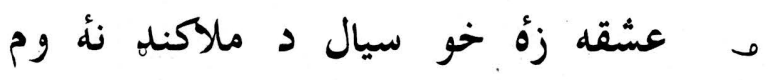
تا د بِبنتونخوا د وطن مير كرمه سئ هـ - جوره جي شى د مينب پبنتونخوا وطن 


\section{- 05}

دا حُل يهل جركّه به لر او بر له حُو

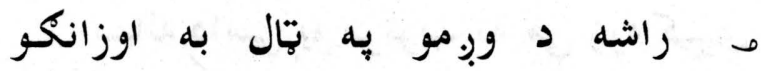

كورته به د حسن اشنغ له له له له له

هـ مودي اوشوب د عرش نه تماشه كوب د فرش

يه خدايه ! داوطن مي د خدائى د مخخ نه جوريره

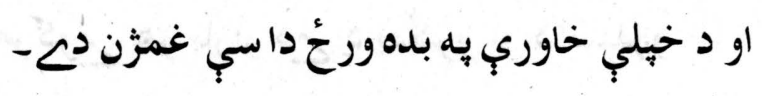

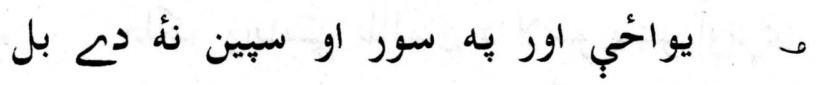

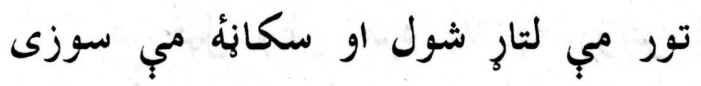

دغه مينه جي يه غورحُنكونو د يبنتو نخو اد لورو شخوكو نه

راكوزه شى او د خهيل وطن يه شنو ابادو مبدانونو او سوو

مبرو خوره شى نو تله به وايب د خوبر وطن بنكلي لبلى له ئي

يه نازكو اوكى د كملونو رنكين شال اوغورؤه- خو دا مينه

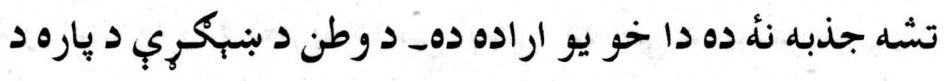

عمل يو اعلان دهـ د دب د ودي د ياره د تيارى يو دعوت

دع تولو وكرو ته، تولو وطن داروتهـ جي خوبر وطن اباد

كرو او د هغه سرى د ستركو ايستو قسم تجي خوبِ وطن ته يه

$$
\text { بدو ستركى كورى وائى- }
$$




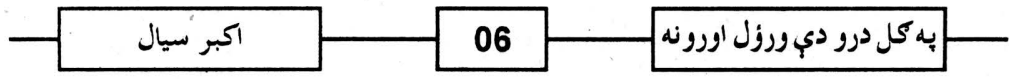

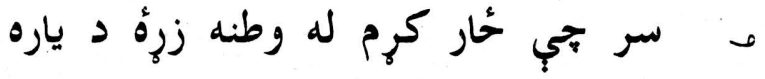

سياله داسي يو نرتوب ته مب زئه كيبرى

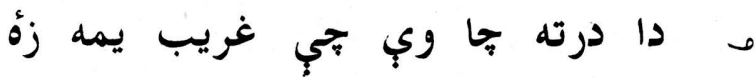

وطن مي باغ ده او اولس كلونه

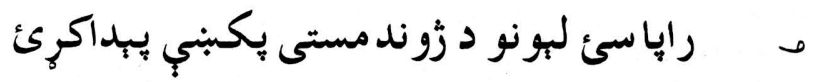

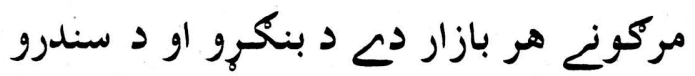

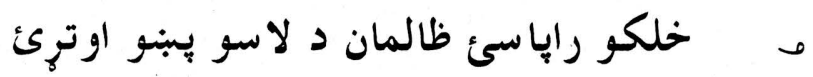

د خيل وطن هره بلا يه زولنو اوترئ

هـ كرم به ئي هيه كوتو كبنب ريبنب ريبنب

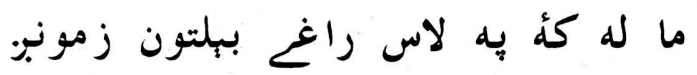

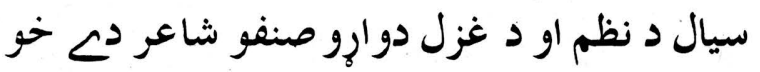

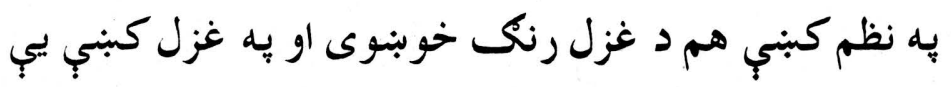

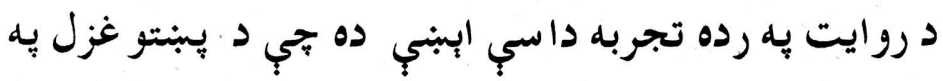

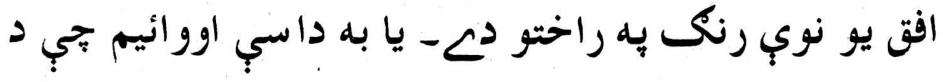

سيال غزل د روايت خوشبويى لرى خو د تجربو له كبله د دؤ

غزل د هر جا نه بيل رنك لرى- رون، تازه او د توان نه

زئك-وايى 


\section{اكبر سيال}

\section{7}

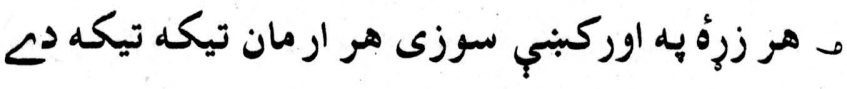
مونب. خو مره يه خوند تبره كره كباب كباب حورانى

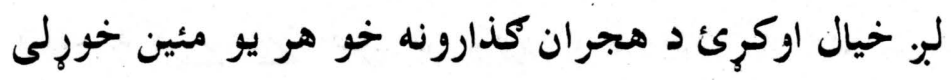
دى- به دي اور تول سوى دى او حئكه اكثر كيله مند دى او د غه زرجا زارىى اوكوره سيال بري خحنكه فخر كوى او كو مه

$$
\text { زبله اوخدُ بيان! }
$$

هـ زما خلهُ زما يـه خيلو وينو سره ده

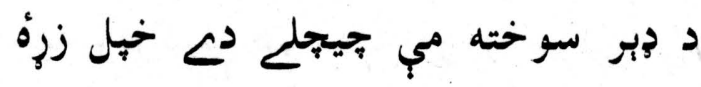

د بيان او اظهار دا انداز منفرد دهـ- روايت او تجربه يو بل سره اخلى بنكارى- خو د هر. جا نه جدا- نوب طرز، نوي

$$
\text { الار }
$$

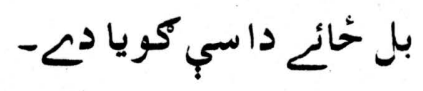

هـ اور ته مهٔ نيسئكلونه اور ظالم دع اور قاتل ده

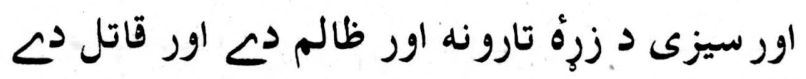
دا غزل تجي د روايتى تنقيد يه اصولو نظم بنكارى د غزل يه زمكه يو نوب تجربه دهـ رمز او كنايه يكبنب به نفس 


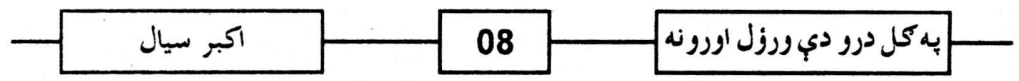

مضمون غالبه نهٔ دهـ خو د موضوع يه تعلق تجب دا انداز

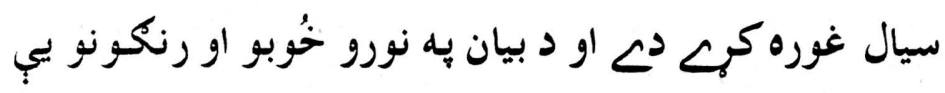

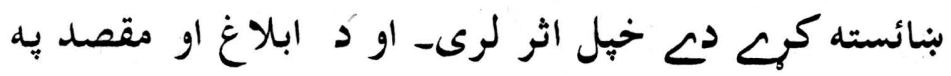

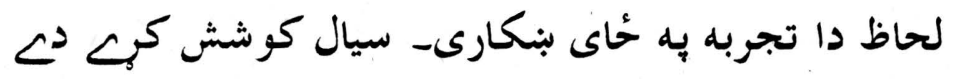

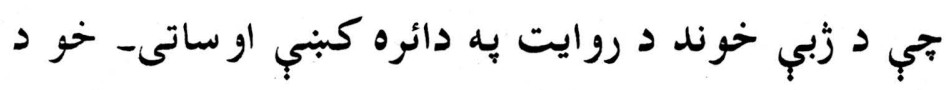

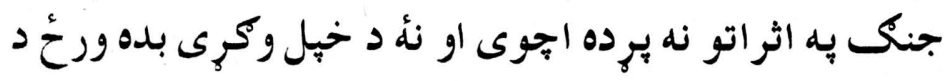

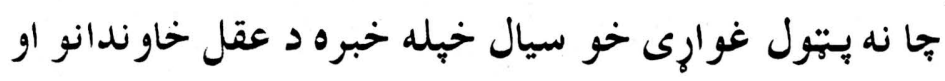

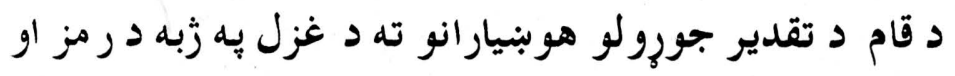

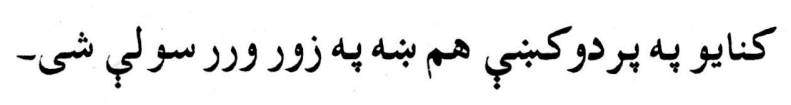

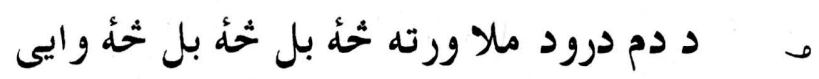
دا خلق خو بيمار دى د بنكـرو او د سندرو دلته هم د تجربي رنكى د كتو ديه يه دي شعركبنب هم او يه ديه

$$
\text { دي تول غزل كبنب هم- }
$$

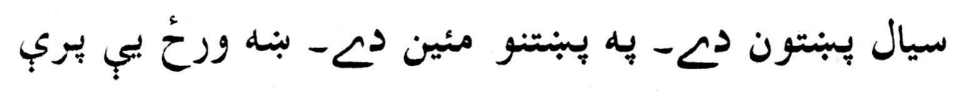

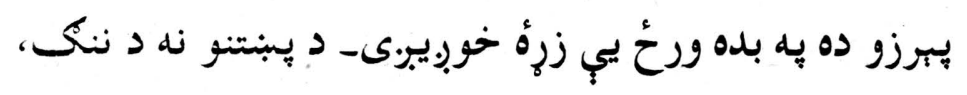

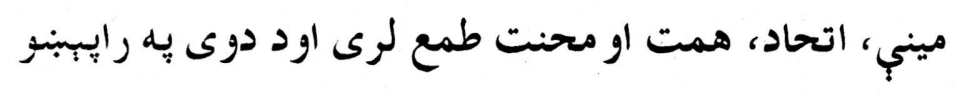

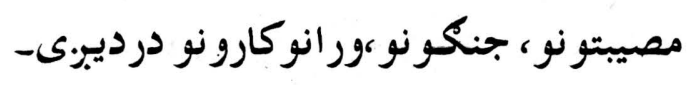




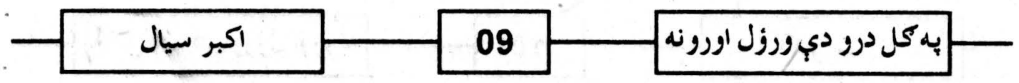

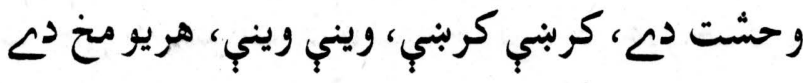

مسك مسكح كلاب د بي وسى دمخ نه جور كره

سياله اور وحشت وحشت بربريت ده تشدد دي

سياله بج كره خيل نسلونه اور ظالم ده اور قاتل ده

مـ غر زمونبر، رمه زمونب. او شهون زمونب.

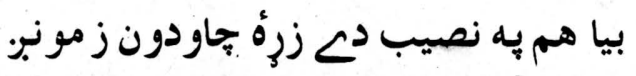

خداى خبر هي عقل تربنه جرته لاز

كر حُحى جي به دشتو كبنب ببنتون زمونب.

دا كربنه به ليكو يه تندى د وخت

نن زمونب،، سبا زمونب،، يوون زمونب.

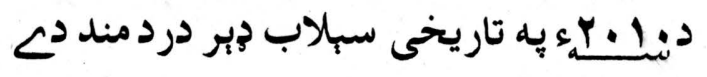

ه جي اباسين شى يه غورحُنك خيل برده نهُ هيثزنى

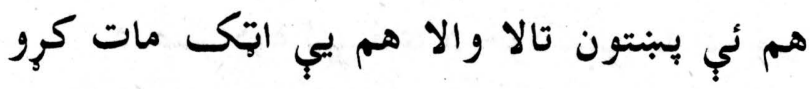
زما د زره نوبنار يبي داسي به سبلاب لاهو كرو كله جا بند به نيمه شيه كبني د ور سك مات كرو دلته بياهم تلميح شته او هم د سبلاب يو سببـ د ور سكـ د بند دروازي يه رو غه صلاح بر انستب شوب دىــ هغه 


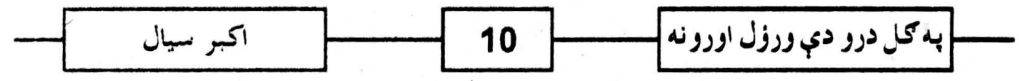

وخت جي د سوات درياب (خيالى) د غورئنكونو به جها

$$
\text { تاريخى جوش جار سده به جيو كبنب اورلهـ }
$$

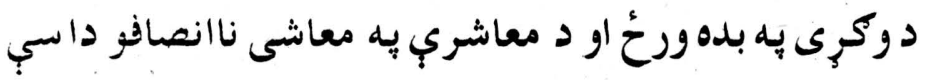

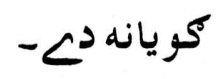

ـ شلهل بلهل زاكئ باكئ خيرن خيجن لاسونه دا دى د زوند د ارتقاء د كملبدن لاسونه

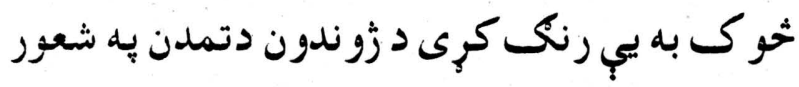
د خرو خاورو د كورونو زير زببخن لاسونه

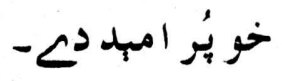

هـ بله يوه خطره هم نشته كلستان ته زمونب.

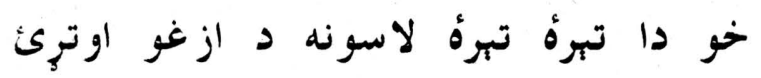
هـ د مركى او زوند د ازيت به بريد ولاره كله د صبر دوه لبي دعا د خودكشى نه بنه وى ليد

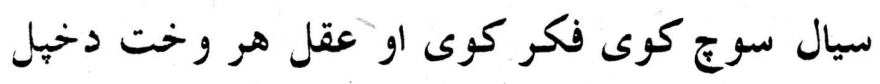

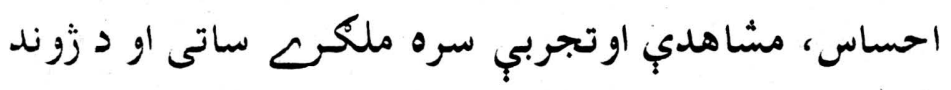

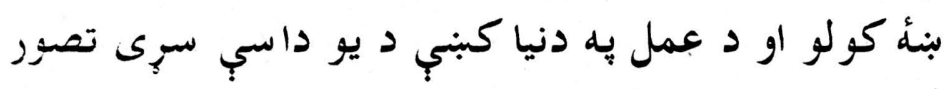

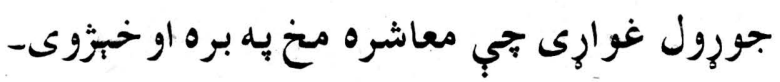




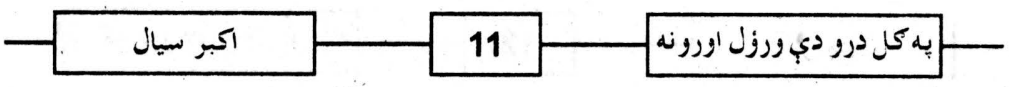

هـ ترشو يجي مو دعقل به درمان جولي نهٔ وى

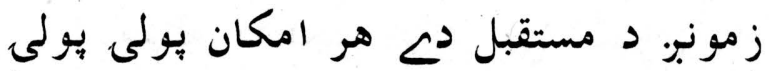

ه لاسونه ترل غوارى د ازغو د جنك ببرو

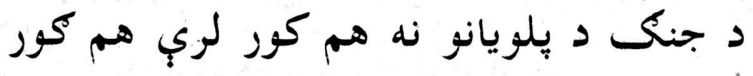

هـ لكونه افغانان يب يه يو تبغ باندب حلال كرل

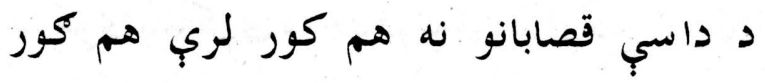

هـ د بِنتونخوا د وطن بنكلو يه زرا كبنب اووب

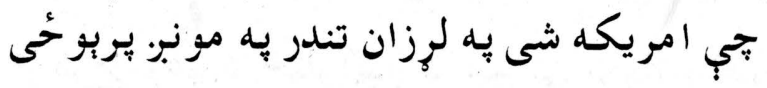
د اختر به راتلو حيكه خوشحاله ديه تجي-

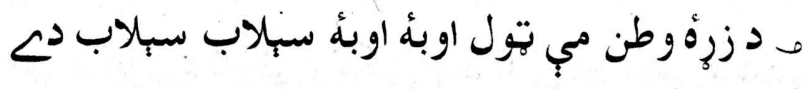

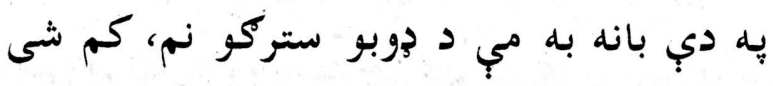

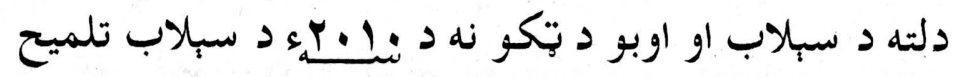
جوزيبرى-
ه يبنبنور سوزى كؤه وانه مب سوزى

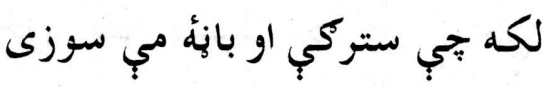




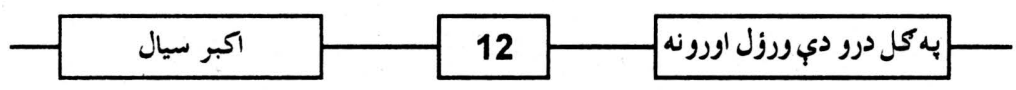

زهُ او وطن يُو ِِه يو تار تهلى

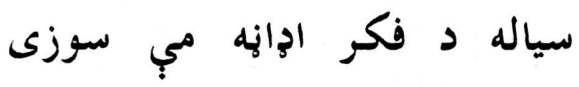

دا د نننو واقعاتو بـه راتلونكى وخت كبني يه دي ز مكه او د

دي به او سبدونكو جي ثحئ اثرات غورحُوى د هغب د سبا

بيشن كوي ده ده اويه دب وجه دا آواز او جتتوى-

ه يه بي ستركو ، يه بدرنكو ، د د بمونو سوداكرور

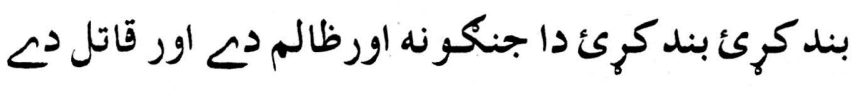

دلته د سيال د يو بل غزل ذكر ضرورى بنكارى دـ د دريو كالو

مخكبنب خبره دهـ د كل وطن باغيجه كبنب بلبلانو جغار

شروع كرك ؤهـ د خهيلوابكى د سبرلى د راتلو طمع وهـ

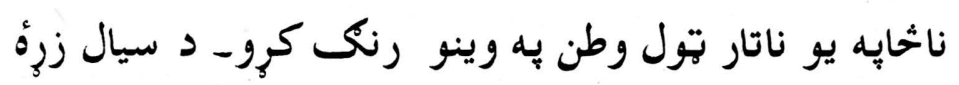

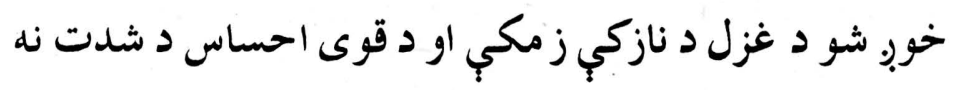

يبي داسب مرثيه را اوويسته جي ذيبر به غزل مئين او د غز الو

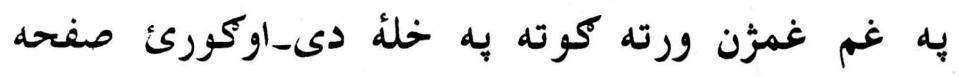

نمر 1. 1.

خور شو بِرلح د كل غوتيى به سر

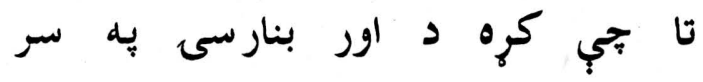




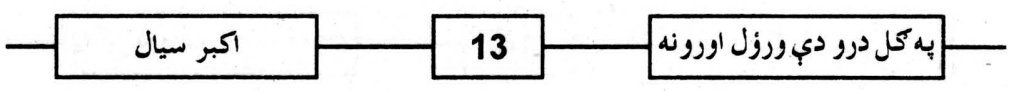

د غزل يه زمكه مرثيه او دو مره بنكلب- د نظم نقاد به يقينًا

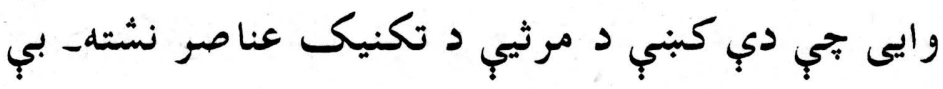

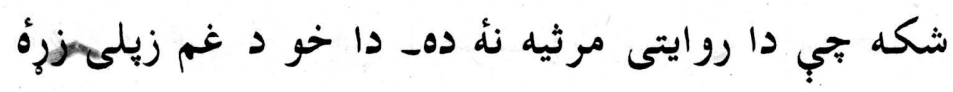

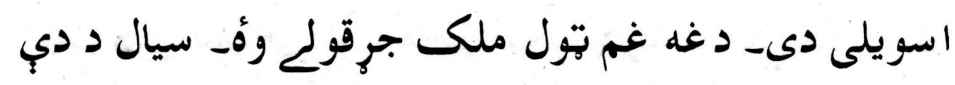

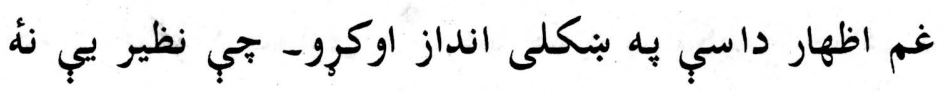

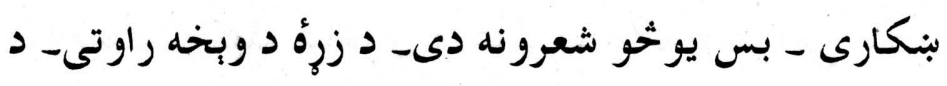

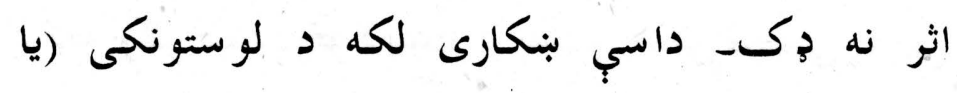

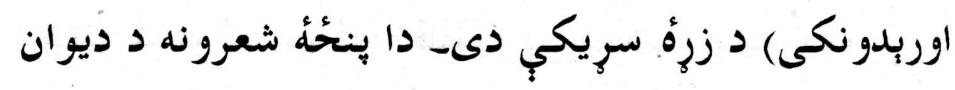

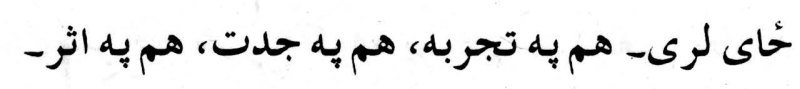
د غزل مورخ وايى جب غزل اول اول بـه ساده

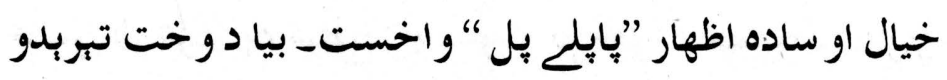
سره سره يكبنب تجربي كبدي- موضوعات زياتبدل- فكر

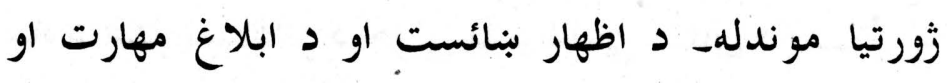
بو خو الى حأى موندةٔ تر دي جي د دكلاسيكى دور استاذانو

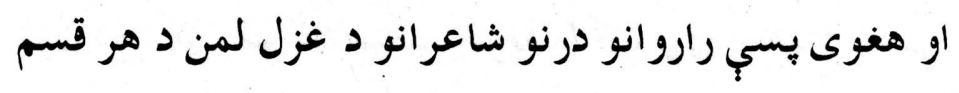

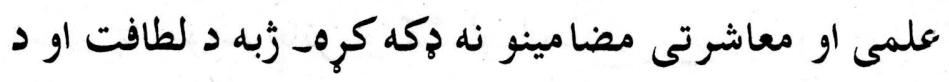
اظهار يه فنى كالو د ناوي هسب تياره شوه-وريسب ادوارو 


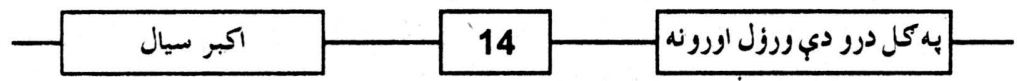

كبنب شاعر انو د غزل سرخخنه د لطافت او د فن د باريكور د حسن يه كلونو اوكرهـ تر دي بي نورلنسمه عيسوى صدى راغله او غزل لكه تجي يه خوب اودهُ شو- يه شلمه صدى كبنب جب سماجى او سياسى تحريكونه شروع شولـ نو

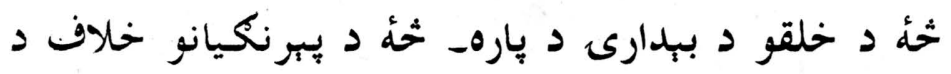
مزاحمت له كبله شاعرى د غزل نه زياته د عوامى مشثن ذريعه اوكر حيدهـ خو د يبنتو او يبنتنو خوش قسمتى وه بجي

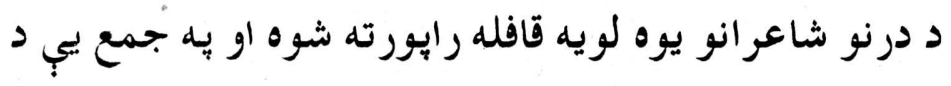
نظم او غزل سرخحنه شروع كرهـ يو خوا عبدالغنى خان د

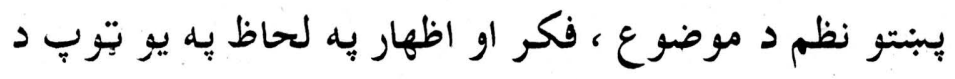
عالمى شاعرى يه سطح راو ستو او بل خوا د حمزه شينوارى يه سرخبلى كبني غزل داسي غزونب اوكري تجب غزل يه يو

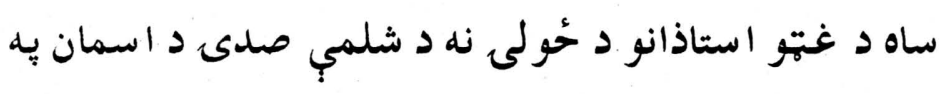
نصف النهار او حُلبدهُ عجيبه خبره ده يو خوا د حمزه صبب غزل ده جي هم كلا سيكى خوند رنك لرى او هم د شلمب صدى يه موضوعاتو او كشّالو لمبهدل دم او بل خوا د د

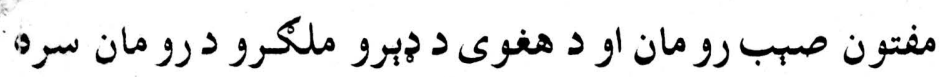




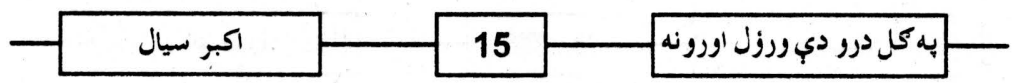

سره د زوند د كشالو او د معاشري د زنحُيرونو خلاف د احتجاج يُر اثره د اظهار او فن يوه بنكلب تجربه دهـ دغسب غزل د ديرو درنو شاعرانو يه تحريك او تخليق د شلمب

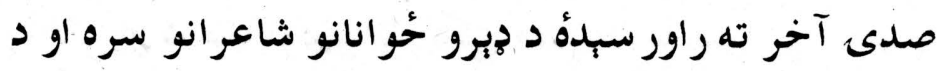
د غه صدى يه ورو ستو وختونو كبني تجي د سيال تركوتو دا مزع راور سبدهُ نو د موضوع د تنوع او د زببي او بيان د نوو نوو تجربو جينب يه بهير وب- سيال د دغه قافلي لاروب دع - د درنو مشرانو نه ورو ستو راروان ده خو خيل بيل انداز لرى- داسب بنكارى جي د يويشتمب صدى ادبى مورخ به د دهُ به شاعرى او فنكارى ليكل ضرورى كنىخبره مو د سيال د تجربي كوله جي روايت سره اخلي دهـ داتجربه هم موضوع كبني دهـ هم بيان كبنب او هم

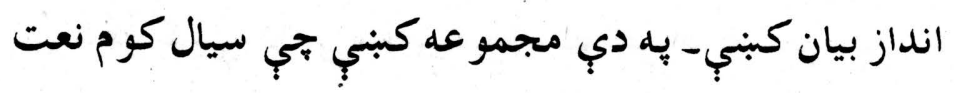

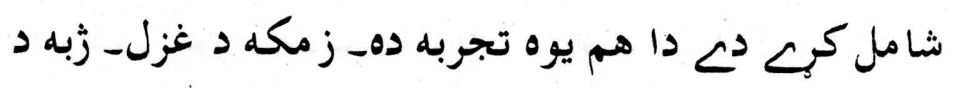
غزل، انداز د غزله او عقيدت دومره تي رشك بري

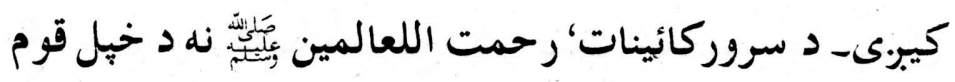
د بنبكري سوأل كوى نو وايى "جي دا يه وير لرلى خلك 


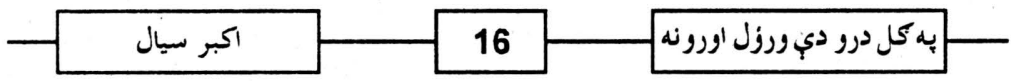

لب.ه سا واخلى" نون تركيب ده - دعا كبنب بس د نن د

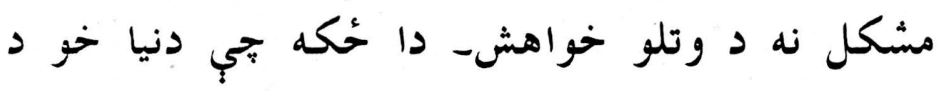
مشكلاتو كور دلهـ بس تجي نن دو مره اوشى تجب قوم سا واخلى او د صبا نوى راتلونكى مصيبت ته تيار شىـ هم يه دي نعت شريف كبني لانديني شعر دوارو مصرعو كبنب د نوو تركيبونو راو ستل يه داسب انداز بجي تصويركشى موثره

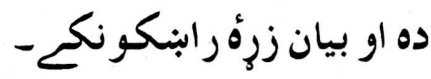

ه ـ يورته اسمان ته يه دعا وو كَل ورين لاسونه د جا يه وينويجي ككر نهُ كرل حسبين لاسونه يو خوا د "مل ورين لاسونه" دا بنائسته او نازك خياله تركيب او بل خوا د دب يه منا سبت د "حسين لاسونه" ساده تركيب هي نوى بنكارى- دو مره يه ساده طريقه دا بنكلا يه دي شفر كبني داسب حُاى شوب ده هب د لو ستونكى يه ذهن كبني يوره تصوير جوروىى دا نعت خو د خبر الاناميَّيَّيَّي د شلو كالو د نبوت قيصه دهـ د هغوى د رشتونولى، د

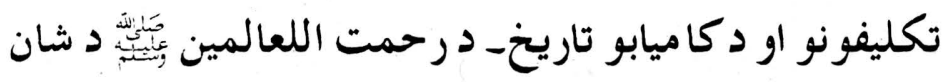
بيان ده خو يه دو مره لبوو كربنو كبني دو مره ساده تتكو 


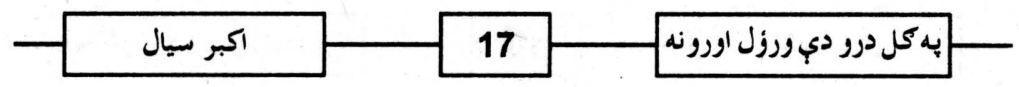

كبنب- دو مره وبنا او داسب يه عجز ، يه خوند او يه عقيدتداد سيال د فن، جدت او تجربي يو بل مثال ده هر مشرقى شاعر د يار يه مينه هم شتئه من ده -

هم سوب ستّكور د ديار تصوير هر مئين به خيل خيل انداز يه شعر كبنب راكابِى- سيال د خيل "محلبدن" تصوير داسي جوروى "سره لاسونه، ستركي تورب، د كل بانه،" دلته هم ساده، سو جه، لطيف تصور ده- خو د يار تصوير دلته مكمل سكل شوب نهُ دب - بل حُاى كبنب وايى هـ - داغرونه غرونه زلفي اونازك نازك كملونه دا جا د نازولو يه سر بار كره زندكى

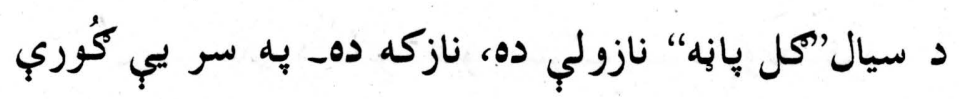
كُورب زلفي دى- هغه خو دغه هم سمي نهُ شى كرحولي جي درنب دى اوس يكبنب جا كملونه هم اوتو مبل- د دي نازكي نازولي زوند شخو مرهكران شو ! نازك خياله سيال يه

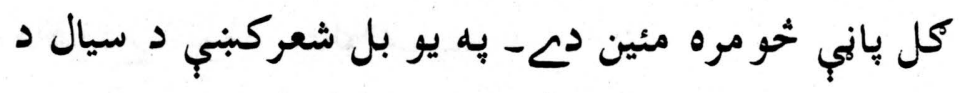

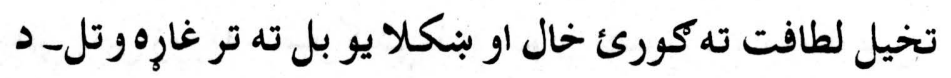




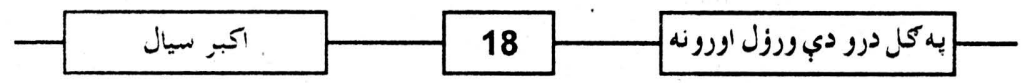

اننكسو يه سرو لمبركبني خال د خندا نه شين شور

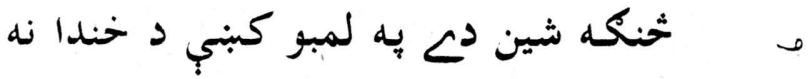

ستا د زنب د مست خال نه مب توبه كر:

او د غه د بنائست تصور كله كله د زلفو نرم والبي د رببنسمو

سره سم كرى او بانئه تي نبغ شى، يه ككو برند شى- نو

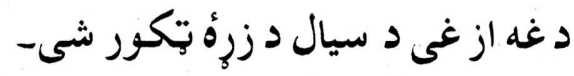

م رببنمينو زلفو ته دي وايه تجي يه ستركور مئين

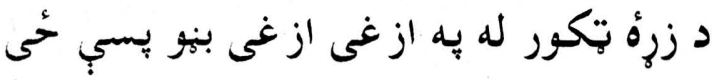

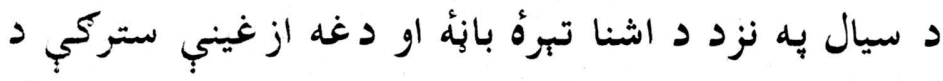
حُسن روح دِ او دي ته هفهُ زوند وايى-

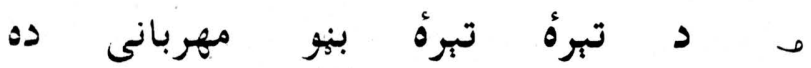

سيال د غنو غنو ستركو سره زوند كره

د سيال شعرونه د دغسب نوو تركيبونو او تصرواتو نه ديك

دى لكه جي كلال يه يايه د ختتو نه لوخى جوروى ناز كى

ناز ك او بنكلى بنكلى د غسب سيال د تركيبونز جزوزولو

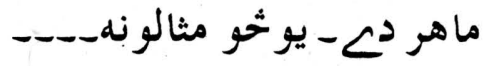

يانب هانب زرونه، لمبو كبنب لتار شوي تصوير ، د اوربنار سى، 


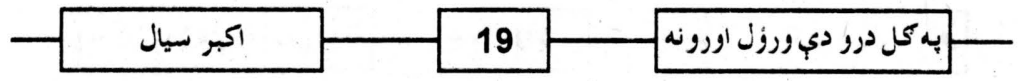

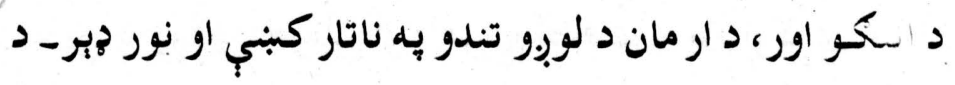
شعر دا اوإنه لفظونو ته نوب او واضحه معنب وربخبنىتصوير، تاثر او نوب فضا جوروىـ دا د هفئ د تجربب او فن

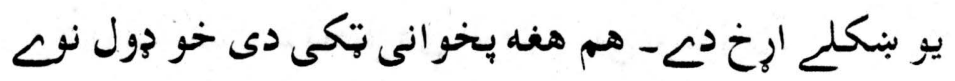
دم- سيال د لفظونو سره دغسي لوبي كوى او يه دغه لوبوكبني د ساده تبكو نه خوبِي خوجب؛ خبري رابر سبره كوبى وايى

ه - سيال دي د تولب دنيا سيال جوروى دا بهي تصوير دي به كمال جوروى

د"سيال" يه تجكى كبنب يب د تجنيس د صنعت يه زورخو مره اثر هيداكرك دع - خيل قام د دنيا سره برابرول غو إرى خو خبره د تصوير يبش كوى

او جب د زوند د كشالو يه اوجو او تاؤ زيلو مبرو كبني اوحي شو نلدي درو مى نو يه اعتماد حُحى او حو صله لرى د د بيان دي انداز دا خبره ثخو مره اسانه او موثرهكري دهـ ه نور به لا خحومره يه ما سر كرحوب

بس دع اسمانه را تر غاره وزه 


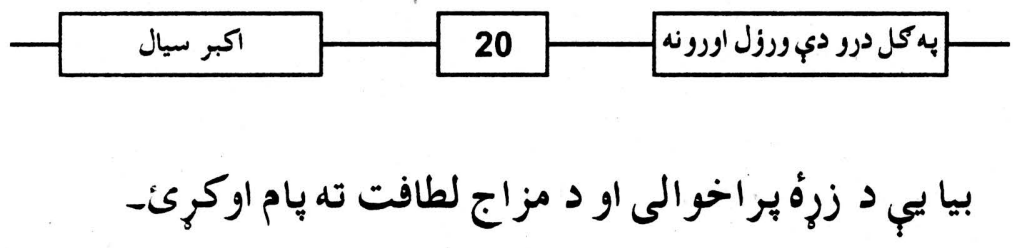

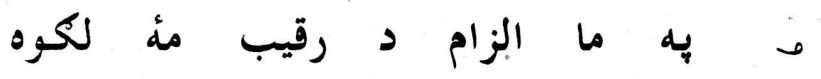

يه بل بـ كمانه رأره

او دب نزاكت او د تخيل دب الوت ته يب اوكورىئ-

, سياله زما د زنب خال شه اشنا

شين د خندا نه را تر غاره وزه

د سيال تول كلام د تشُبيهاتو،استعارو، كنايو او

د نورو صنائعو او بدائعو نه ذيك دم - هم يه خوند خوبر هم

يه شخنه ستركمه بورهـ د شاعرى عمارت خو يه دربو ردو و لار

وى- اول فكر او موادـ يعنب خبرهـ ترثخو تجب سرى سره د

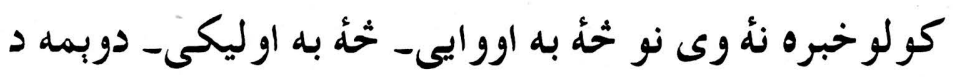

خبري كولو يا بل ته د رسولو د ياره بيان جورولـ دلته د زبي

او د تبكو جون او ترتيب وركولو هنر يُكار دبح- او دربم يه

داسي طريقه دا تبكى د بيان به مزى كبنب يبرل هب بيان خوند ناك شى، زرهُ رابنكونكم شى شلى دله تشبيها،

استعاري او د بيان د نورو صنعتونو او بدائعو ضرورت

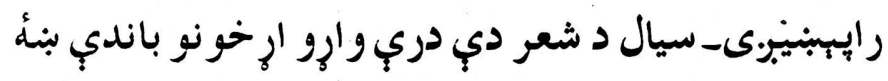




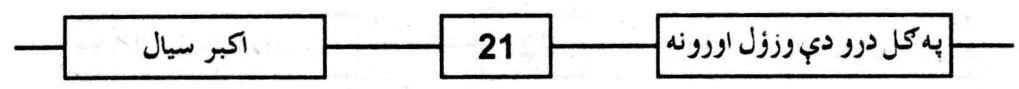

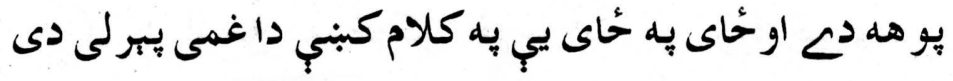
يو ثخونموني--

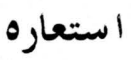

ه - كئ بنكلو راله تول عمر يه داركره زندكى د زركو زركو ستركو نه مي حار كره زندكى

ه يو كلاب جانان له اوتخنوه ستركي يسرليه مسكيتوب ته مب زرة كيبرى

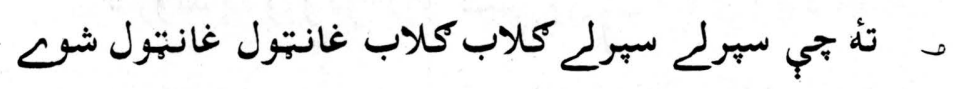

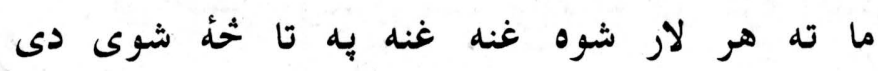

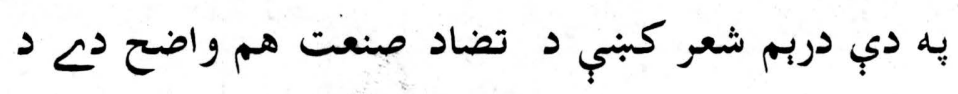
كحلاب او غانتول يه مقابله كبنب غنهتجنيس :- كله يولفظ به شعر كبنب دوه حُله يه دوو معنو كبنب راو ستل_ كله يو لفظ راورل او بيا وريسب داسب تتك راورل تب دورو مبى تتكى سره ديو يازياتو حرفونو لكولو نه جور وى لكه د "اور" او "اور اوركى" يا "لونكى" اوني "لونكينه" 


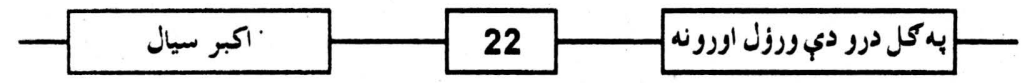

ــ د ازغو به "خوكو خوب ته مب زرة كيبرى

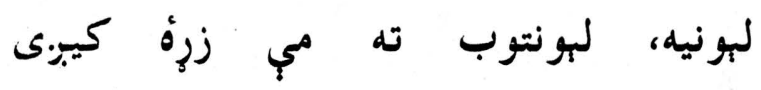
هـ د فطرت به كلدرو كبني، د جنت به منارو كبنب

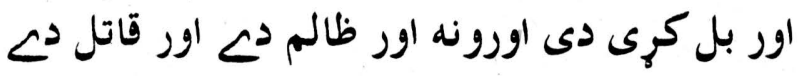

هـ رنكونه د سبرلى دكل غوتى د مخ نه جور كره

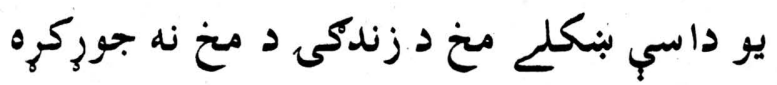

ه د زوند به وروكو لارو كبني ورك شوي وم د خحانه يو حسن زوند يرست راله به لار كره زندكى لئ

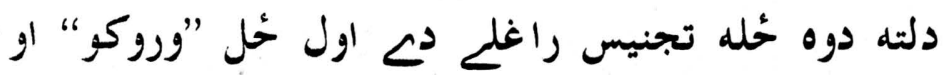

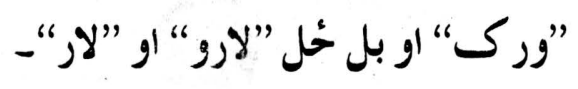

هـ د تمامي دنيا بنكلى بكبنب اوسى

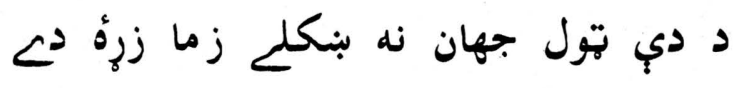

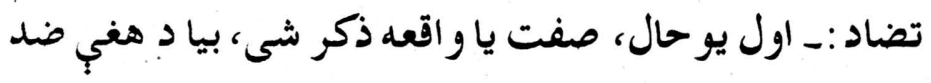

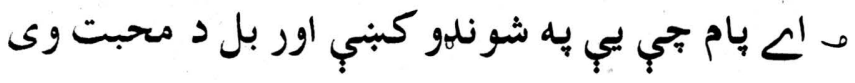

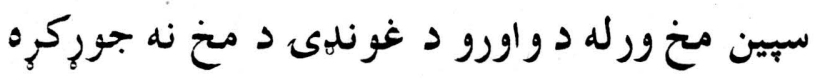




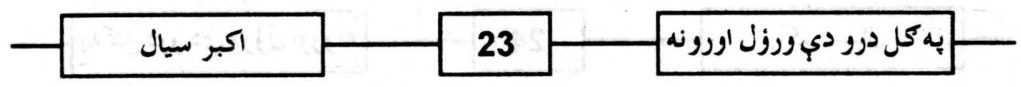

تلميح :- يوب تاريخى و اقعب ته اشارهـ

زهٔ د دي دور د ديزيد سلامى كفر كنم

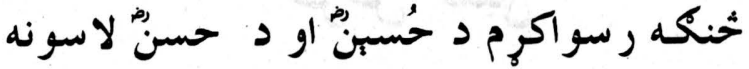

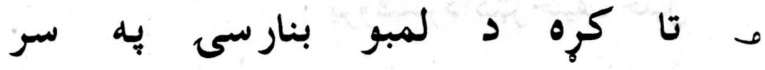

زهٔ - دب .هم جانانه بي نظير كرمه

هـ د دزؤوطن مي تول اوبئه اوبئه سبلاب سهلاب دي

به دي بانه به مي د دوبو ستركو نم، كم شى

د اكبر سيال يه زوند، فن اوشخصيت نورب هم دُبري خبري

كبدي شى- خولو ستو نكى زما نه زيات هوبنيار دى د هغdٔ د

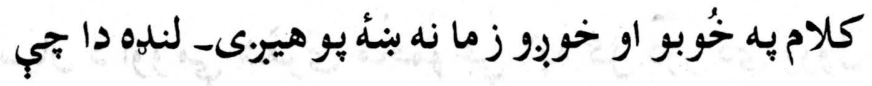

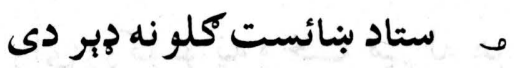

$$
\begin{aligned}
& \text { جولى مي تنكـه زهُ به كوم كوم تولو مله } \\
& \text { ممتاز على أسلام آباد }
\end{aligned}
$$




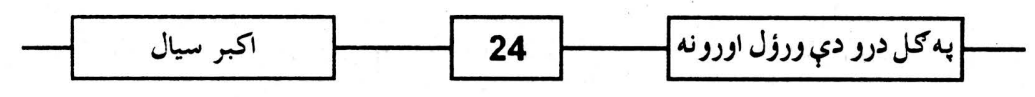

\section{عرض خليل}

بروفبسر إكتر حنيف خليل

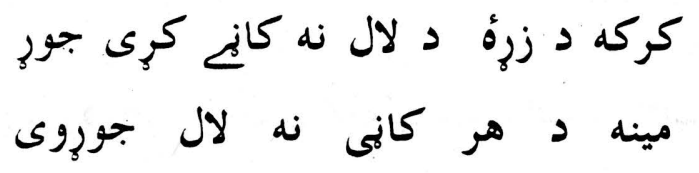

زمونب. د عصر د بالغ نظره، ويبن ضميره او د يو ربنتونى

حساس شاعر او يو خوبر او مينه ناكـ انسان بناغلى على

اكبر سيال د اوو مي شعرى مجموعي ”يه كل درو دي ورول

اورونه" به شاعرى د خيلي راب وركولو يَه وخت مب له هر

خحئ نه اول د هغئ يورتن شعر حُكه وليكلو جي د غه شعر نهُ يواحي د بنا غلى سيال د شاعرى مركز او محور ده بلكي

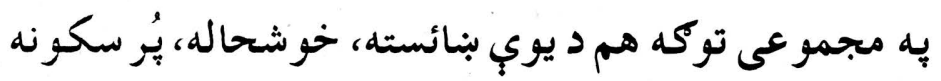
او مثالى انسانى معاشري د تشكيل او تولنيز جورِبنـت د باره د غه شعر بيخى د يو آئين او دستور درجه لرى خو به شرط د 


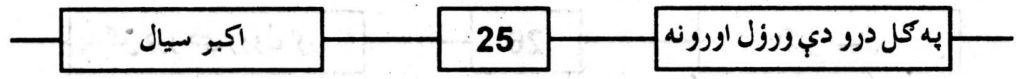

دي تب عملى اطلاق ئي وشى- دا حُكه وائم تجي انسان كئ پِه حصيح انسانى درجه غور وكرى نو د بناغلى سيال دذه راب د انسان د آفاقى، نفسياتى مزاج سره هم سمون خورى- كوم انسان تجي د د غه سطحب نه راتيتج شى نو هغه يه اصليت كبني د انسانى سطحي نه راكوز شى- حيكه زه د سيال د دي مجمو عي به شاعرى د هم د غه شعر به رنا كبنب خحُٔ وئيل غوارم خو له دي نه مخكبنب دا هم وئيل غوارم جي د بناغلى سيال توله شاعرى د هغؤ د شخصيت يوه داسب آينه ده جي د هغله د كردار، مزاج، اخلاقو، مينب؛ درد او جذباتو صفا تصوير پيكبني ليده شى- مغربى

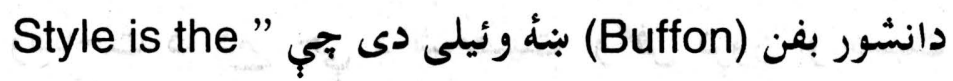
"man itself يه فن كبنب د هغه د شخصيت كرؤ ورهٔ به غبر محسوس طريقه حُاب مو مى- مونب. كئ د سيال د شاعرى يه تناظر

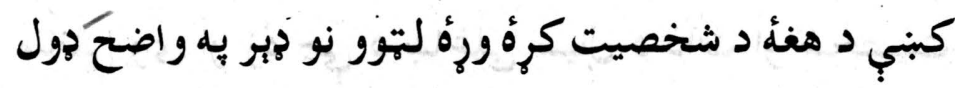
راته د هغله شاعرى د هر قسمه دورنكى او منافقت نه باكه 


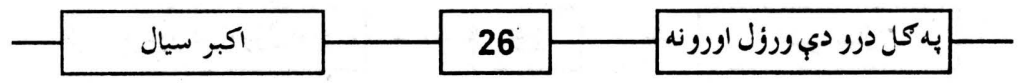

بنكارى- سيال دير خوبر انسان ده - د مينب سره ئي دُبره مينه ده او د كركي نه دِّره كركه كوى- او بيا كله جي هغه دو خيل د غه خوبج، مينه ناك، دردمند او حساس شخصيت اظهار د خيل هنر او شعر يه ذريعه كوى او خبل اولس او قام ته د د غه افاقى او يه صحيح معنو انسانى جذبي د خهيلولو خو است كوى نو كويا هغه او د هغهُ شاعرى د بِبنتون اولس د ياره د يو بي مثاله او لازواله سر مائب حبثيت اختياروى-

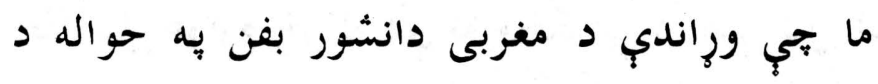

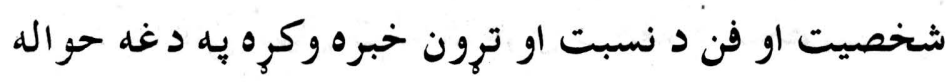
يو وضاحت كول غوارم او بيا به د بناغلى سيال د دب مجموعب د شاعرى يه اسلوب او انداز خو خبري كوموضاحت دا ده جي د شخصيت او فن ترون او نسبت يواحي د هغو فنكارانو به حواله ثخركنديدل شى كوم فنكاران تي د خيل فن اوهنر سره مخلص وى- جا تي د د خيل فن او هنر آئينه د دورنكى او دروغ بيانى د دورو نه ياكه ساتلب وى او زهُ جي د بناغلى سيال د ذات او شخصيت ثخ مره مشاهده لرم نو بي د ثحُ مخ ملازي ووئيل شم تجي د 


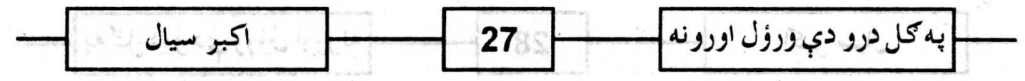

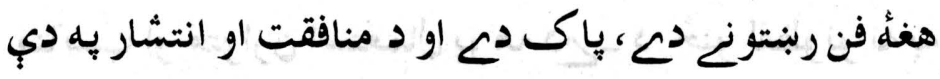

$$
\text { دوركبني محترم او.مقدس دم - }
$$

يه شاعرى كبني اسلوب هنبر اهميت لرى- كوم شاعر جي خيل اسلوب او خيل انداز لرى هغه زونده ياتب كيبرى

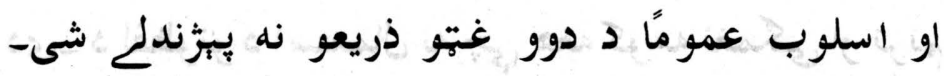
صورى او معنوى، يا فنى او فكرى يا يه اسانو تّكو كبنب به ووائم تجي يو د شاعر خيال او فكر وى او دوئم د هغئ فنى جوربنت يا د د غه خيال او فكر لفظى جامه د سيال د شاعرى يه حقله زهٔوئيلِ شم جي د اسلوب يه

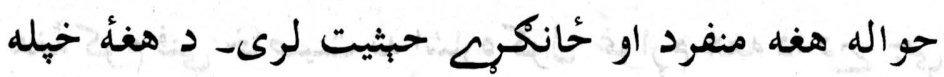
شاعر انه لار ده، خهيل رنكى، خيل آهنك او خهيله ادا دهـ د

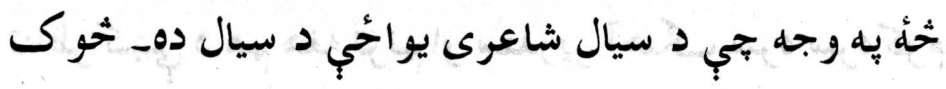
جي بلز هم د شعر شناسى مزاج لرى نو هغه به د سيال شعر

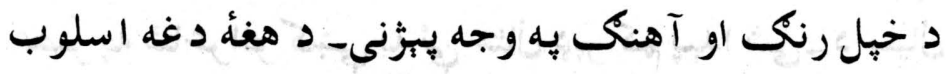
جي د كو مو عناصرو نه رغونه موندلي ده د هغي به صورى او فنى عناصرو كبني يو ثخو ته اشاره كول غو ارجم-د نسيال د شاعرى زبه دُبره سو جه ، خوبره او فطرى ده هغه د لفظونو يه 
مناسب او متوازن استغمال يوهل ده ـ د حُحنو لفظونو نه يه خصو صى او به غبر شعورى توكى زيات كار اخلى لكه سندري، شور، بنكُى، سنكـر، مستى، امن، لمبي، اور، تصوير او تصور و غبره د سيال د شاعرى مخصوص تورى دى- د لفظونو د استعمال نه جي هغه كو مه نغمككى او ترنم يبدا كوى هغه هم د سيال خيله برخه دهـ د دغه ترنم او نغمكى عطا ده جي هغه يه يبنتو كبني د سندري ليكلو

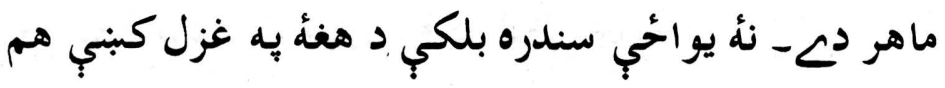
يو زبردست سندريز آهنك موجود وى خو زؤ جي دلته د هغؤ كوم فنى خاصيت ته اشاره كول غوارم هغه دادي تجب هغه د يبنتو اولسى صنف سندري ته د موجوده حالاتو يه تناظر كبني د هم هغه ترنم او سندريز آهنك سره سره كوم مقصديت او معنويت وركى ده ، زما يه خيال زمونب. د عصر به شاعر انو كبنب به ئي مثال دُبر كم يبدا شى- د سيال د شاعر انه اسلوب يه فنى خاصيتونو كبنب يو خاصيت د د هغdُ د قافيب او رديف استعمال هم ده - حُنب غزلب خو ئب دو مره يه كر انه قافيه كبنب ليكلى دى جب يه شعر كبنب د 


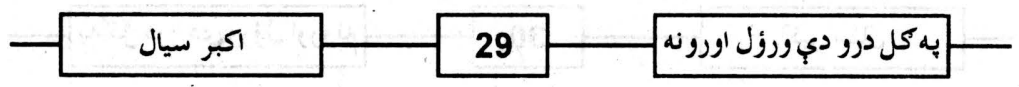

معنب ابلاغ ذِبر كر ان شى حمكه جي زمونبر د زياتو شاعر انو

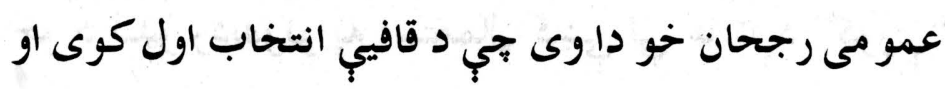
شعر يري بيا ليكى او دغسي هغه خيل فكر او خيله نظريه نهئ لرى بلكي خيال او نظريه ئي قافيب يسي كرحئ خو سيال

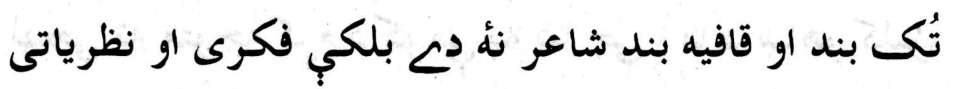

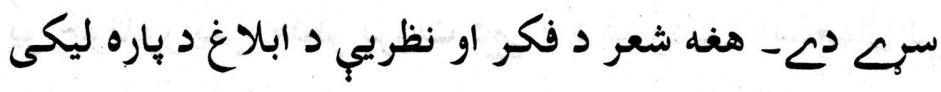

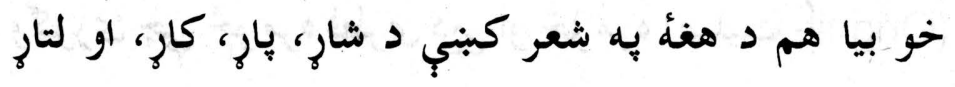

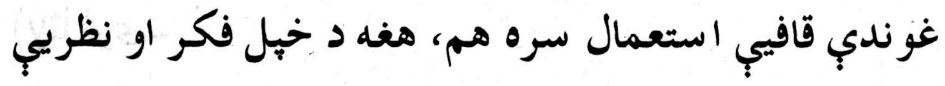

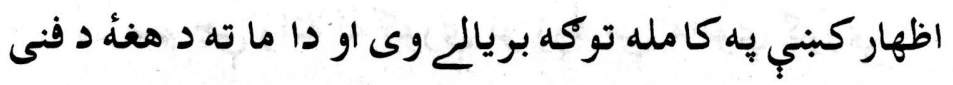
رياضت يو ثبوت بنكارى- رديفونه ئي هم د قافيوسره

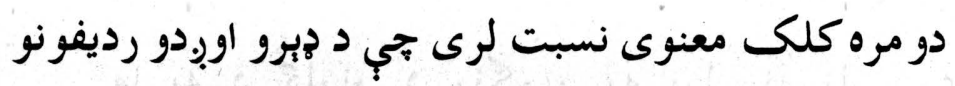

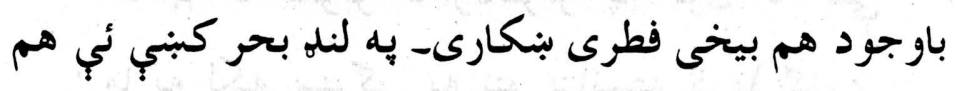

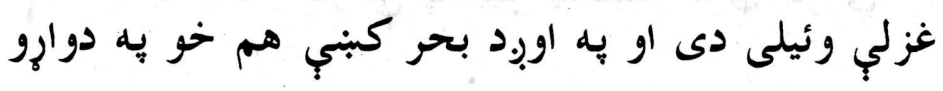

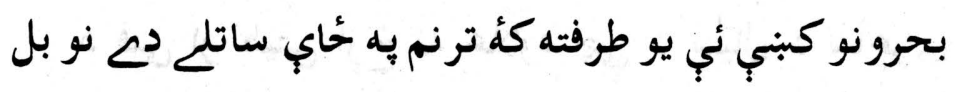

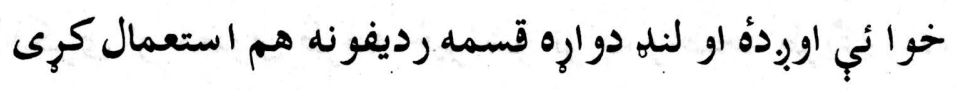
دى د اوبود رديف استعمال ئي خحو مره فطرى ده جئي وائى!

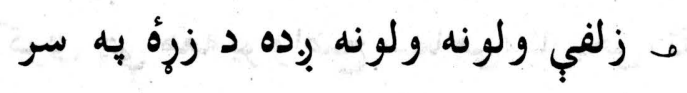




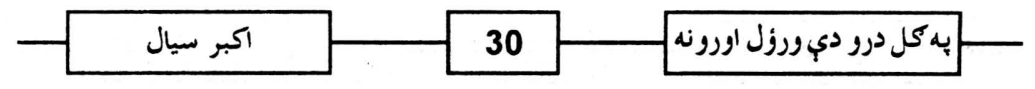

$$
\text { خوند كوى دامونه بِده د زرأه به سر }
$$

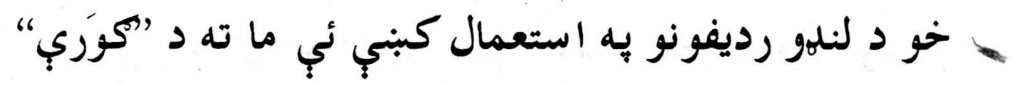
رديف دومره مزه راكره جي زه ئي يوحُل بيا زما سوجه دئه

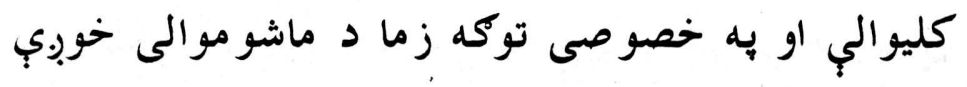

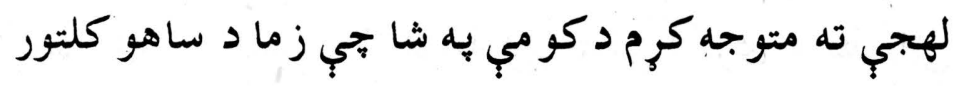
يو خوندور يس منظر يروت ده ده دوغه رديف استعمال ئب

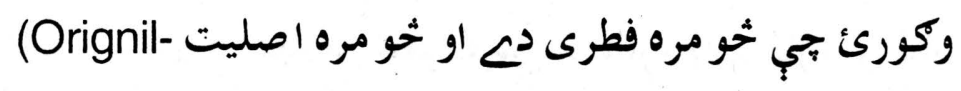

$$
\text { لرى ity) }
$$

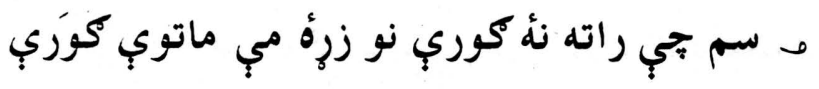

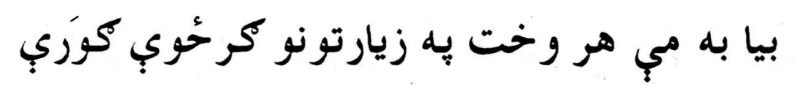

ما به د ككلونو د رنكونو يِه تول نهُ تلب

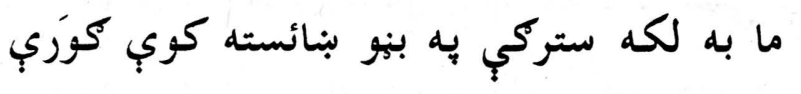

د فنى او هيتى إخخ نه علاوه جي د سيال د شاعرى فكرى او معنوى طرفته خير شو نو به واضحه طريقه راته نهاه

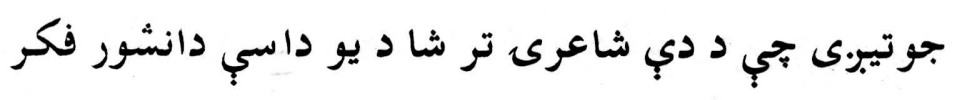

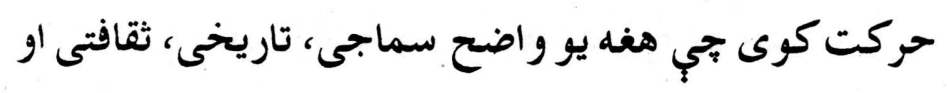




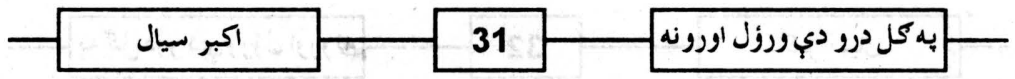

سياسى شعور لرى او ور سره د خيل يبنتون اولس د نفسياتى

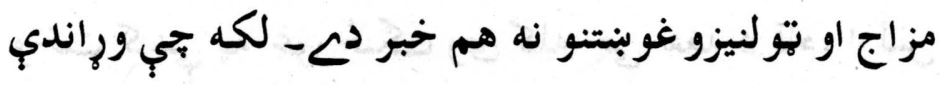

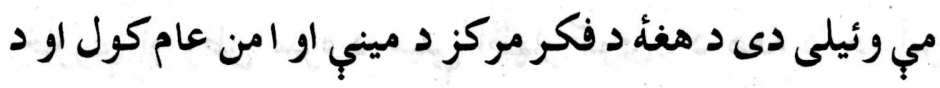

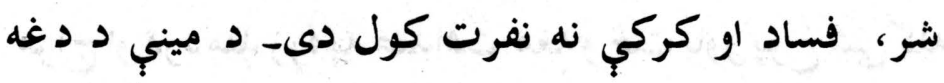

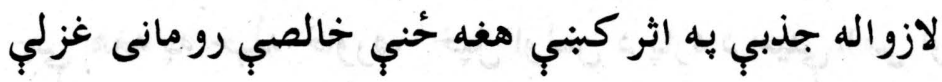

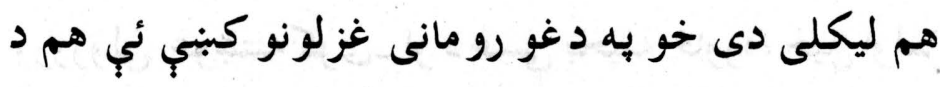

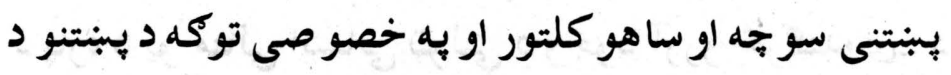
كليوال رنكى تصوير به ديره بنائسته طريقه بيش كئه

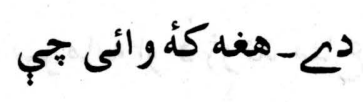

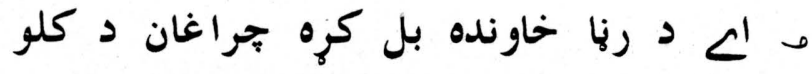

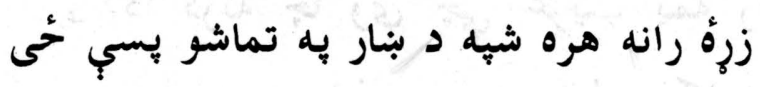

يه بنجازى راشه دـ كلى كوشخي اوشرنكوه

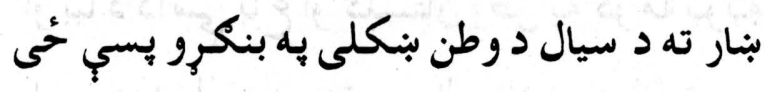

نو د د غه فكر تر شا هم هاغه مشاهده اوعملى تجربه

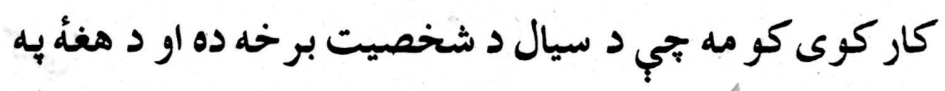




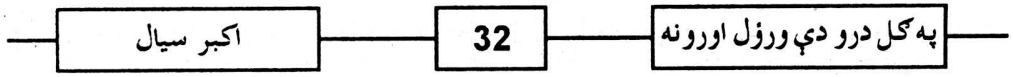

روح او وينه كبنب ككله دهـ خو د هغغُ د مينب جذبه به هغه وخت كبني يه غورحنك وى كله بجي هغه د قام، اولس، خاورب او وطن سره د مينب اظهار كوى- د مغله د حساس مز اج او درد مند زرهة يه صداقت هغه وخت باور يوخ شى كله جي هغه بـه خهله خاوره، خيل اولس د ياره د مينب،امن او ورورولى غوبنتنه كوى- او دغسي يخخيله خاوره، خيل اولس

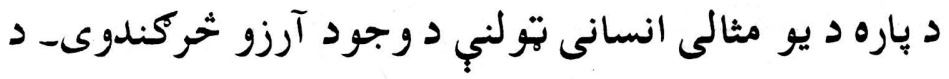
هغهُ يه وطن او اولس كبني تجي انتشار ووى نو هغه به خنكى نهٔ درديب.ى حئكه جي د هغئ خو توله سر مايه او د زوند متاع هم د غهوطن او اولس ده حُكه خو وائى بجي

هـ .دا درته يا وب نجي غريب يمه زه وطن مب باغ دع او اولس كلونه

او بيا د داسي باغ او كلستان وطن بـ كو مه تتوته بجي شر وى، اور وى او لمبي وى نو سيال باندي به ثحئ تبربب.ى حئه جي د خيل كملستان وطن ذره ذره خو هغه خيل لبمهٔ او بانئ. 


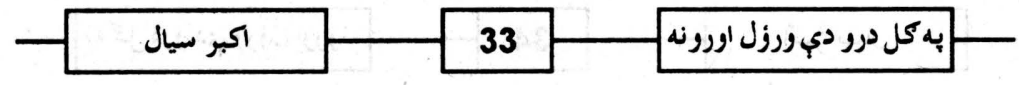

هـ يجبنور سوزى كئ وانه مي سوزى لكه جي ستركي او بانئه مي سوزى

بِه سيال د بنبتونخوا هره سيمه كرانه دهـ د هري سيمي وكرى د بنبتون قام متي دى او د هري سيمي د درد

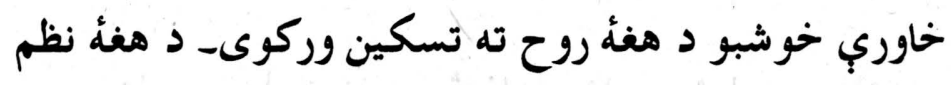

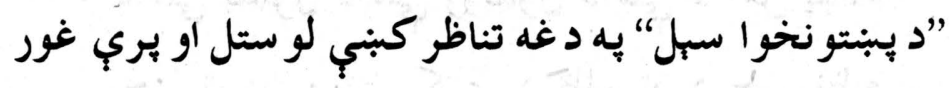

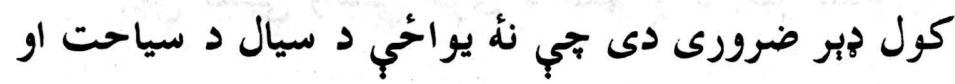

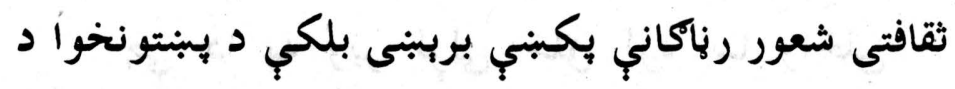

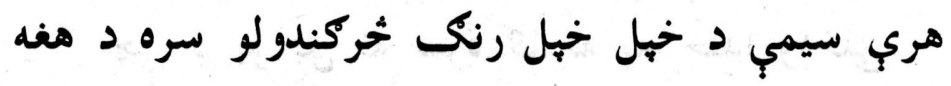

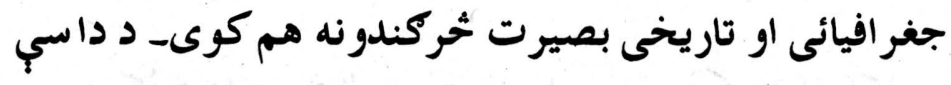

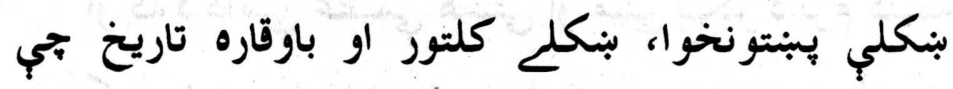

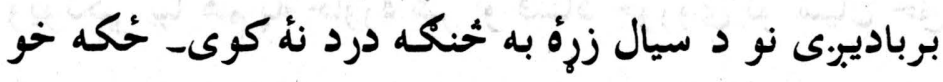

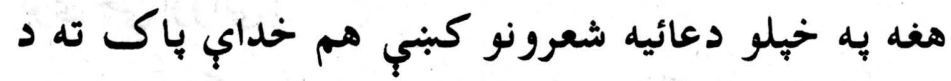
وّبري مايو سى به كبفيت كبنب خو است كوى جي ه مودي وشوي د عرش نه تماشه كوي د فرش مائ يه خدايه دا وطن مي د خدائى د مخ نه جورئه 


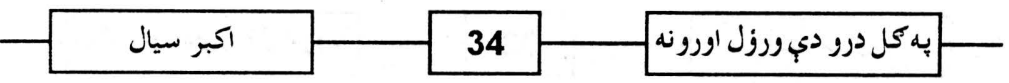

او خبل عظيم يبغمبر، د مينب، ورورولى، امن او ايثار

لازو اله هستى خيل خوبٍ نبى وا سطه هم وركوى اوو ائى!

هـ زما دي وران وطن له هم د زوندون زبرح راوره

زما اولس تي كرى اباد د بدلون زئح راوره

داسي بدلون داسي زوندون داسب د امن يُغام

جي تسنب و سنب كرى د ظلم او د جبر نظام

جي دا يه وير لهلى خلق لب.ه سا واخلى جي د يو بل نه سرؤ كلونه يه خندا واخلى

او كئ د داسب عظيمي هستى او ميني يبكر د نوم كليمه ويونكى بيا هم يه خاوره شر او فساد خوروى نو سيال حقى

$$
\text { لرى تجب اووائى ! }
$$

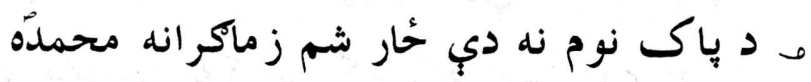
خو ستا د امتيانو نه هم كور لري هم كور د سيال د يو يو شعر تجزيه كئكوم نو خبره رانه 


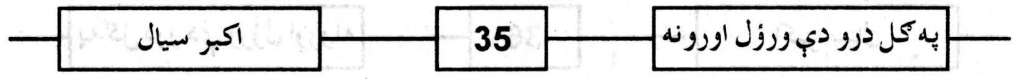

اوبجديبزى خو به اختصار سره به اووائم بجي ما د هغله د شاعرى د كو مي مركزى نقطب يعنب د مينب سره مينه او كركي نه كركه كولو وضاحت سره خبره شروع كري وه لاتر او سه يه هم د غه تشريح او وضاحت كبني روان يم- د هغئه د دي مجموعي د شاعرى حُني نورو ارِخونو ته كُٔ اشاره كول غوارم نو وبه وائم جي هغه د خهلو اتلانو تذكره هم كوى او كارنا مب، قربانى او خدمات ئي هم ستائىـــ هغه كئ د يبنتون وكرى د مسافرى قائل نهُ هم دح خو بيا هم د هغؤ روح او كلتورى مزاج مغه د خيلو ملكرو يه مسافرى شاعرانه اظهار ته مجبوروى - هغه كئ يخخل اوبرد علمى او ادبى زوند كبني كله نعت ليكلو ته نهٔ ؤه متوجه شوع خو ولب به دي مجمو عه كبنب ئي يو داسي نعت ليكلم ده بجي يو خوائي كئ د حضورّ د مينب او امن مثالونه ورواندي كرى دى نو بل خوائي د شر او فساد خورونكو ته به خبلو ناوره منصوبو د. سوت موقعه هم وركري دهـ هغئ كئ د ظالم، جابر، غاصب او سر مايه دار غندنه كوى نو ورسره د غريب، مفلس، محكوم او مظلوم اولس دياره يه معاشره كبني يو باوقاره 


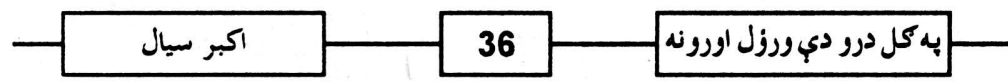

مقام هم غواريى او د غسب بِه محنت، مز دورى او خوارى يهه حقه ويار او الفتخار كوى او دغسي د غبر انسانى معاشرب

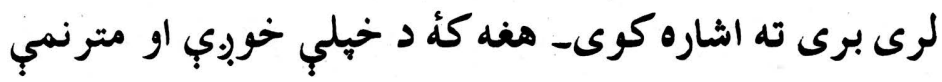
شاعرى او سندريزه آهنك له مخه د بِنتو هنر مندانو يه

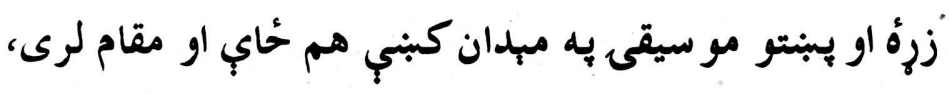
نو ور سره د دانشُوري او علمى طبقي او حلقب توجه هم حئان ته راكاربى او داسي د دي هر شحئ به نتيجه كبنب هغه د يوب خوشحاله، د امن او سكون، مينب او انسانيت علمبرداره تولني د تشكيل آرزو او ارمان لرى او د د غه ارمان او آرزو

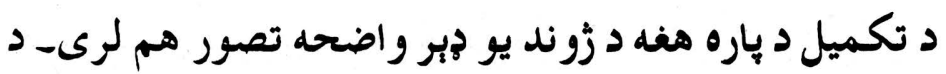
زوند داسي تصور جي به هغب كبنب حركت، حرارت،

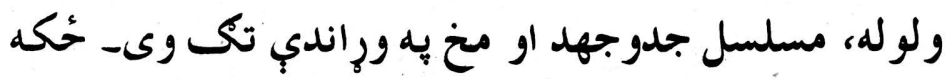
خو هغه يواحي د تقدير ليك ته يه قلاره نهٔ كبنبنى بلكي د خهل مقصد او مرام د حصول او خيل منزل ته د رسبدو د. هاره هر وخت نوب تدبير كوى-

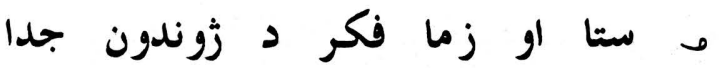
تُٔ ئي به تقدير زهٔ به تدبير كرمه 


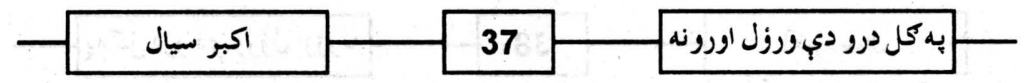

د داسي فكر ترجمانه شاعرى به حقله به زهٔ بنه به وثوق

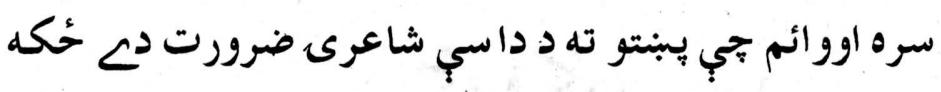
د بناغلى اكبر سيال دا مجموعه د بِبنتو به شعرى سر مايه

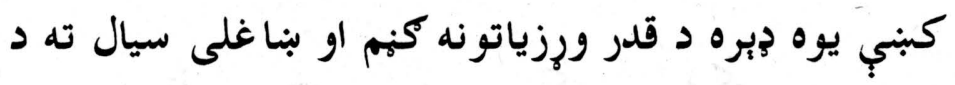
مباركى سره سره اولس ته هم زبك وركوم او د سيال د رون او خحلاند فكر او زوندى تخيل د باره د نبكو هيلو اظهار كوم-

حنيف خليل

قايداعظم يونيور ستتى اسلام اباد

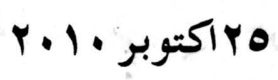




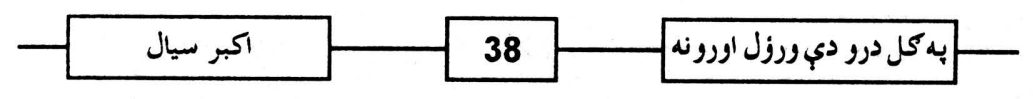

\section{كُن فيكُون}

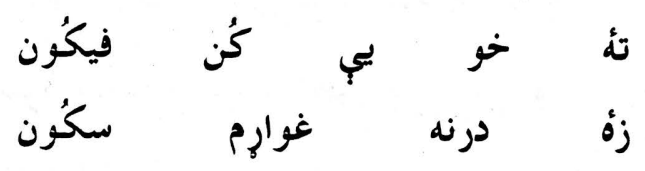

دا ناقلار زُوندون زما كره به قلاره ربه

زمادلداره ربه

تهٔ

نمكه

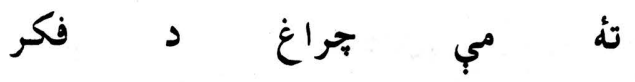

ته

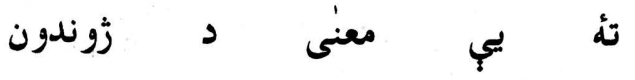

زه

ما دي محروم نهُ كيك دحسن دكلزاره ربه

زما دلداره ربه

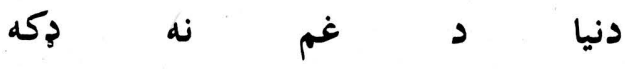

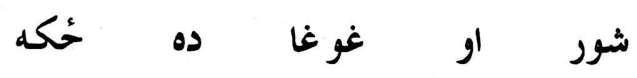




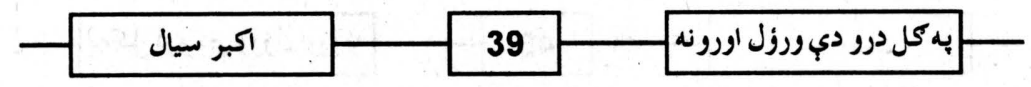

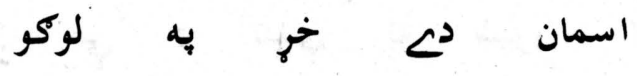

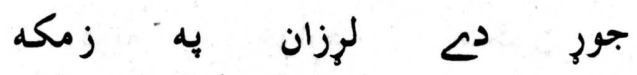

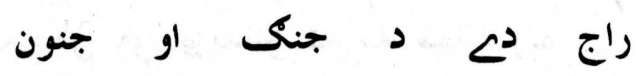

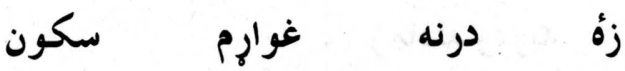

دجنك بر ستولاس نيول غوارى سركاره ربه

زما دلداره ربه

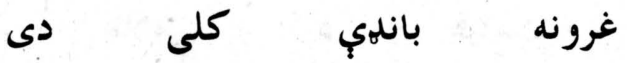

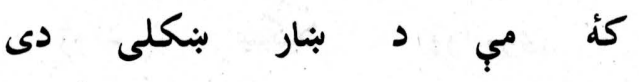

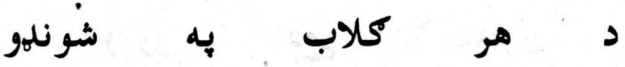

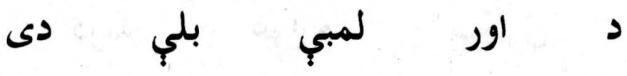

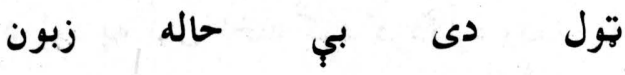

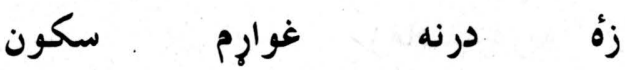

رنك مي د زوند خحانكي له راوره نوبهاره ربه

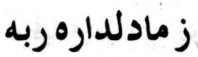

ملكونه

s?

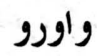

د

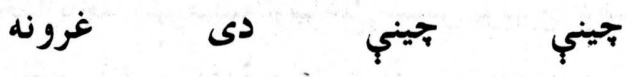

د إباسين

سيندونه

דيجي

דיָي 


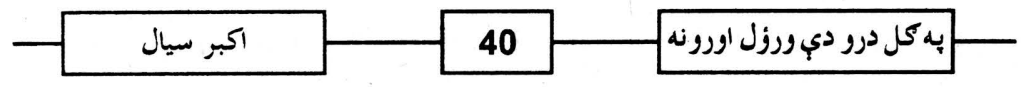

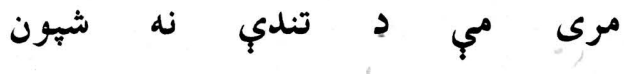

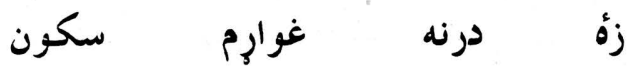

جنت وطن مب يزيدانو ته مئ سياره ربه

زم مادلدارهربه

ورانيب.ى

دنيا

سياله

ورانيبىى

يا

نن

قيامت

2

علامي

دى

ورانيبىى

بنكلا

زُوند

s

ببلتون

$c^{2}$

زورور

כָبر

سكون بنون

غوارم

درنه

ز

ظلم د زرهُ به نُول اخته كره كردكاره ربه

زمادلداره ربه

يادكهر نه :ـ داصوفيانه سندره به يكم مئى نــــــ د سالار ادبى تولني بونبرزبر انتظام

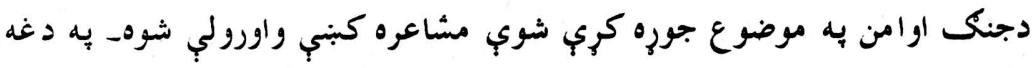

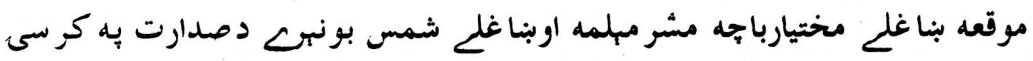

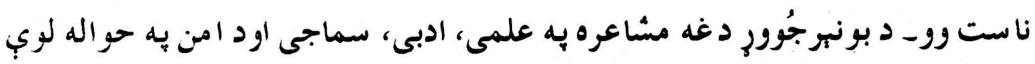

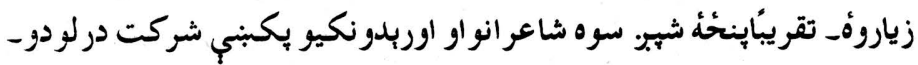




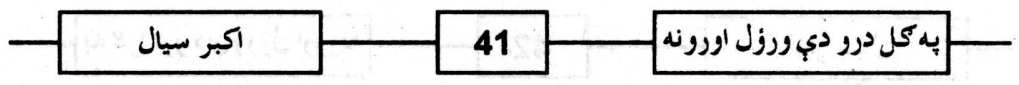

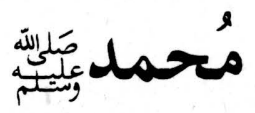

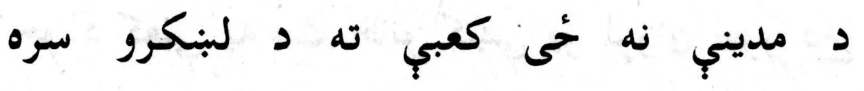

د سينو تُورو، د نهزو، غشو د زغرو سره

خو ستمكر غوندي مزاج د حكمران نهُ لرى جي كرِى دبنمن يه وينو سُور، دغه ارمان نهٔ لرى

هاغه يتيم هاغه مظلوم هاغه غابن ماتي سك هاغه د غبرو به نظر كبنب تجي وهُ پاتب سهر

هاغه سهب نن د طاقت او دبدبي نشان ده

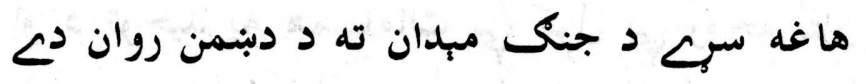

نه يجي به ستركو كبني غرور نه تكبر به زرهة كبنب

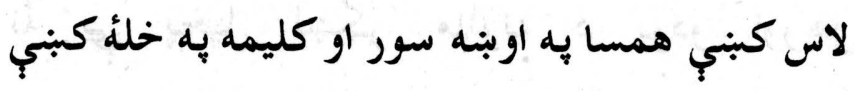
د مخ تحهره يمي د الله د نُور، د رحم دُكه

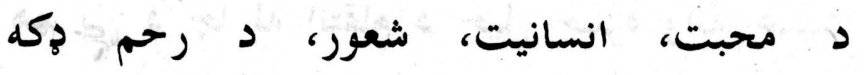




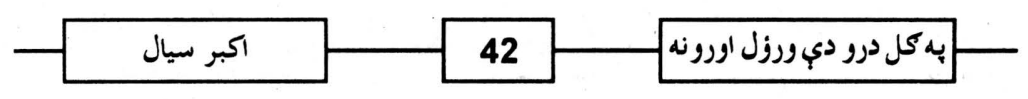

خو د كعبي به بت خانو كبني يو لرزان جور ديخ د بت برستو زرونه ريى سم طوفان جوري ديك

راغ او ودربد به كعبه كبني او اعلان يب اوكرو د مينب امن او انصاف يو خوبر اذان يب اوكرو

كئ جا يناه واخسته معاف ده د سُفيان به كور كبنب هم به جمات كبني به وى معاف هم هر انسان به كور كبني يو خحو د جبر او د جهل كانى كانى خدايان او د توحيد به همسامات يب كرل بي روحه بُتان

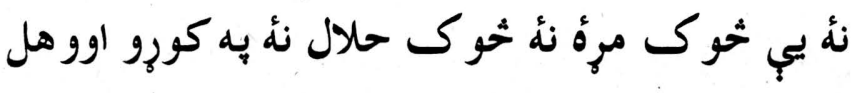

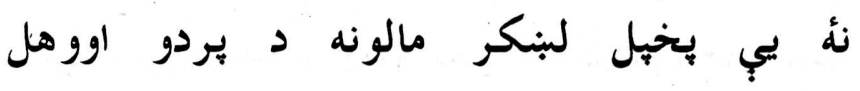

د يو ظالم د يو قاتل نوم يب به خلهُ وانهٔ غست

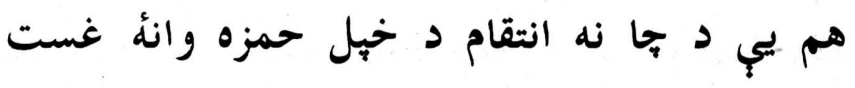




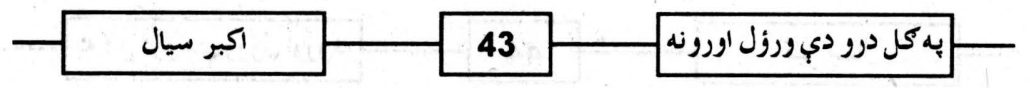

يورته اسمان ته به دعا وو كل ورين لاسونه د جا بِه وينو يجي ككر نهُ كرل حسِين لاسونه د مينب امن او انصاف جنلهه يجي يورته كرله د ظالمانو به خلاف جنده بورله نو لع د خداى عظيم انسانه معتبره نبى

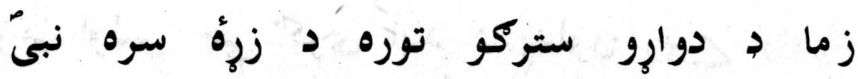

زما يه كل وطن كبني نن يو كربلا جوره ده هر خوا ماتم دح شور او جغي دى غو غا جوره ده

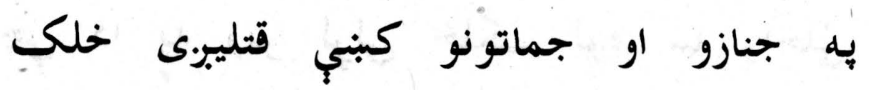

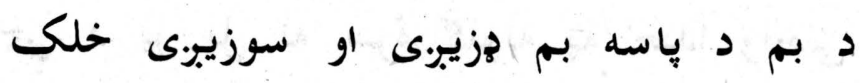

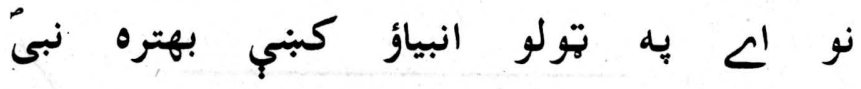

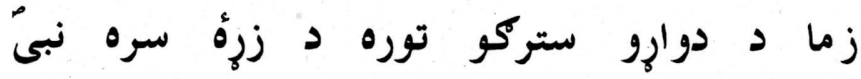


به 44

زما دي وران وطن له هم د زوندون زبك راوره

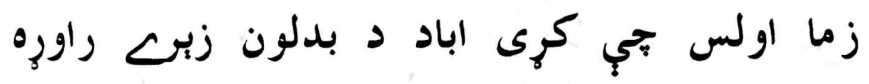

داسي بدلون داسي زوندون داسب د امن يبغام

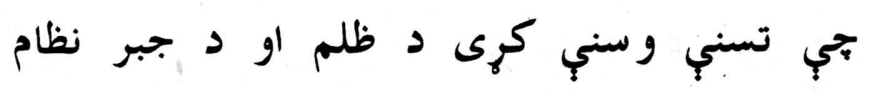

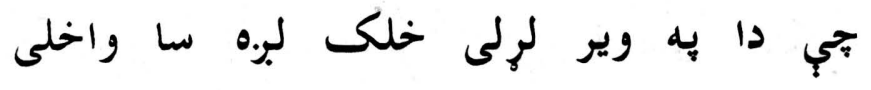
جي د يو بل نه سرة كلونه به خندا واخلى 


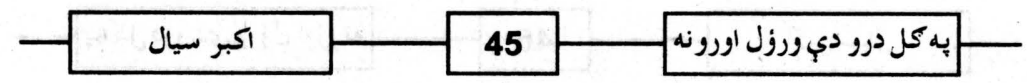

\section{0}

جور به وى بل خاى كبني طوفان تندر به مونبر بربوخى

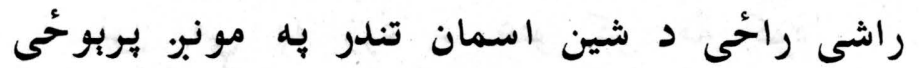

د بِنتونخوا د وطن بنكلو به زريا كبني اووي

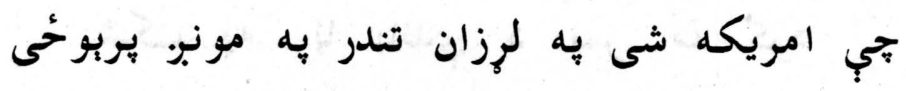
سبرلح جب راشى نو دبره شى د جانان به جبين

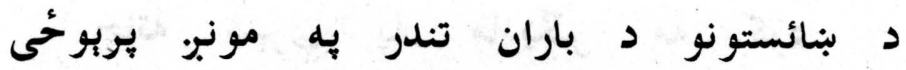
مونبره خو تول عمر دعا غوبنتي د رنكى او رنيا

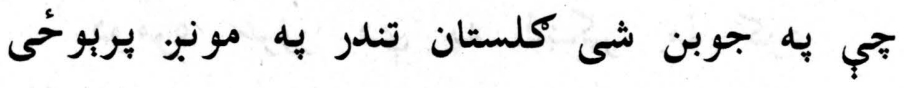

زرة مب د زلفو د وبهمو به تار ترى اوكئة نا

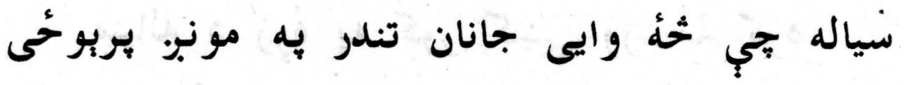




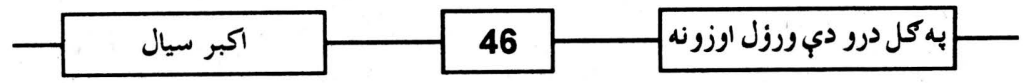

\section{0}

بانئ دي مئ برندوه شر مئ كوه

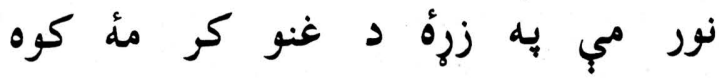

حُسن د زرةٌ به زمكه زوند جورئ

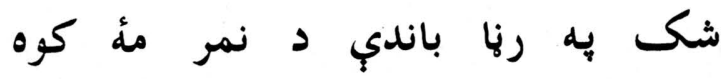

هسب نه زرونه به تيارو كبنب شى زوب

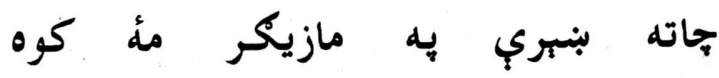

د وخت سيلى به دي تارتار كرى بانئ دومره غرور دي به لبنكر مهٔ كوه لهاه

نه جا له خجي او نهُ شحوى تاله راحُى سياله د زرةه به كور كبني ور مهٔ كوه 


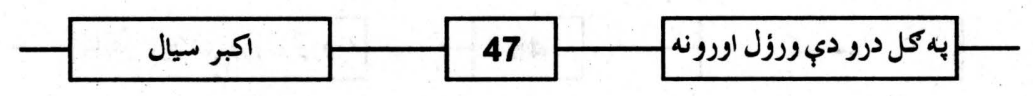

0

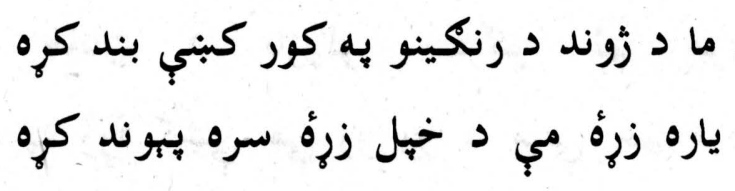

د هر مخ كاسه جي وكه د بنكلا كرم لويه خدايه ما د كل هسب شتئه مند كره

دروغزن دى جي تا نهُ وينى به زرهة كبنب جي د كانو يه كعبه باندي سوكند كره

د ناز هر قدم جي بِدي زما به زيرة ربدي ستمكره دا ستم دي خوم مره خوند كره

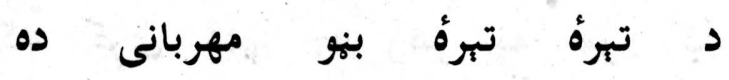
سيال د غنو غنو ستركو سره زوند كره 


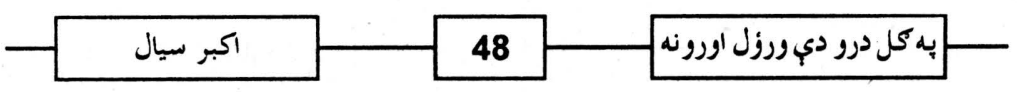

0

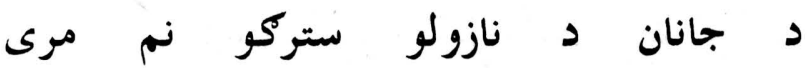
كئ به زئه كبنب مب رو رو د مينب غم مرى

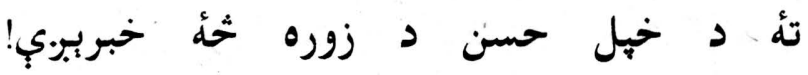
ستا د لاسه مئين زرونه جم پِه جِم مرى جي يجي شونلهي د د نسيم پِه باد ريبيرى

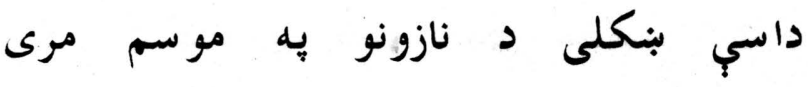

د جا زهة لكه سندان شى يه كعبه كبنب خحك د زرونو د حرمت به يو قسم مرى

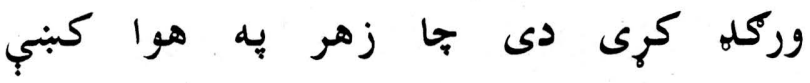

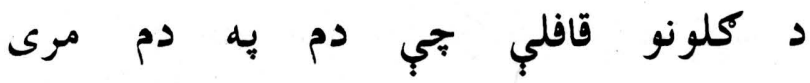




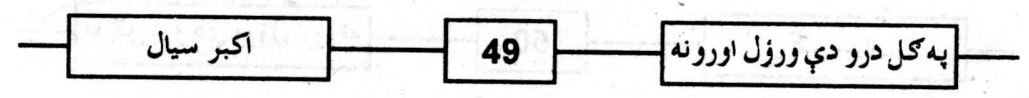

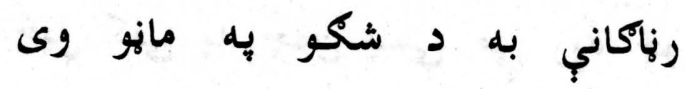

جراغونه به د غرونو د حرم مرى

د احساس وينب دي وجي شوي به تن كبنب

سياله حيكه خو شوخى ستا د قلم مرى 


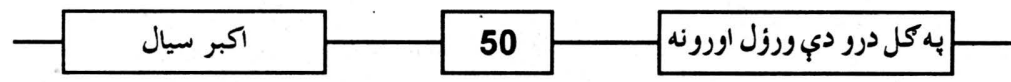

0

مسافر يم بِه وطن پيسب مب زرأ جوى

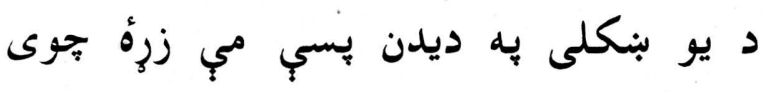

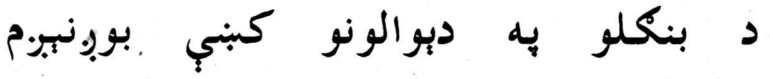

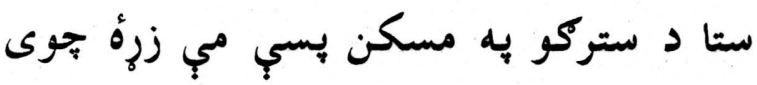

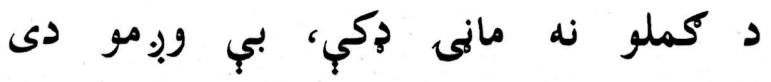

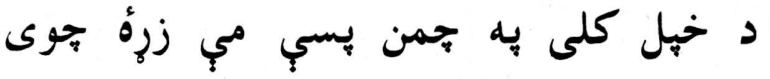

كانى كانى ستركي ديري دى به بنار كبنب

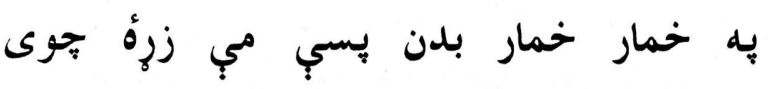

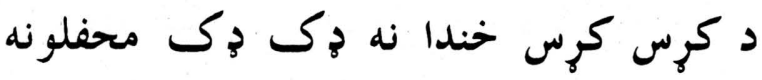
د حجري به انجمن بسب مب زرأ تحوى 
به بهل درو دي ورول اورونه

مور او بالار دى خوإندي رونه كئ اولاد دي د خهل كور يه هر يو تن بسب مي زرهُ جوى

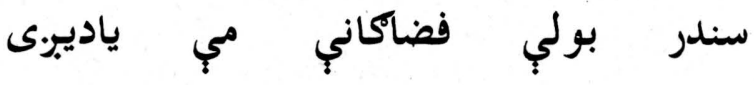

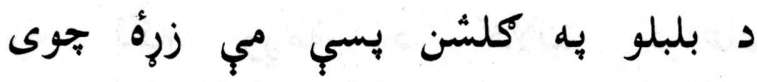

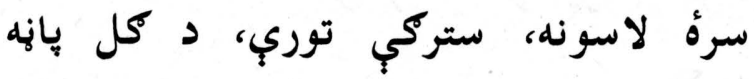

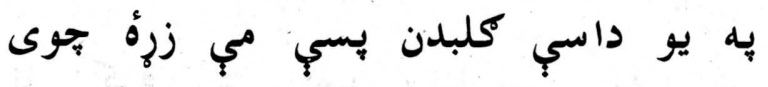

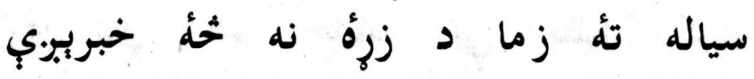
يه هو يار پيه هر مئين يسب مي زرٌ هوى

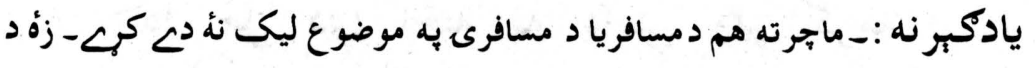
دغه تصور خلاف يم خُكه جي يجنتانه هجرت او مسافرى اونهُ كرى نوخئه به خورى

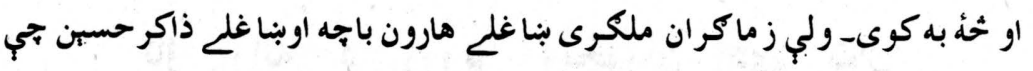

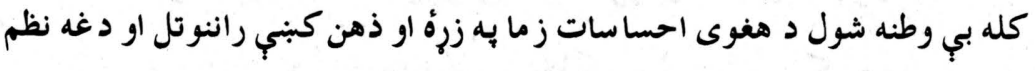
يا غزل اوليكل شُه 


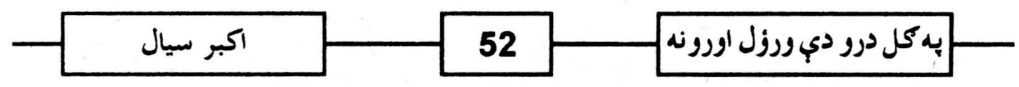

0

زلفي دي ول ول او كئ زنحئ كرمه

اووايه كوم خوب درله تصوير كرمه لهن

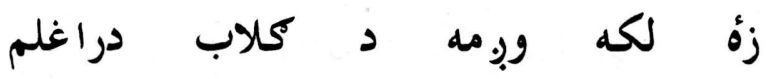

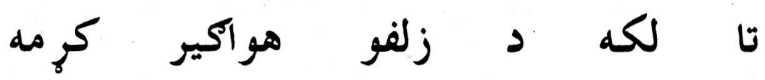

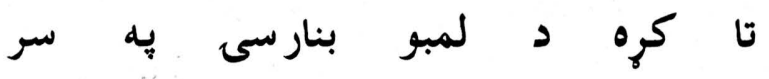

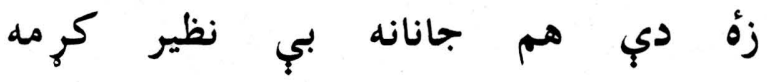

كاتتى مي به ستركو كبنب سم كانى شُو

دا حُل دي اخته به داسب وير كرمه

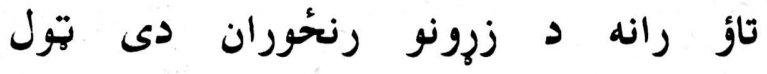

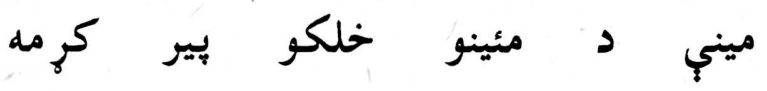




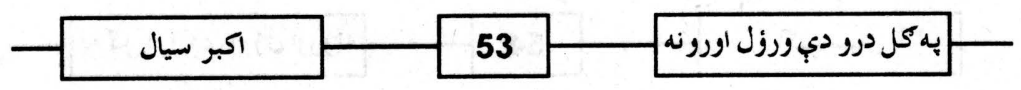

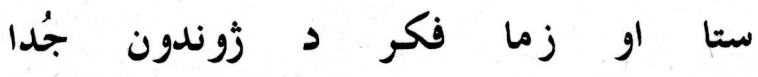

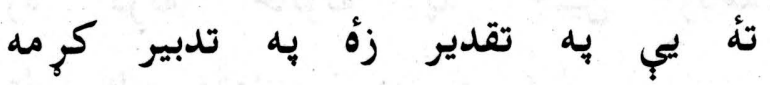
وخته به اسانه به مات لهم

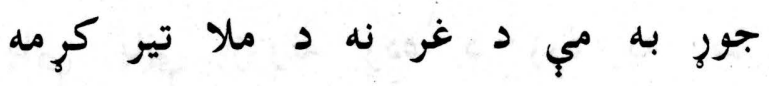

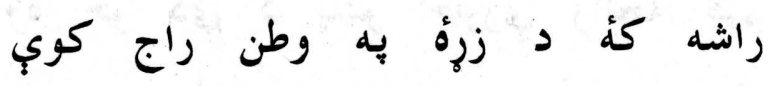
مخ به دي بادشاه او خال وزير كرمه

عشقه زه خو سيال د ماكنه نه وم

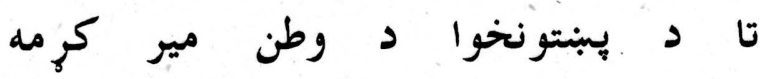




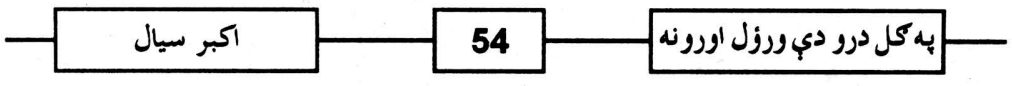

0

زلفب ولونه ولونه بوده د زرهة يه سر خوند كوى دامونه جوده د زره هيه سر

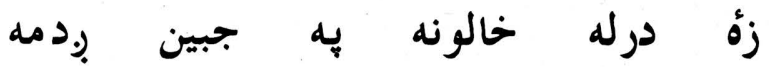

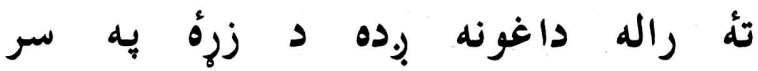

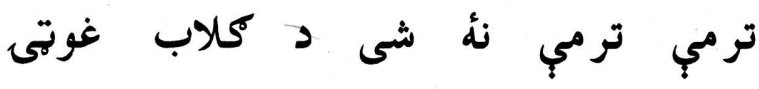

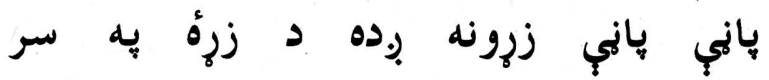

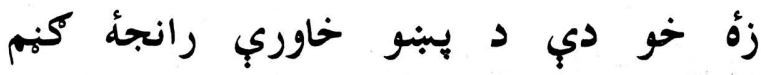

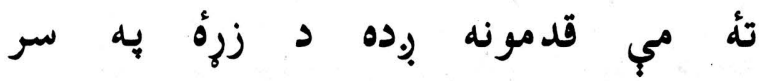
ستا دي وى قـم ستا به به.

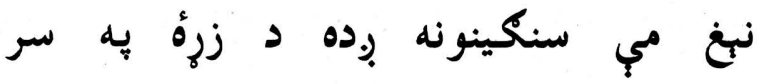

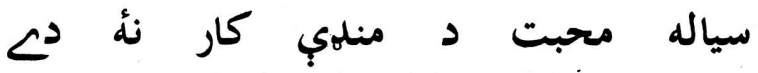

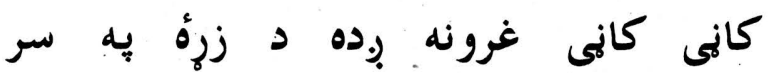




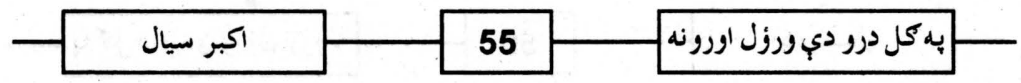

\section{0}

ستركي دب رندي دى! نهٔ يوهبرب تب دا ولب تئ

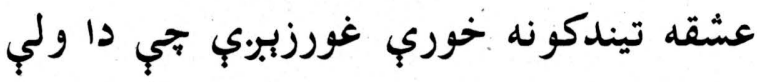

نهٔ جرته اور بل ده نهٔ لوكى شته به هوا كبنب

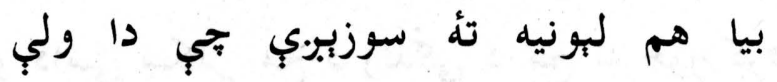

نهٔ يج اور يه شونلهو كبنب وى نهٔ يجي د نظر خمار

تهٔ د هر كاغذ به كل غولجبي تجي دا ولبي

زهٔ خو تصور يم كله يم او كله نهٔ يم

خامخا يه ما يسب رنحُبرب جي دي دا ولب

تول عمر د كوتي نه نيولِ دي خيل زئه ديك

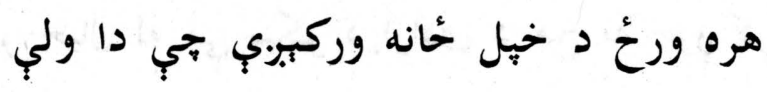

نه دي جرته غم شته نه مئين نهُ ليونغ يب

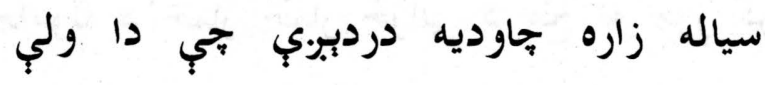




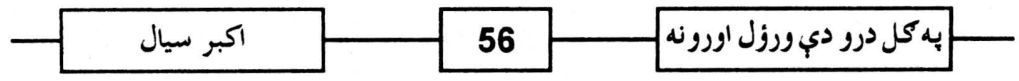

د ينبنتو نخو ا تصوير

رنككونه د سيرلى د كل غوتى د مخ نه جور كره

يو داسي بنكلٍ مخ د زندكى د مخ نه جور كره

راكوز شه د اسمان د سيارو او ستارو نه

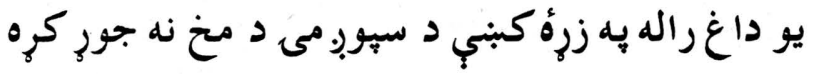

وحشت ده ، كربني كربنب، وينب وينب هر يو مخ ده

مسكح مسكح كلاب د بي وسى د مخ نه جور كره

د علم او هنر د تجربو د فن استاذه

يو خيال له مي يبكر د ازادى د مخ نه جور كره

دي تبو. تب.و ستركو له د حسن جادوكره

جامونه د خمار خمار حُوانى د مخ نه جوري كره 


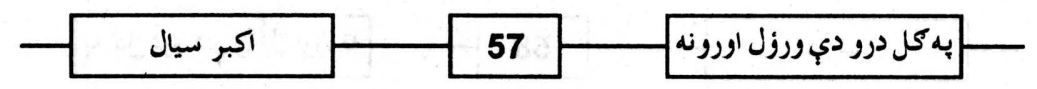

دا سري ملالي ستركي او نمكيني سبيني اوبنكي

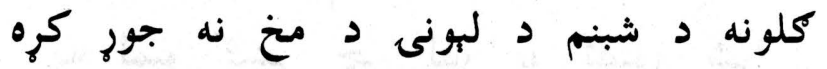

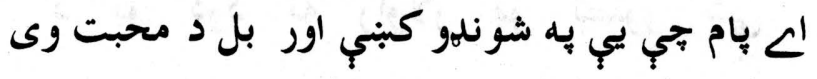

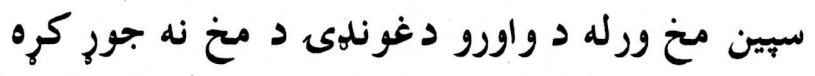
مودي اوشوب د عرش نه تماشه كوي د فرش

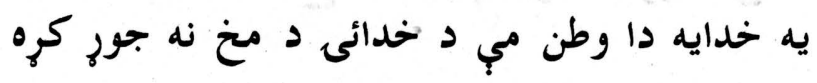
زهة خحأ اوكرم جي تنده مي به سيند هم نه ماتيبرى

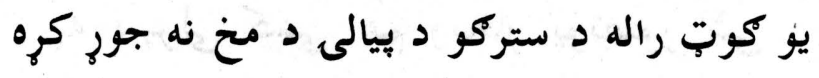
نرتوب ورله به زرئ كبني د زمرى غوندي يبدا كره

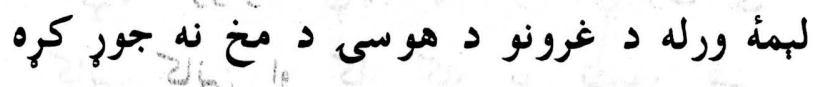
يه سياله لبنبوه كره يه جانانه مصوره د زوند د ناوي كور د غرشنى د ميخ نه بهوه كره 


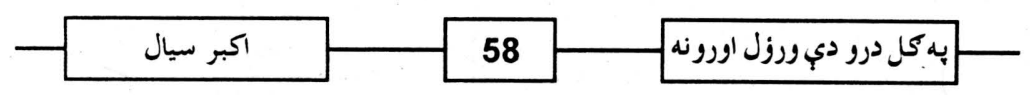

\section{0}

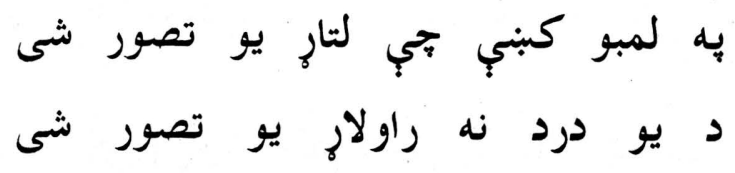

د كلونو خحانكي مله ريبه لَو لور شب د بنائيست كلم به شار يو تصور شى

د كملاب تصوير مي رنك يه وينو اوليد يه سيرلى كبني هم ويجار يوتصور شى جي يه غرونو كبني يبدا يه غار كبنب لوى شى

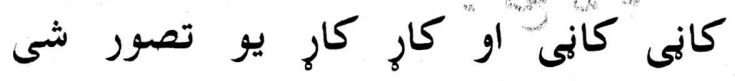
Fub

د اومان دو لوبْو تندو يه ناتار كبنب سياله ستا د شونلهو پيار يو تصور شى 


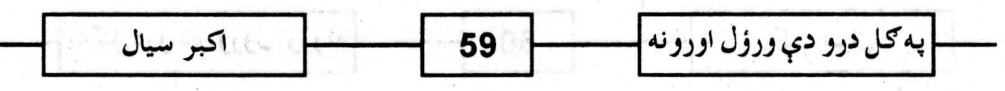

0

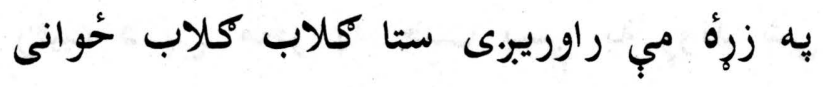

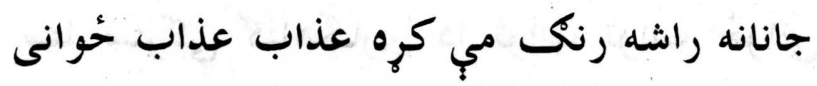

د حسن د خمار نه د بنو غبوب راتاؤ كره

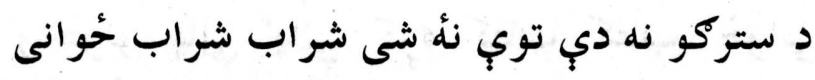

د ستركو يه كاسو كبنب يو خمار شى يه غورحنّك

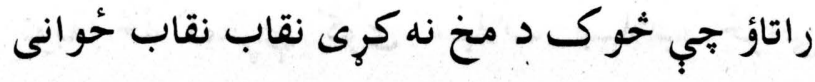

د غرونو د كستانو به جاؤدونو كبنب تتوكيبى تنكى تنكى كلونه او شباب شباب شيوانى

هو زرؤه بِه اوركبنب سوزى هر ارمان تيكه تيكهد ديح

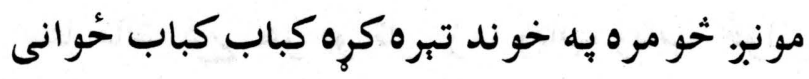




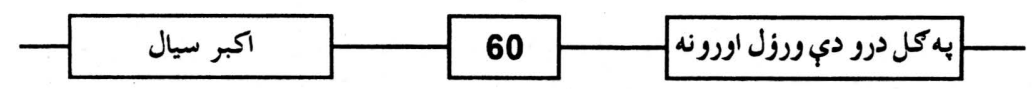

رقيبه د بى مخو بيه جنت بسي به روند شب

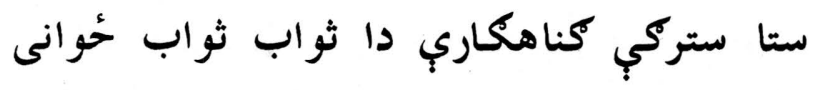

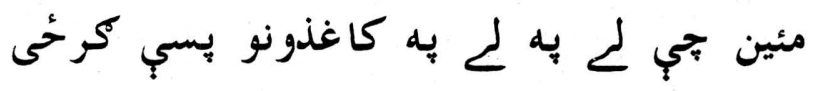

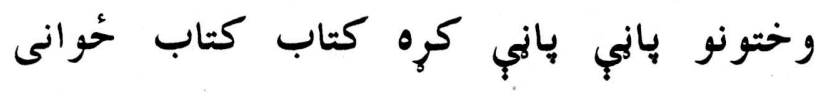

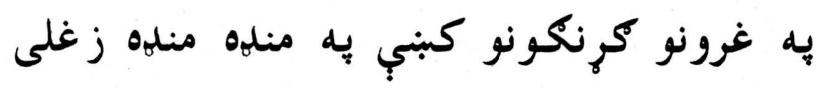

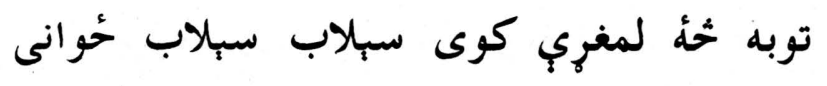

تاؤ كرك يجي بهونغ د خهبل حسن د لمبو نه

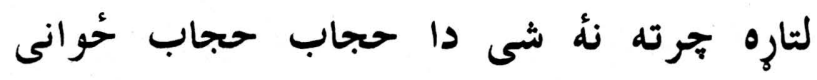

يه سياله لبونيه دا به تحئ كيبرى زئهيه

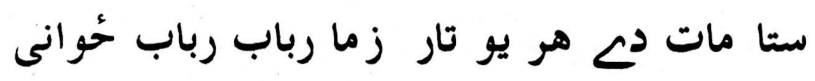




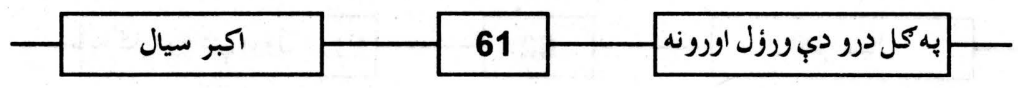

0

تا خو بند بِه بند تهلِ ده خيل زئه

ما يه موتى كبني نيولغ دي خهيل زئه

زما خُلهُ زما يه خهلو وينو سره ده

ما د سوخته نه جيجل ده خهل زئه

زؤ يو داسب جواركر د محبت يم

جي ماتول عمربائيلل ده خهيل زئه

ستا دستركو قاتلانو قصور نشته

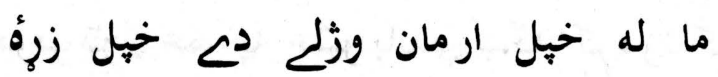

عاشقان بكبنب د سر اومال نه تهر شول

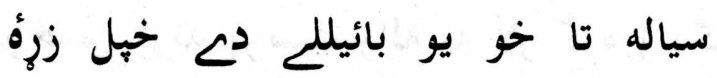




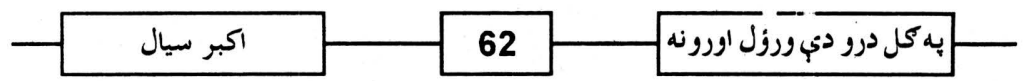

\section{0}

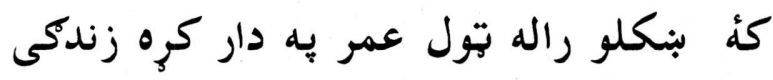

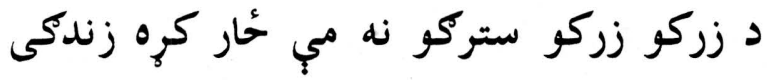

دا غرونه غرونه زلفي او نازك نازك كلونه

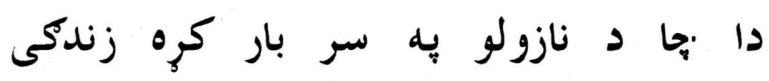

تش حسن ته كتل جي هم كَناه كنى د ستركو دي خنى خنى خلكو خو ازار كره زندكى

د ستركو د بنو نه بغير نئ كيبرى روندون مونب. تول عمر به غشو باندي بنكار كره زندكى ندي دروند به وركو لارو كبني ورك شقه وم د حمانه

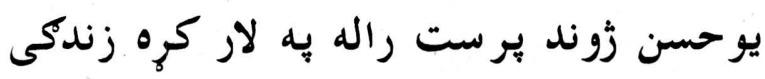




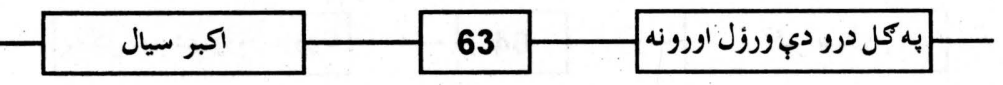

ما تبوب تبرب خاورب كري د زرهُ به وينو رنكى

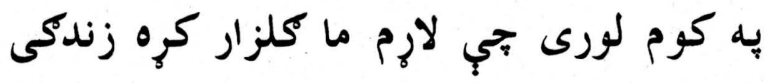

تندع د جا به در كبنب سُولول لويه كناه ده د خبل زهره به حرم كبني مب اختيار كره زندكى بهى

ما وب تجي تله به جور كري د كمثحو نه زنحُيرونه يه سياله تا به زلفو كبنب تار تار كره زندكى لهي 
به كمل درو دي ورؤل اورونه

0

ستا د زلفو د جنجال نه مب توبه كره د نرو شحانكو د تَال نه مب توبه كره

مبارك دي شه ما اوكندلب ستركي مسلمانه د جمال نه مي توبه كره

نور د زلفو به تار نهُ كنلهم زخمونه د ربنبمو د هر خيال نه مب توبه كره

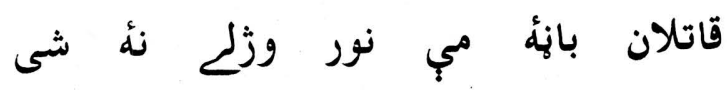
ستا د ستركو د وصال نه مي توبه كره

خحنكه شين ده د خندا نه به لمبو كبنب ستا د زني د مست خال نه مي توبه كره 


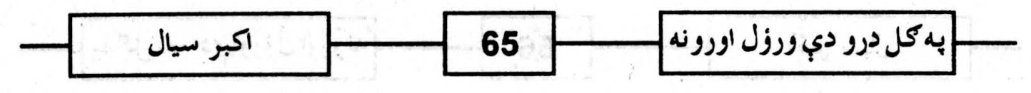

د توبك شيبلى حي جكمه ترشملب ورى د دي هسي رنكى ننكيال نه مي توبه كره تونه

دو زول زوندون يب راته اور او وطن كور كرو

دا باكل خو نهُ د حان او نهٔ د بل دي بنه شوه بنه شوه جي د سيال نه مي توبه كره 


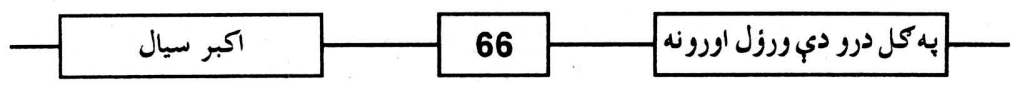

0

جي به كومه كوخهه تلع زما زئه

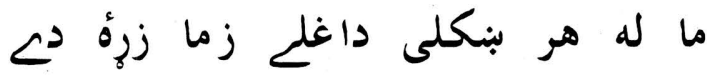

نازولى خحأه خبر دى تجب درد خحٔه دي

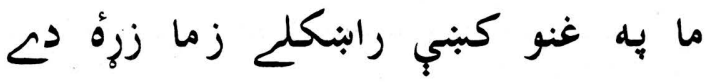

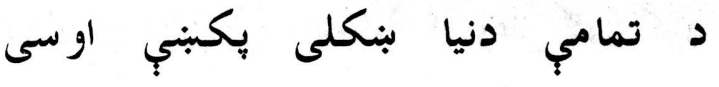

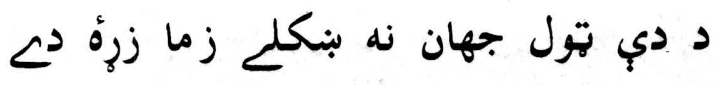

ستا د ستركو د خمار د سيند به غاره تل د اوبنكو جام كوتلغ زما زرة دئ

جي احساس مب زُوبلوى او رنحُحوى مب

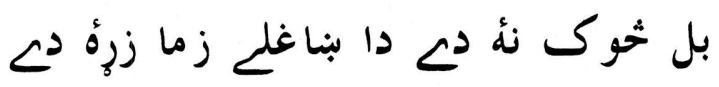




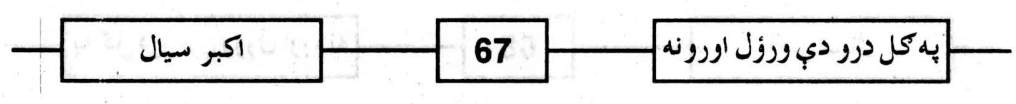

يه بي زروؤ خلكو واخلئ كؤ بكار وى

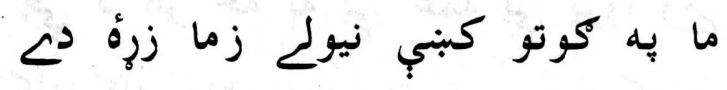
سياله ما درله كملاب يه مينه دركرو كبرزنه تا مرورئل 


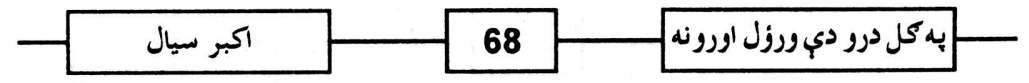

\section{0}

د ازغو به خحوكو خوب ته مي زرئ كيبرى

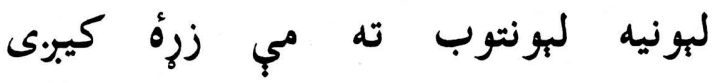

يو ككلاب جانان له اوتخنوه ستركي بسرليه مسكيتوب ته مي زرؤ كيبرى

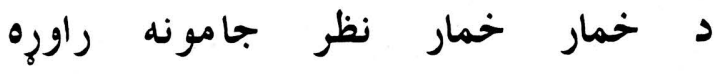
ما نشه كره سريتوب ته مي زئه كيبرى

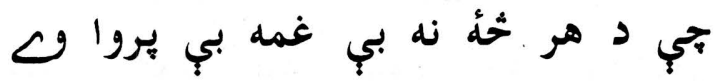

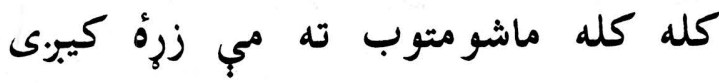

ما ببكاه به خوب كبني يار له غبرهه وركره

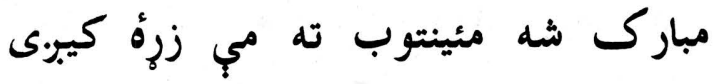

سر نجي حار كرم له وطنه زيره د ياره سياله داسي يو نرتوب ته مي زيرة كيرى 


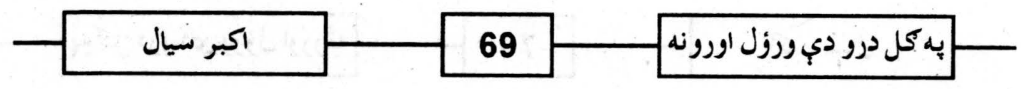

\section{سندره}

د درد او مينب د وفا يو تصور يوره دي

جانانه زةٌ دي پيه تصوير خحة كوم

زما د زرهة تجكور له دا يو تصور يوره ديك

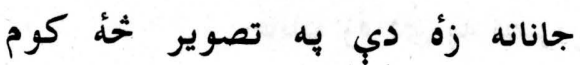

د درد او مينب د وفا تصور

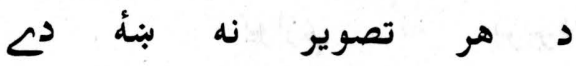

جي مب به زره كبنب اخلى سا تصور

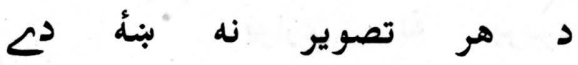

جي هم بينا وى هم كويا تصور

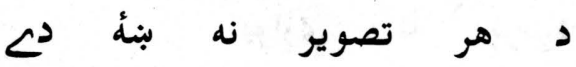

جي مب زونده ساتى اشنا يو تصور بوره دي

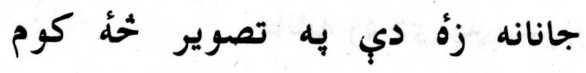




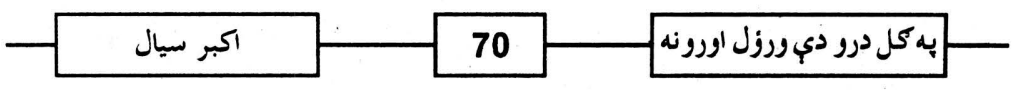

داسي تصوير تجي يب يه شونلو كبنب شور

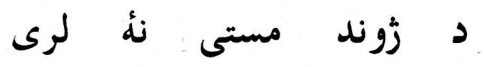

داسب تصوير بجي يب هיه ستركو كبنب اور

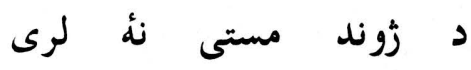

داسي تصوير جب يب به زلفو كبنب زور

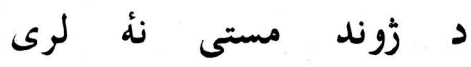

د كاغذى تصوير نه ستا يو تصور يوره دي

جانانه زة دي يه تصوير خحُ كوم

ستا تصور راسره مل مدام

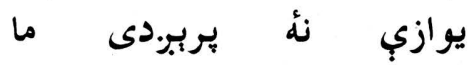

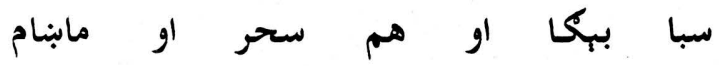
يوازي

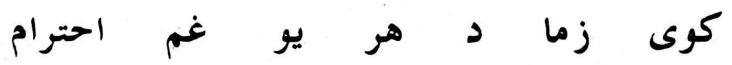
يوازي

ماله دي دومره بي بها يو تصور يوره جانانه زهة دي به تصويرخئ كوم 
به

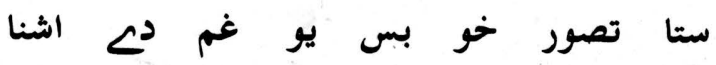
تل مي به زرة كبني اوسى

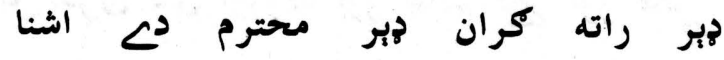
تل مب به زهر كبني اوسى

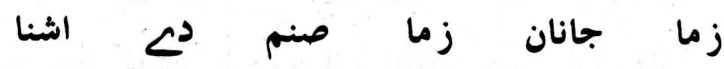
تل مي به زهرة كبنب اوسى

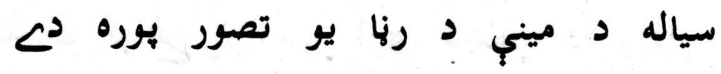
جانانه زهُ دي به تصوير حُهُ كرم 


\section{-}

\section{0}

اور ته مئ نيسئ كلونه اور ظالم ده اور قاتل دي

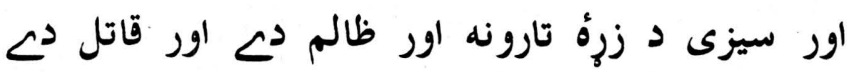

د خوبانو سيين مخونه پيه نكريزو سؤ لاسونه

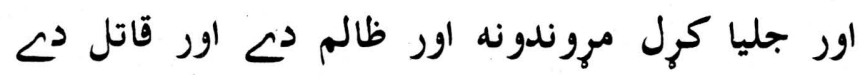

د فطرت به كل درو كبني د جنت به منارو كبنب.

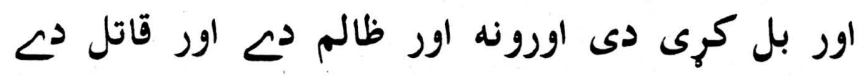

اور قيامت ده اور ذلت دِ اور دبنمن د سريتوب ده يه اور مئ كوئ نازونه اور ظالم ده اور قاتل دي

د تهذيب نوغ اوباسى لوي دبنمن د ارتقاء دي

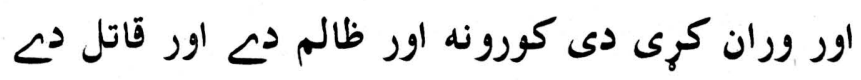

اور يو سُور اتش فشان ده اور لاوه ده اور بارود دى

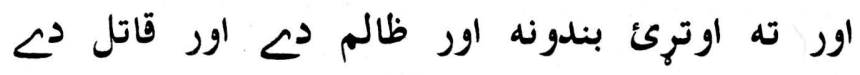




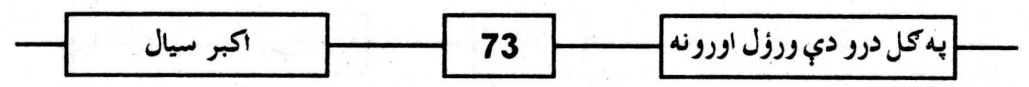

اور يو درد ده اور لمبي دى اور عذاب عذاب دوزخدي

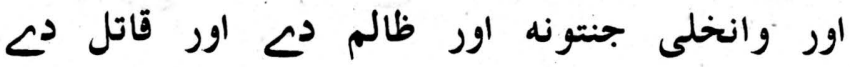

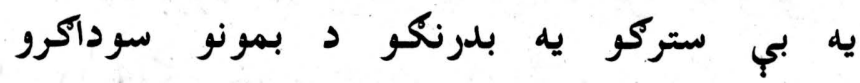
بند كرئ بند كرئ دا جنكونه اور ظالم ديه اور قاتل ديه

كور او كلى ته رانهُ شى خحئ تجي مر يب كرو به غرؤكبني

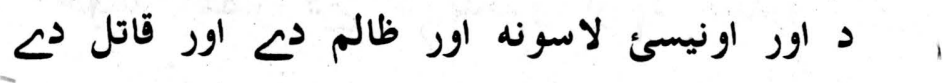

سياله اور وحشت وحشت، بربريت ده، تشدد ده

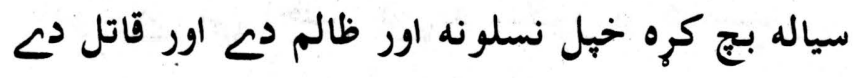




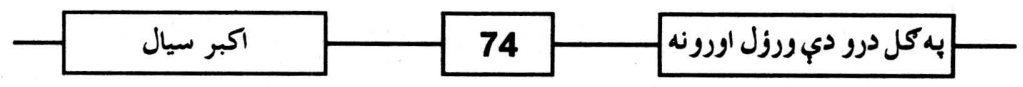

\section{0}

خاموشه هر يوبنار ده د بنككرو او د سندرو

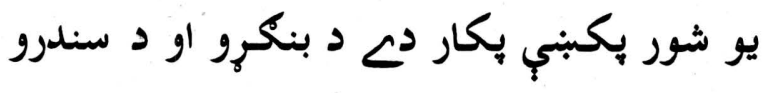
راياشحئ لبونو د زوند مستى يكبني ببدا كرئ

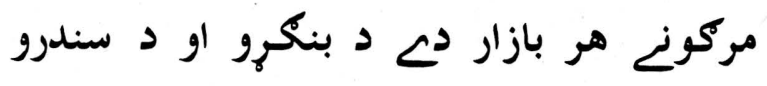

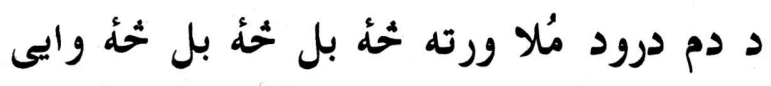
دا خلك خو بيمار ده د بنكيرو او د سندرو د مينب او د امن جنج تيار ده بس درحمه

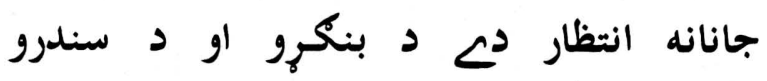
جانانه ستا رضا ده ماتوي كئ جوروي يي دركيك مي اختيار ده د بنكيرو او د سندرو

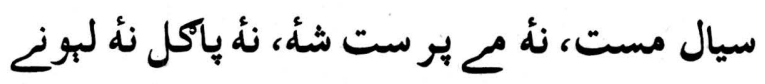

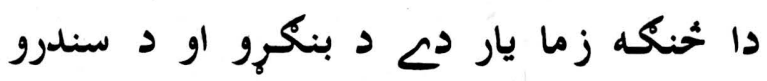




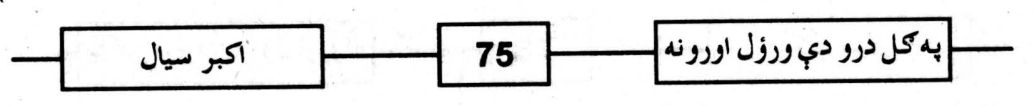

سندره

شونلهب كره مسكى كله

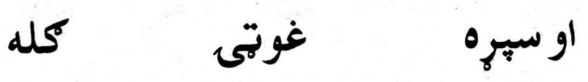

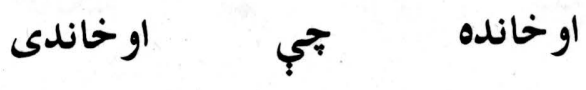
ستورى سيوبر مى كله

له

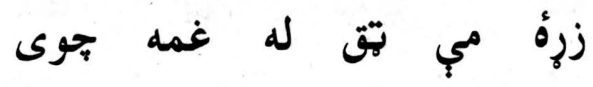

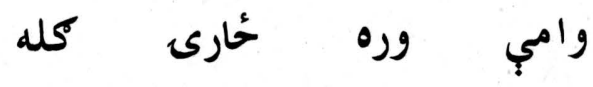

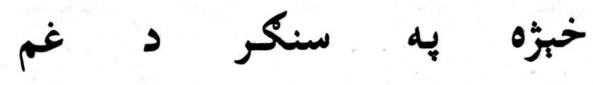

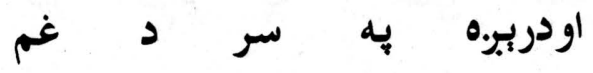

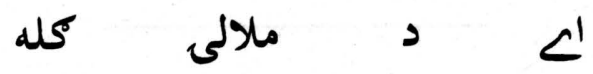




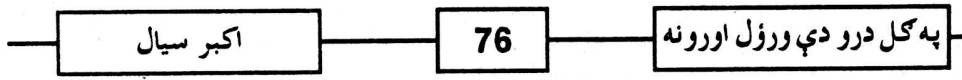

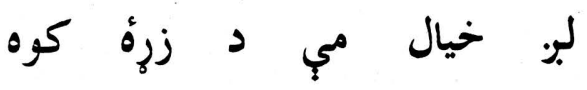

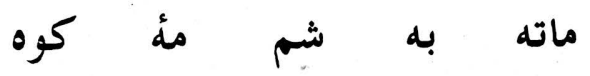

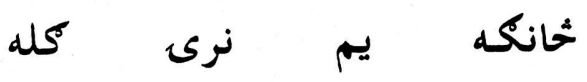

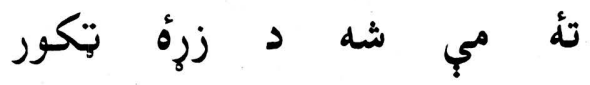

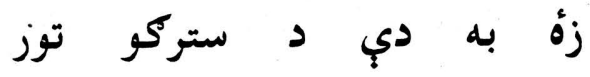

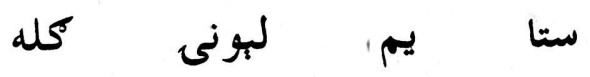

ستا

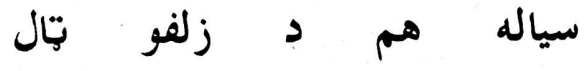

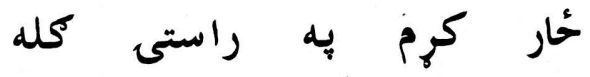



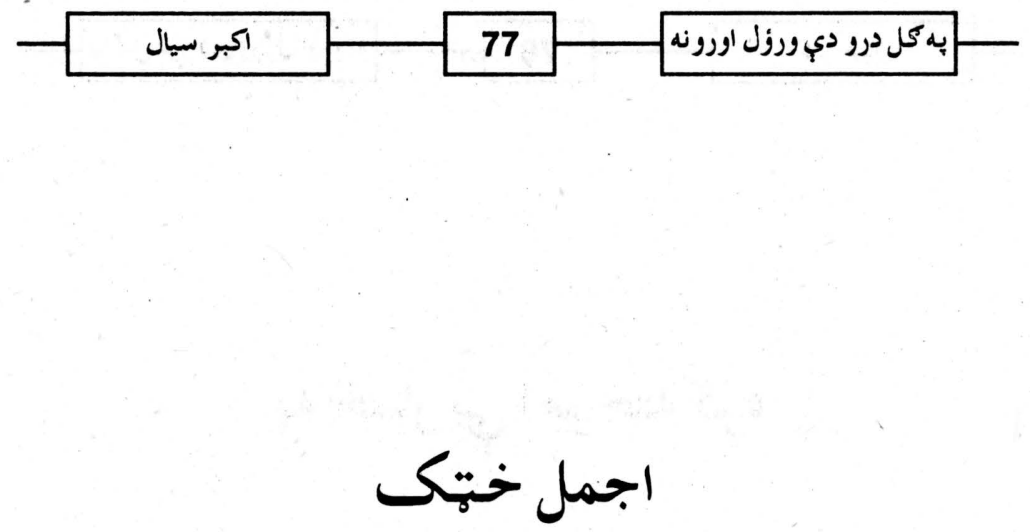

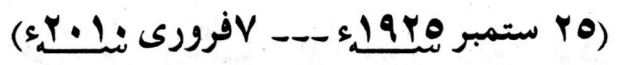

كس لاس يي بروت ده د كابل به درياب

بنغ لاس .يج ايبنع د خوشحال به مزار

به اباسين كبني يجي وربنتخي دى بِنب

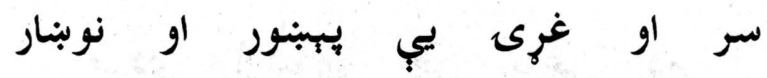

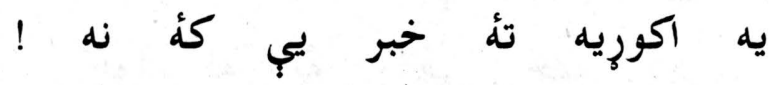
دا دي يه جا باندي كري خاوري انبار ! دا سينه ور عظيم انسان ده اجمل دا خو هبواد د لوى اففان دم اجمل دا د بِبنتون د لوى غبرت جغه ده دا د مظلوم د زرة درمان دمل اجمل 
- 78

يه خمار يب اموخته كره

اله د رنكى او نور نه ونكي

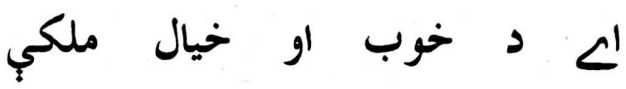

تأه خبر يبي تئ خبر بي؟

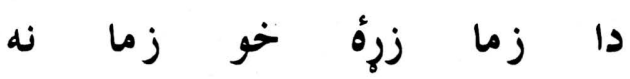

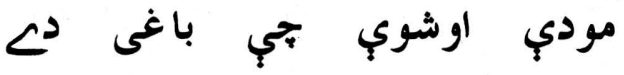

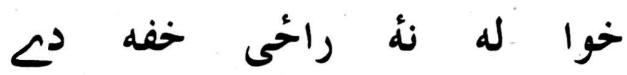

مرور

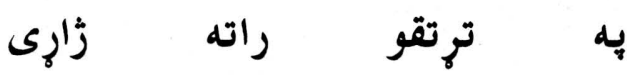

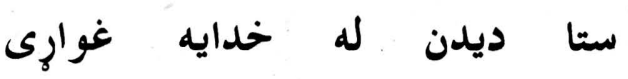

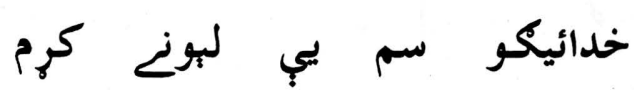

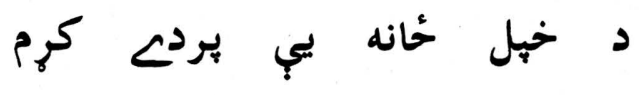

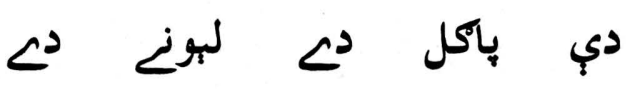


اكبر سيال

79

به ككل درو دي ورزل اورونه

زهٔ يب هم به غزونو سر كرم

د زوندون ، كلى او كوره

د دستور نه ئي بهر كرم

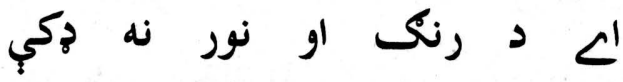

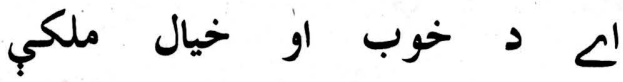

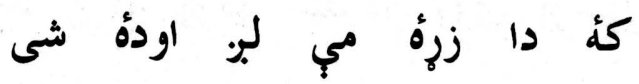

كؤ دمه شى

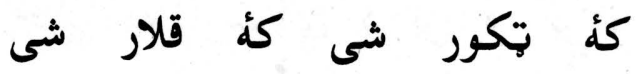

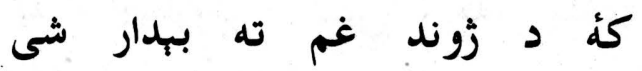

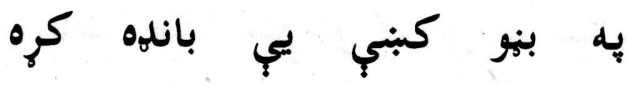

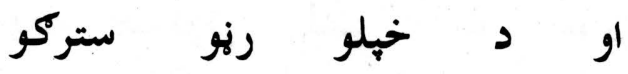

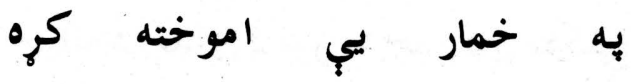




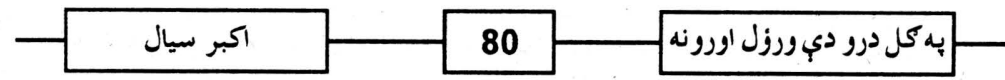

0

نور به كلونو لمبي مله بلوئ

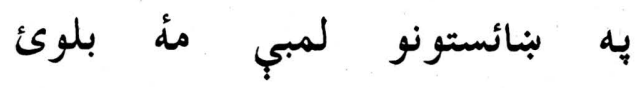
د اور د ذاته نه يبدا يى مخو زمونب. يه زرونو لمبي مئ بلوئ د اننكو اور له اوبئ وركوى

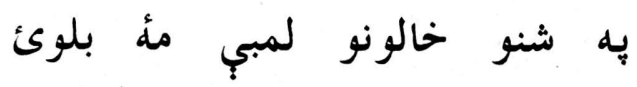
د زركو زركو ستركو روى اومنئ نورب پيه غرونو لمبي مله بلوئ جالي به اوسوزى د بن د مرغو

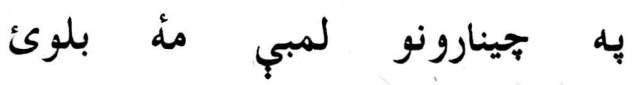
ستاسو مندر ستاسو كرجب ته سلام

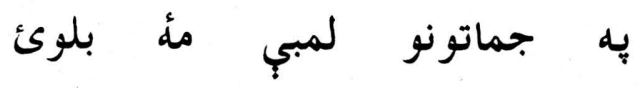
سياله د خداى د نُور نه جور دى بنكلى يه كل مخونو لمبي مئ بلوئ 


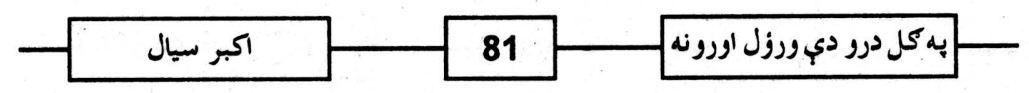

0

يروت جي وى د ببنو لاندب قانون زمونب.

رابه شى به زوند كبنب شحة بدلون زمونب

غر زمونب، رمه زمونب، او شيون زمونب.

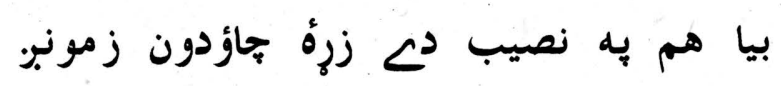

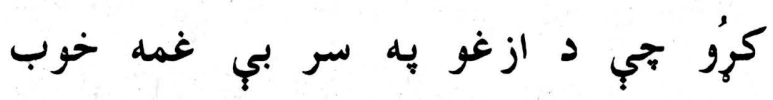

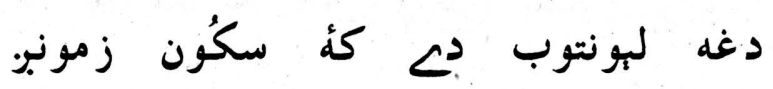

خداى خبر جي عقل تري نه جرته لار

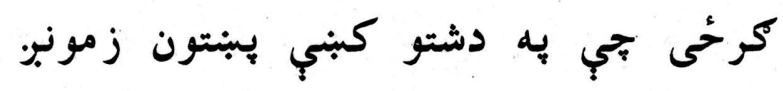

دا كربنه به ليكو يه تندى د وخت

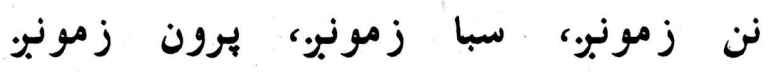




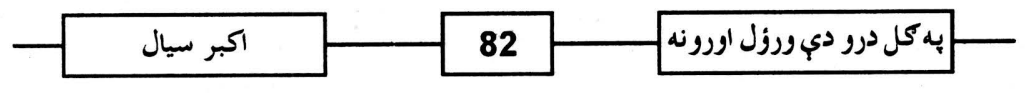

كرم به يجي به كوتو كبنب ريبنب ريبنب

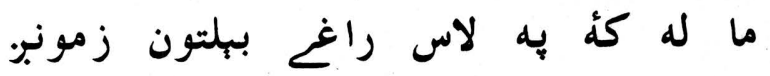

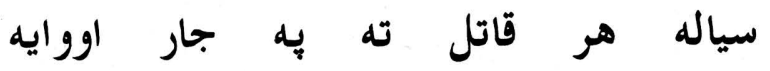
سا اخلى به وينو كبنب زُوندون زمونب. 


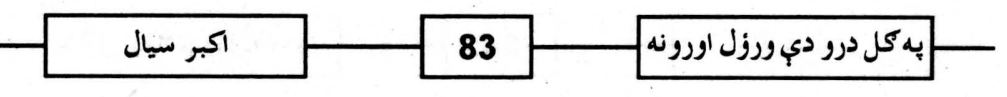

0

دا جي د يار د زلفو سبورى يه غرمو يسب حُى

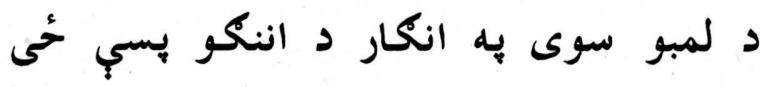

د ميني تنده د درياب به جهيو نهٔ ماتيبرى

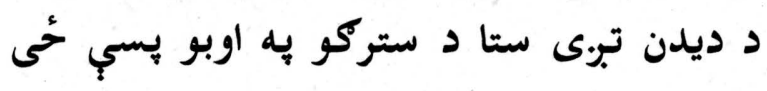

ريبنمينو زلفو ته دي وايه جب به ستركو مئين

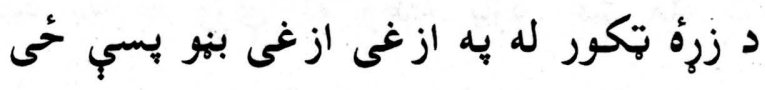

د نصيحت د رنحُورانو نه تنكى شوى خلك

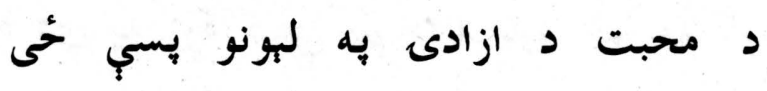
أي د رنا خاونده بل كره جراغان د كلو زرأه رانه هره شيه د بنار به تماشو بسي حُّى يه بنجارى راشه د كلى كوثخي اوشرنكوه

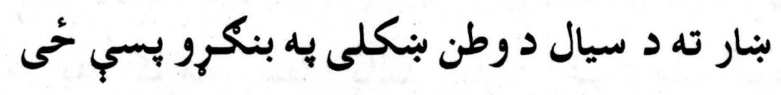




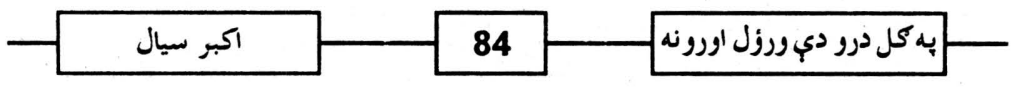

0

جي به غرمو حُو كلبدنه ياره غم مئ كوه زهٔ به وهم درته لمنه ياره غم مله كوه

د زوند غمونو ته دي ملا به تار د زلفو ترم كلهه به نه وري له وطنه ياره غم مئ كوه

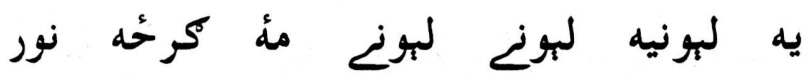

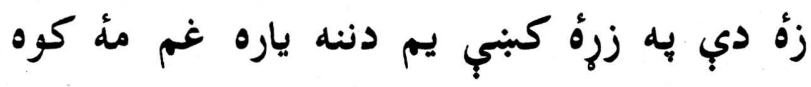

زهُ به د خهل جبين خولي دا ستا به وجو شونلهو در شخخوم به غونلهه زنه ياره غم مئ كوه

تؤ د نازونو د مو سم يه غبر. كبني يبروت او سه تل

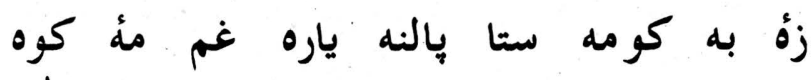




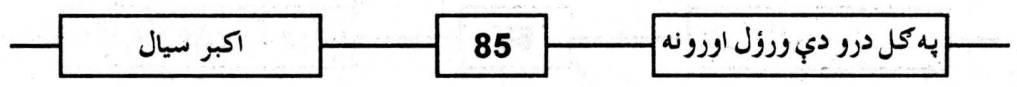

د حيكَر تاؤ به دي به شونلهو يترى نهٔ جوروى

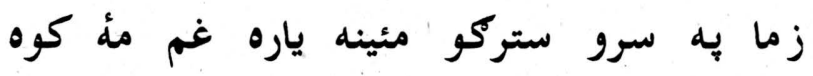

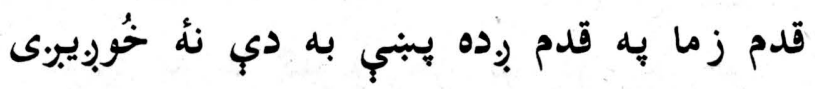

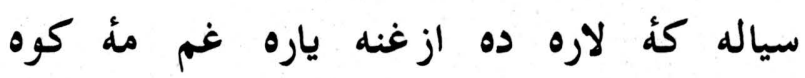




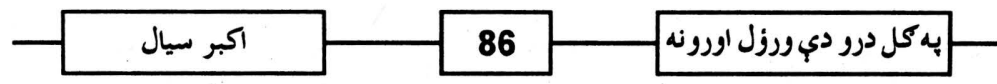

د يُبنتو نخو ا سبل

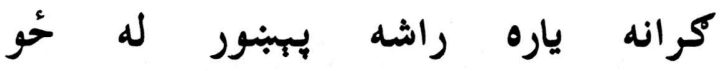
هر مابنام به صدر ته تجكر له خو لهاره

حؤ جي د نوبنار نه د مردان به لور

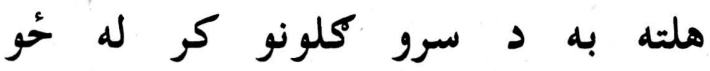

سوات مي سم به زئه را وربدلخ دئ

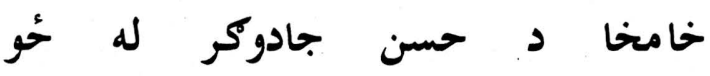

دير دي كئ جترال كئ باجور بنكلٍ مونبر به د ككلونو هر يو در له خحو

ور به شو كوستان ته د شنكلي به به لار هم به بتَكرام هم به تور غر له خو لهو 


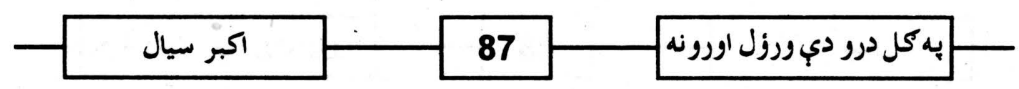

ور به هزارب ته به جركه شُو لبه

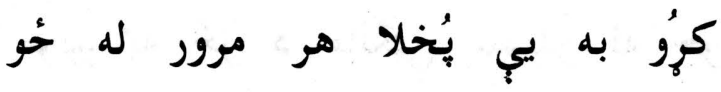

داسي به راتاؤ شُو د اتتك به خوا

نيغ به د آمو د سيند كودر له لهو لهو لهو

ستركب به خوبِي كرؤ به مزار شريف

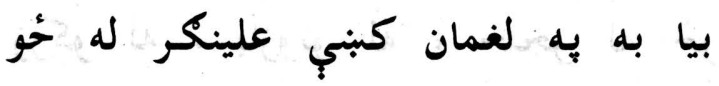

دي خوا ننكرهار اخوا لبنائسته كابل

مينخ كبنب به د غرونو ماهى ير له حُو له

كوته ده يشين او كئ زيارت اشنا

هم به قندهار ته د زئه سر له له 


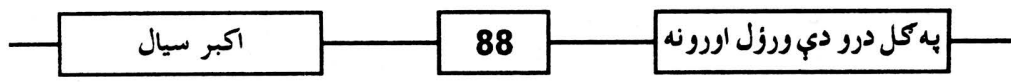

خدايه كرك مور كرك بيه خوبرو اوبو مونب. به تحو د مالكي سمندر له له

تهره به غرمه كُؤ يه مروتو كبنب

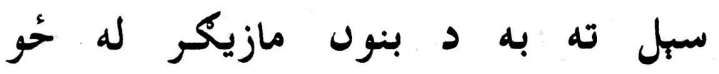

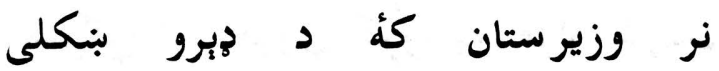
زركو له ، بازونو له ، خنجر له حو

زانكو به د لوى پاره هينار بِه تِل تّل او اوركزو ته يو نظر له له

راشه د وبر مو پِه تَال به اوزانكو كور ته به د حسن هشنغر له له لهو 


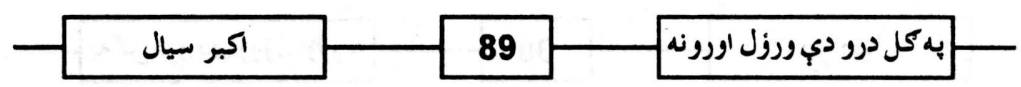

تا له به اوربل كرى ما له زئه راخور

زوب ته به د تبزي هوا شر له هُ له

اوس مب زرأه د كوتي نه تينك اونيسه

تا وي مبكدي ته به خبر له له له له

شيه به به مابن كبنب به خوند تبره كُور

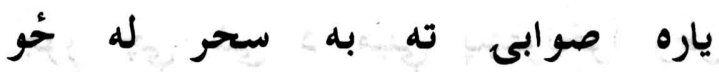

جاوي جب وجشيان دى ببنتانه ياران

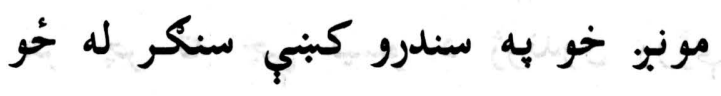

كج به كرو بكتيا د بكتيكا غرونه

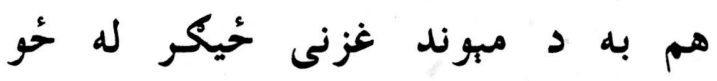




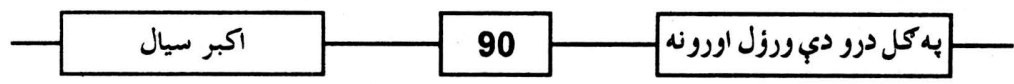

دشتي د مهمندو به هم اوكورو هلته كبنب لامبلو له به نمر له له

جور جي شى د ميني بِبنتونخوا وطن

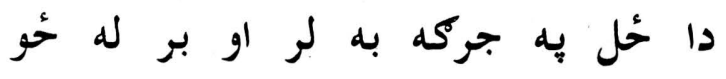

هر جر ته جي نيسو د زوندون روزي سياله ملاكنله ته به اختر له له له 


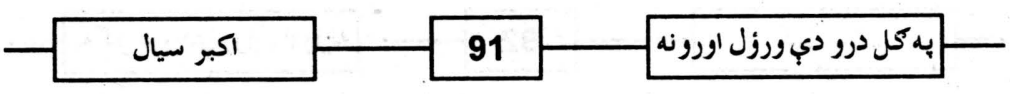

كمال محسود

(21-3-1951---6-1-2010)

د ل محسود فنكار

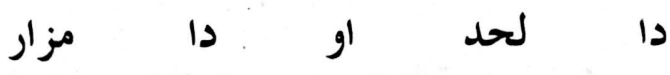

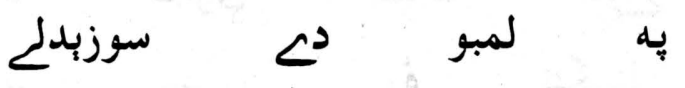

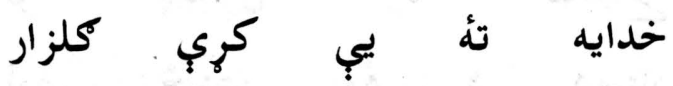

رنكين رنكين غزل

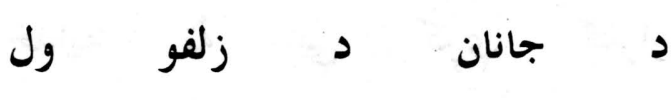

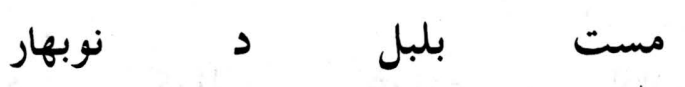

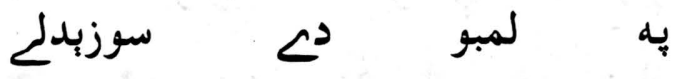

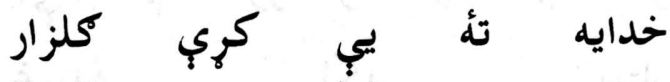


يه

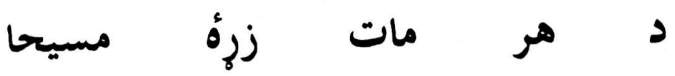

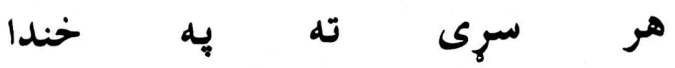

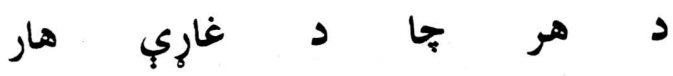
به

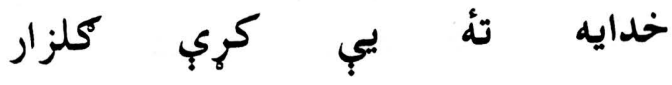

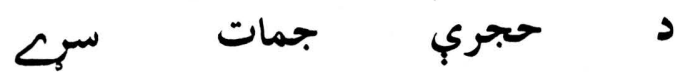

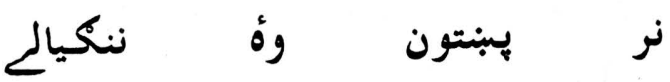

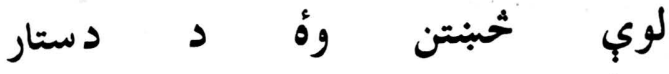

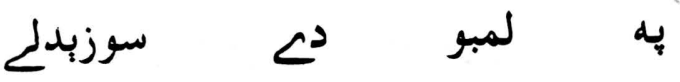

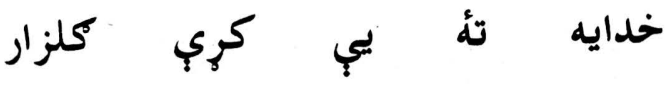

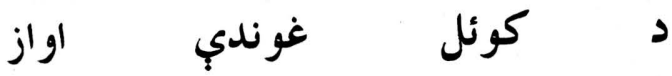
جب هم سوز ؤه او هم ساز

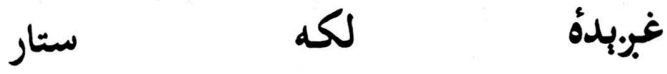




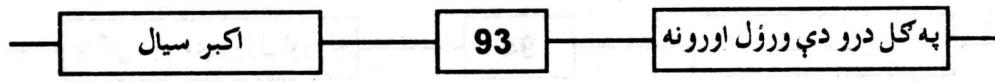

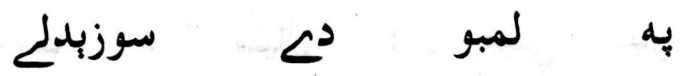

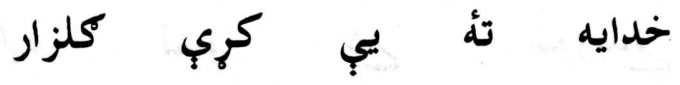

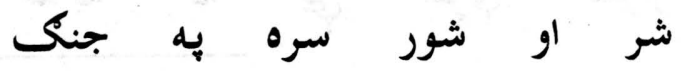
تول د ميني رنك كبنب رنك

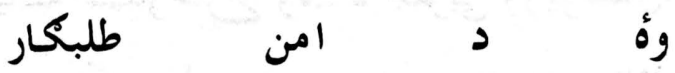
به

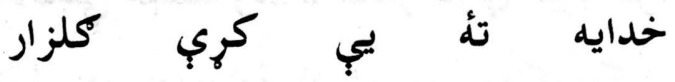

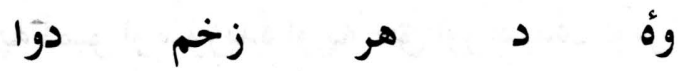

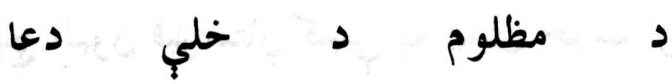

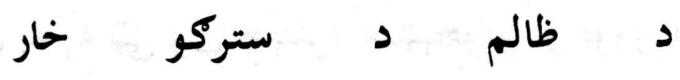

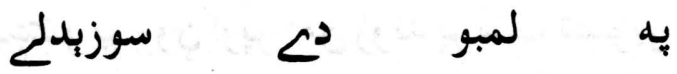

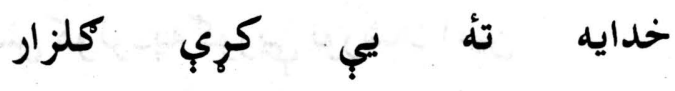




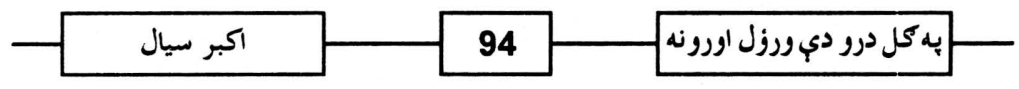

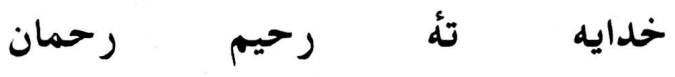

مهربان

بخبنو نكم

هم

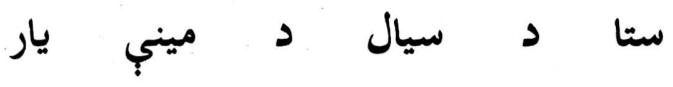

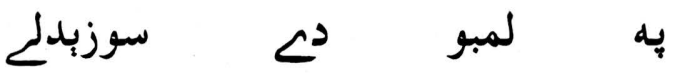

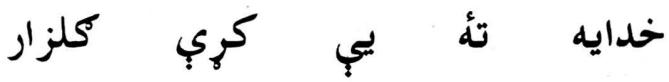

يادكبرنه:- اروابناد كمال محسود د يبنتو زببي يوعالمى

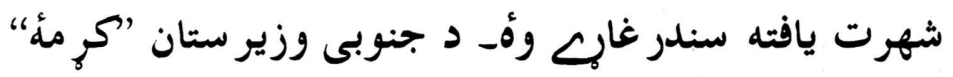
كلى او سبدونكح وهُ د وزير ستان د ناسازوحالاتوله كبله اسلام ابادكبني مبشته وهُه د سندر غارى سره سره يه يهبنتو او يبنتونولى ذُبر مئين وؤه د شيب يب يه كور كبنب جا اور اولكوهُ به لمبو او سوزبده او يه حق اور سبدهُ اوس د اسلام اباد به ابِج البون قبر ستان كبني يه ابدى خوب اودهٔ دهـ نو مورى به يه تيى وى جهنلز، ستبجونو او نورو محفلونو كبني د يبنتنو يو روي اويُر امن زُوند بر ست تصوير او تصور دنياته يبش كولو يه كوريجي نورشهـ امين 


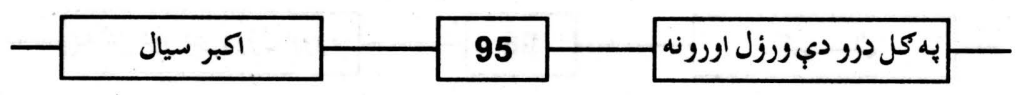

\section{0}

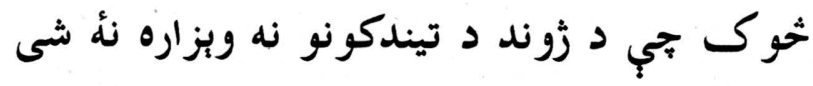

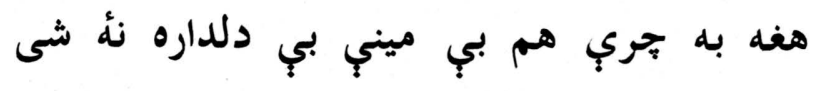

زما د بنكلو دي خداى مل شى ترهغي نبنتى وى

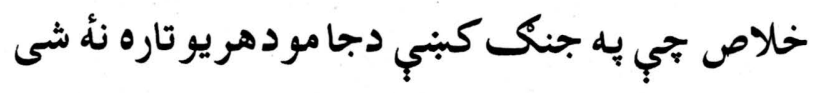

د ستركو غشى به وريرى تر هغي به دنيا جي د الفت د قاتلانو نه اوزكاره نه شى نه دئ لبونغ نه يم جي مي زيرة خحانله اوبئة اوبئة كرو

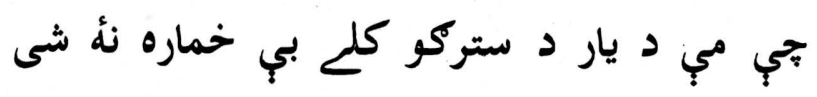




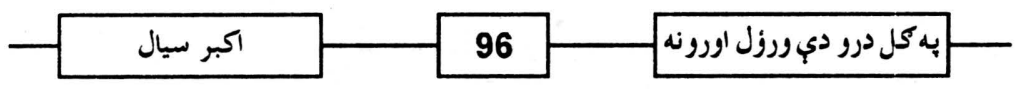

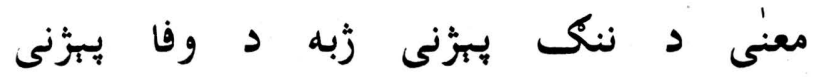
دا غرشنى جينى دي جرته هم بي ياره نهُ شى لئى

يه د الفت د د بسرلى بارانه راشه كنه

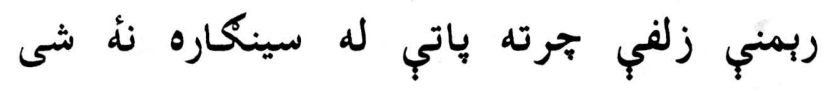
سيالذ به دوارو لاسو اونيسه د زرئ دنياكى

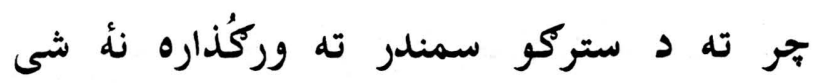




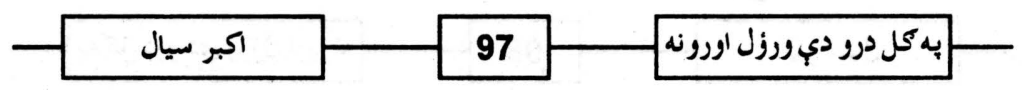

0

خور شو يسرل د كمل غوتى بـ سر

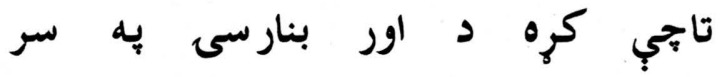

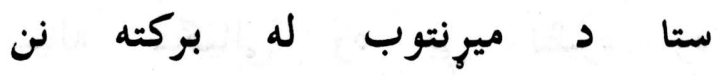

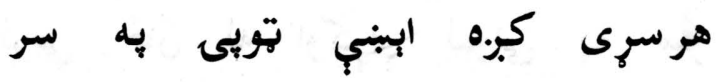

سبين مخ جي يجي اوليده به وينو سُور خاورب حُان له اونوستي سيوبْ مى به سر سيه يه قاتله دا خو وه د روند بنكلا

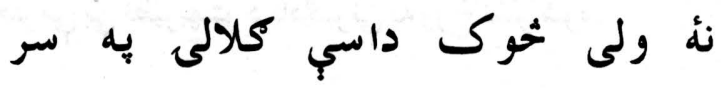




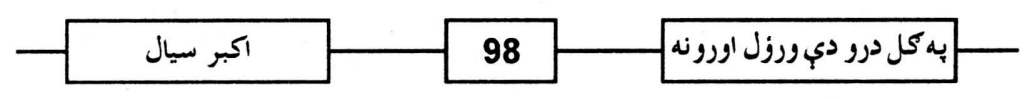

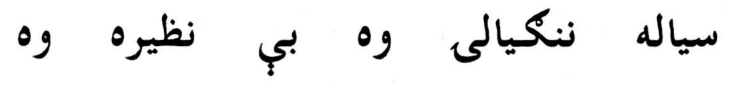

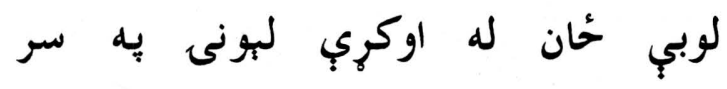

يادكبر نه :ــ داغزل نما مرثيه د بنا غلى فاروق مو مند بِه خوبنه اوليكلب شوهـ د

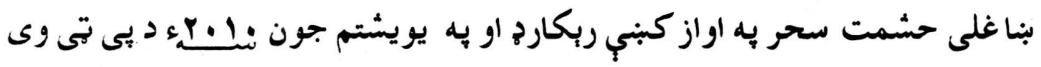

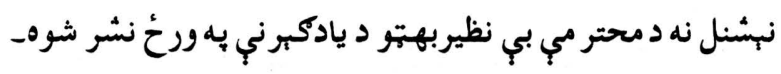




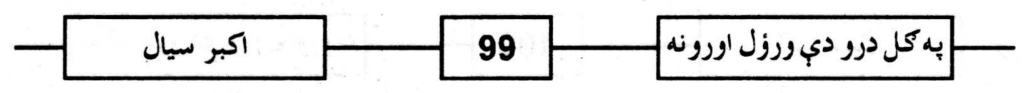

\section{0}

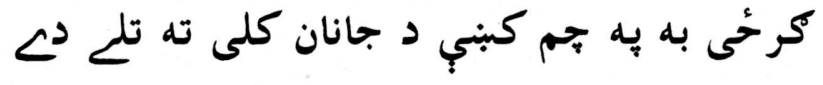

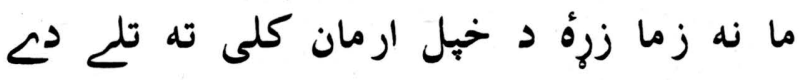

زركي زركب ستركي يب به زرهُ راوربدلي وي

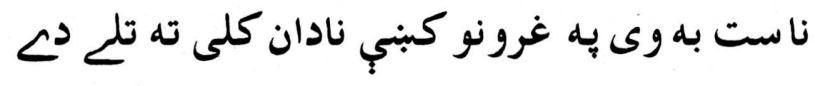

تورب توري زلفي يب د غارب نه تاؤ كهي وب

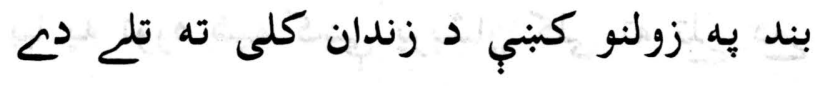

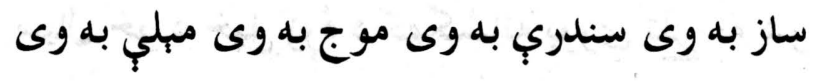
ناست به تري حابيره وى ياران كلى ته تلح ديد

وينخى به د دبنار د كلبدنو د نظر خيرى

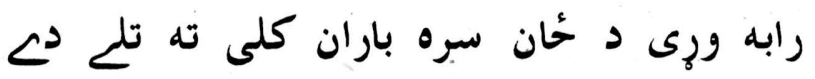




- 100

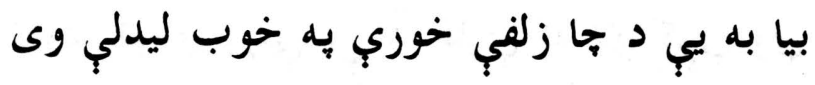

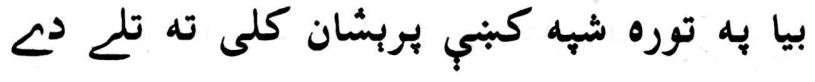

سيال خو د خيل زرةه د كهكشانه يورب تلـ نه شو

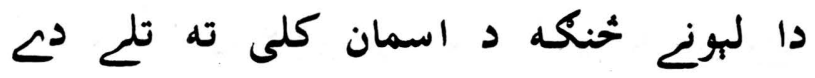


به بهل درو دي ورؤل اورونه

0

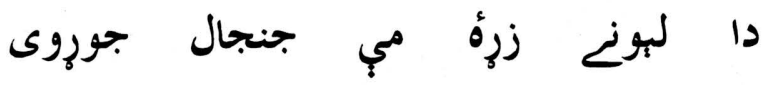

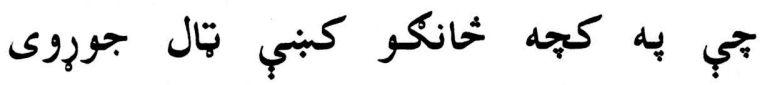

يو خوا مب تبن د ديكر د د وينو

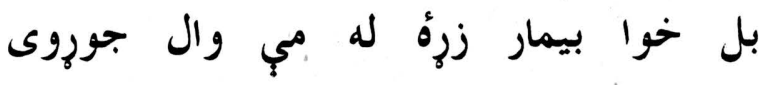

كركه د زرة د د لال نه كانغ كرى جوري

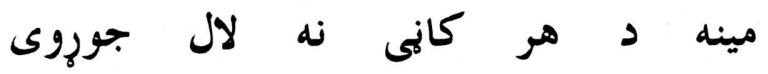

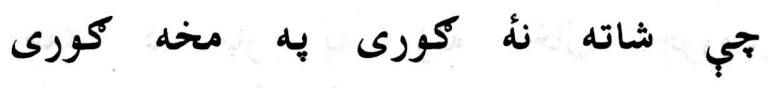

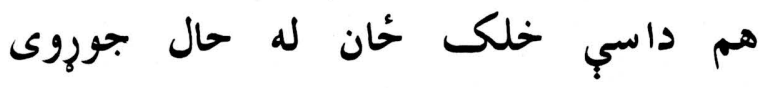

زلفو له تحنله وركره رامخ كره ياره

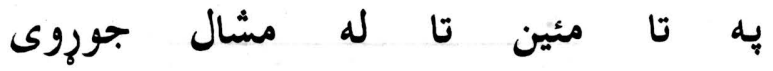




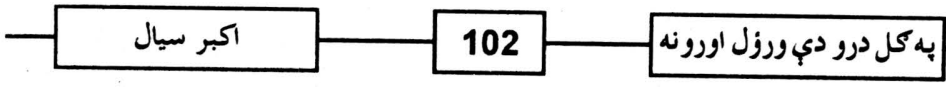

نيت د كلجين او د بورا بنئه نهُ دان

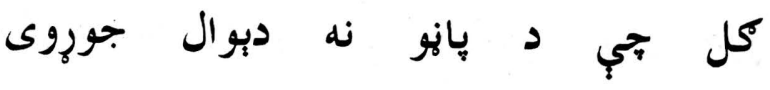

تلٔ خفه نهٔ شب هغه نئ دي اوزكار

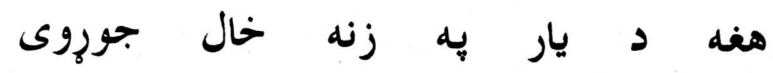

سيال دي د تولب دنيا سيال :جوروى

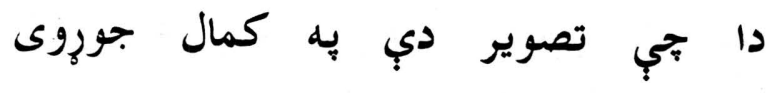




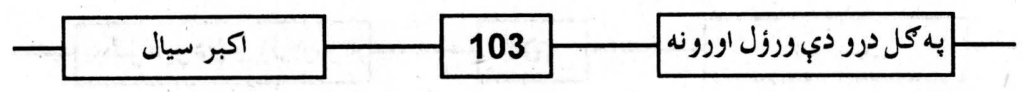

0

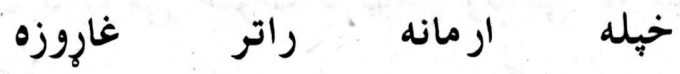

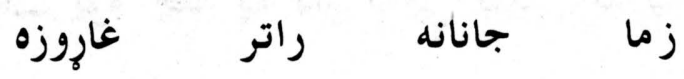

نور به لا ثخو مره يه ما سر كرحوي

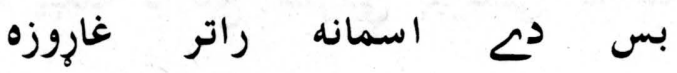

يه ما الزام د رقيب مله لكوه

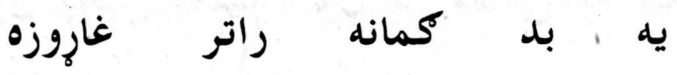

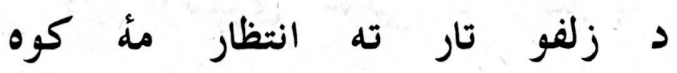

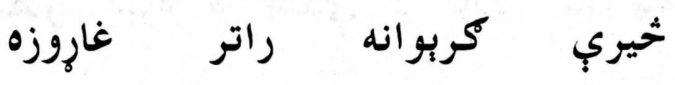

نوره دي سرو ستركو ته نهُ شم كتي

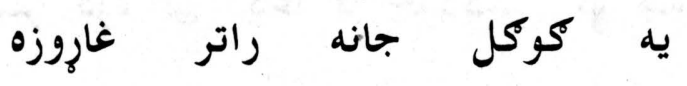

سياله زما دزني هال شه اشنا

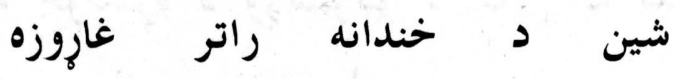




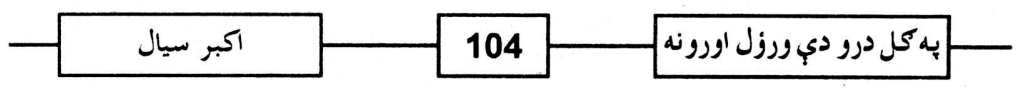

0

مركى د قومى غبرت د تولي زندكى نه بنئُ وى د ننك يوه هغه پيه دار د بي ننكى نه بنه وي

جي شى به ستركو كبنب مسكى مخ ته يلو اونيسى

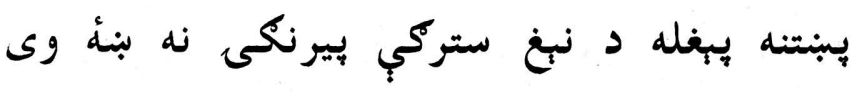
أه د جنت او د دوزخ به قبد كبنب بروت واعظه

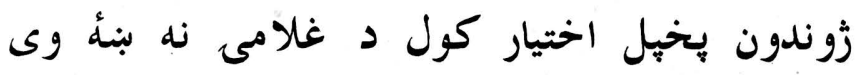

سيرل دي اوسيرى غوتى د ارتقا پيه كوتو

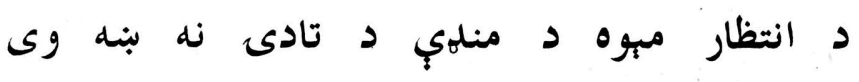
د زوند او مرك د ازيت به بريد ولاره كله د صبر دوه ليب دعا د خودكشى نه بنه وى بي غمه خوب، ستركي مَري، د صبر وجهه دوديى

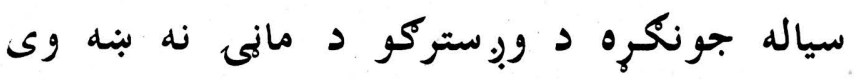




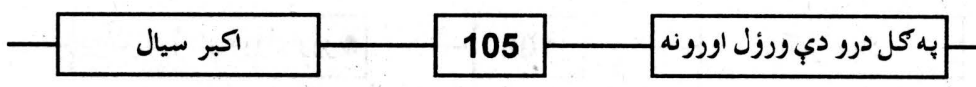

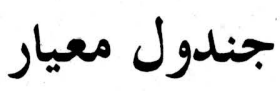

زما د بِلار نيكة وطنه به تا شحهُ شوى دى

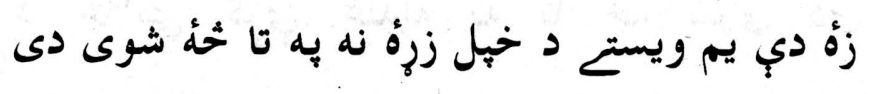

تهٔ دغازى(1) عمراخان د ننك مورجه شخنكه يج

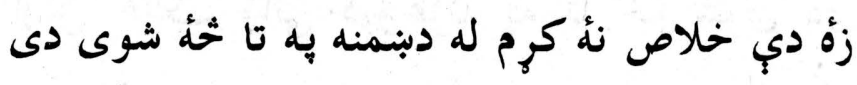

تا د غازى عمراخان به بهو لوبي اوكري

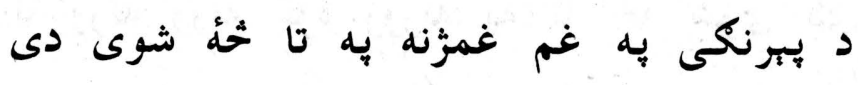

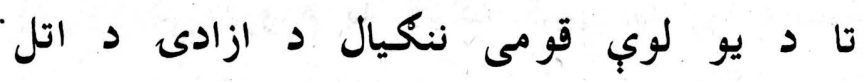

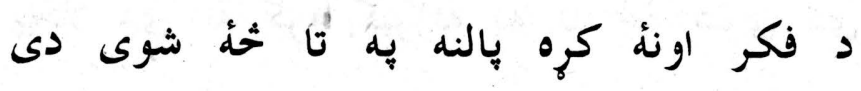

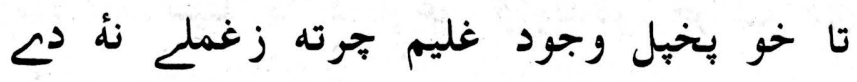

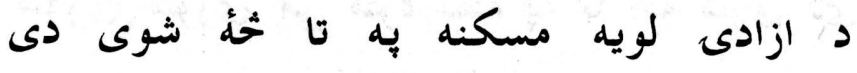




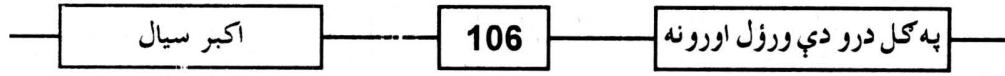

زما پِلرونو ستا پِه سر د هِبرنكى بِه خلاف

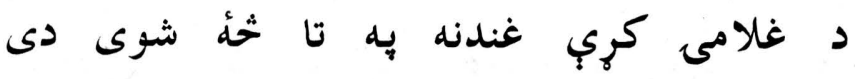

ما خو معياره ستا به تول وجود خانى كري ده اوس خلك وائى دروغزّنه بِه تا شُهُ شوى دى لى

ستا غاصبانو در به در كرل ستا د مخخ مئينان

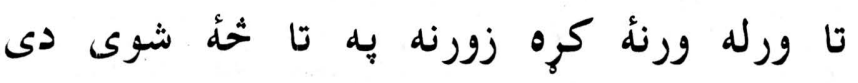

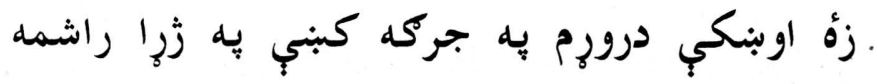

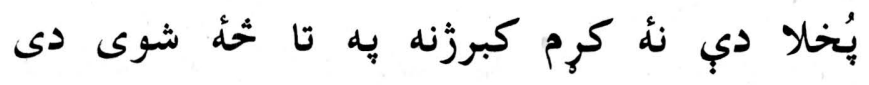

ستا پِه سينه دا د ازغو كروندكر خحوك دى

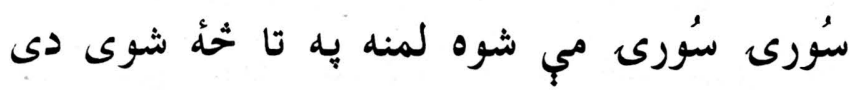




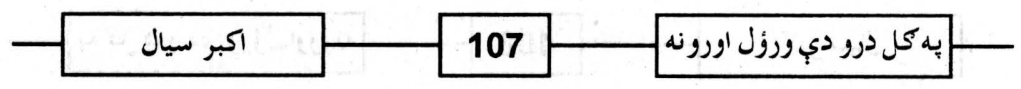

ستا پِه دي دومره بنكته بورته ارته لويه سينه زما نهٔ قبر شته نه ونه به تا خحهُ شوى دى

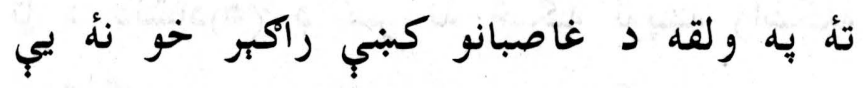

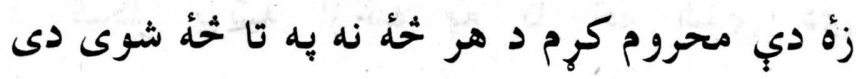

ما خو تول عمر تراني ستا ده عظمت وبلب دى

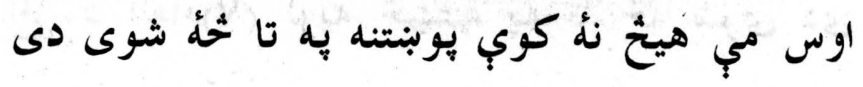

ستا هر يو كانى دى اغوستب د رنكونو جامب

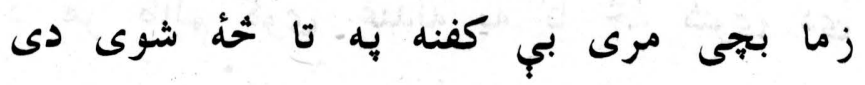

د يو شاعر به ملكيت باندي قابض كافران

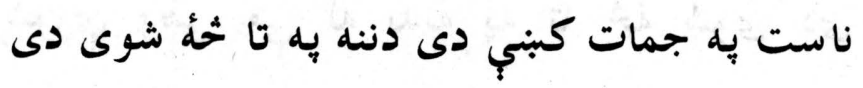




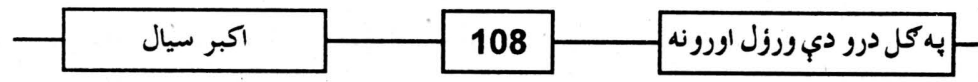

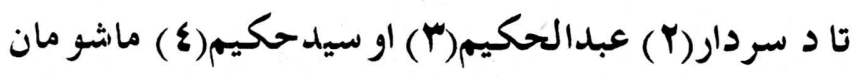

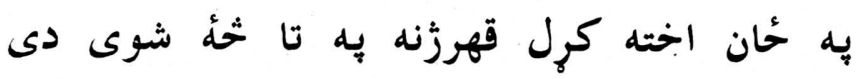

تا د دلشاد(ه) د سر نه شخنكه لويتجه رابنكله

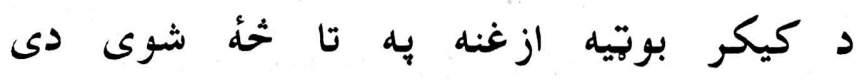

د ننكيالى امان(ا) د ستركو نه لب. اوشرمبره

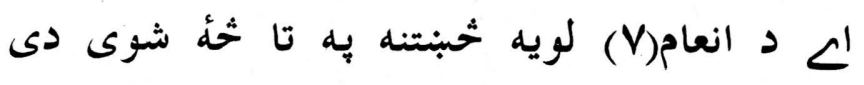

كوثر(N) يه يو لاس كبني قلم بل كبنب تويك نيولـ

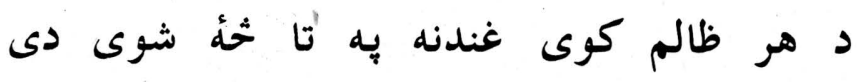

يو خوا هبنتون شهُ داره مار بل خوا اخون ليوه شهٔ

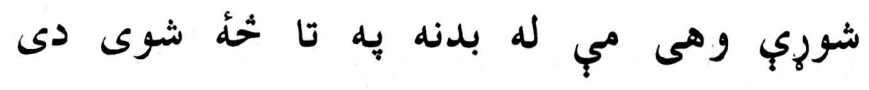




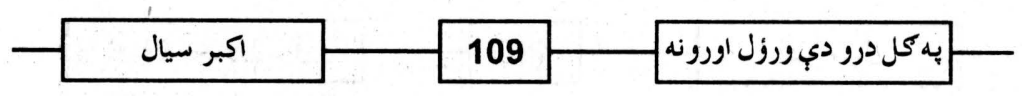

تؤ تي سيرلغ سبرلح كلاب كلاب غانتول غانتول شه

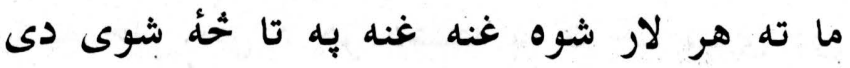

اوشوب مودي، د غربوه ذِك يمه، سلكو نيولِ

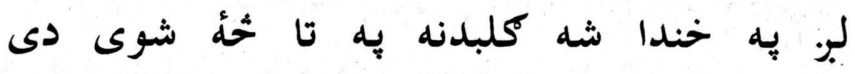

على حبدر كوثر قلم ده هم تويك راغست

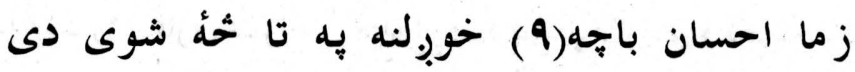

شكر به دي جي زما ستركي جا ته تيتهي نهٔ دى

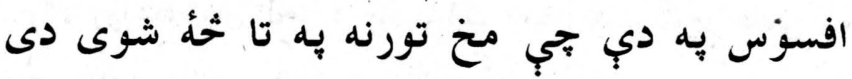

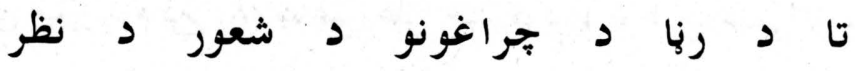

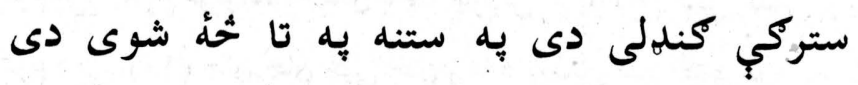

نهٔ توبِك مار، نهُ دهشت كَرد، نهُ وطن خرخخ يمه

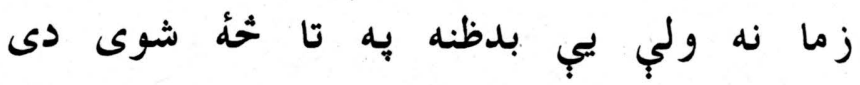




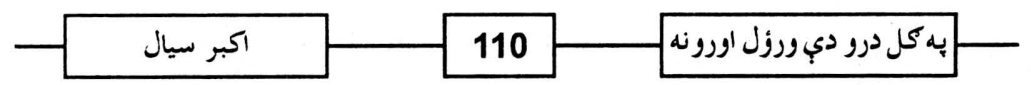

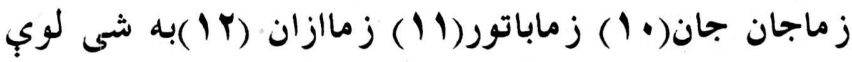

وا به خلى حق د هر دبنمنه يه تا خُله شوى دى

سياله راحُه، نر شه، تكزه شه، به سنكى اودربره د خهيل اولس يه درد دردمنه پيه تا خهُ شوى دى

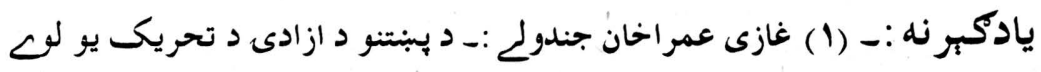

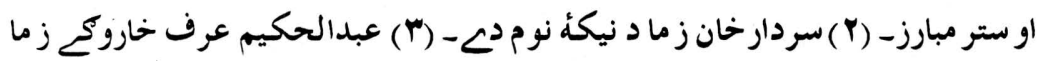

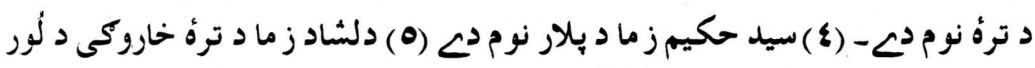

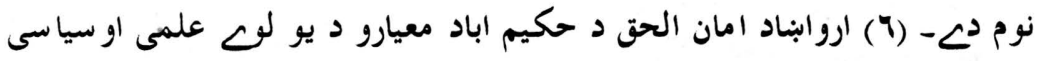

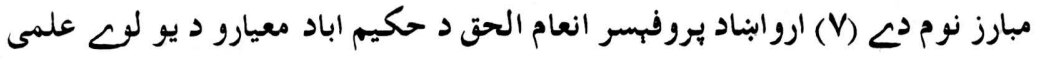

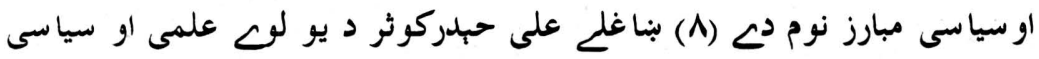

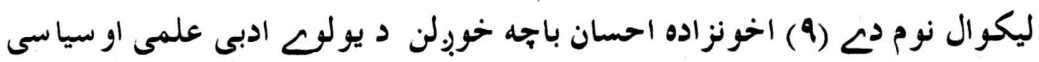

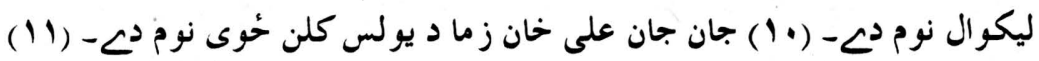

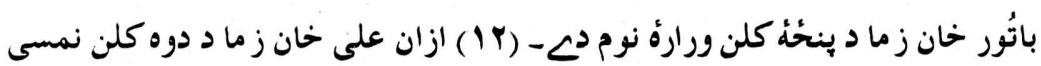
نوم دنه - (اكبر سبال) 


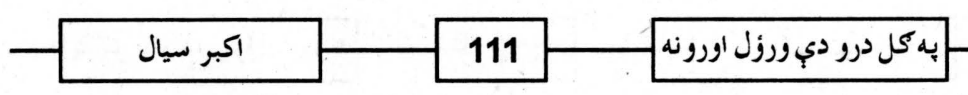

0

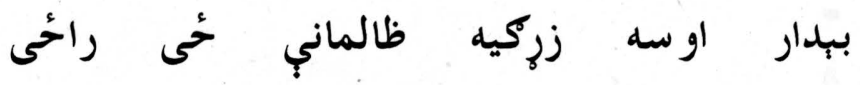

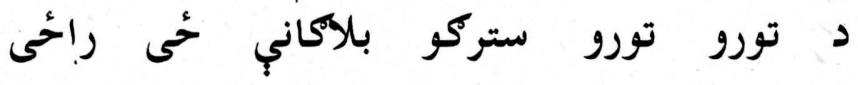

مخونه به يبي يتّ وى د حيا پيه لويتوكبنب

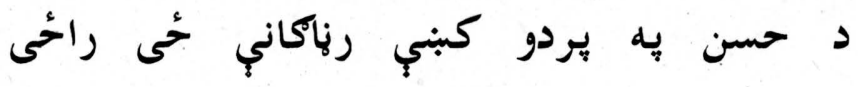

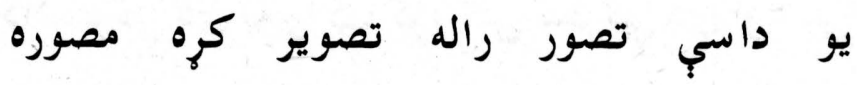
د شونلهو نه تجي شونلهو ته ساكاني حُى راحُى

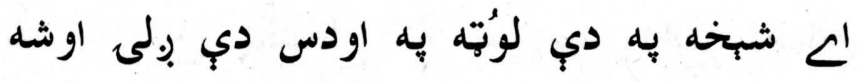

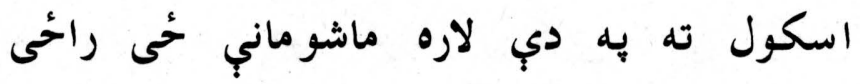

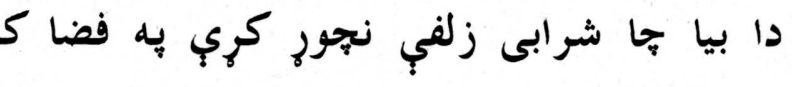

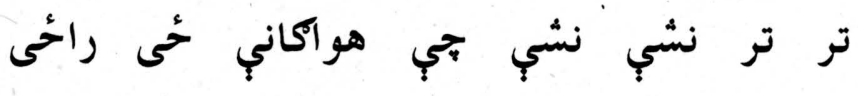




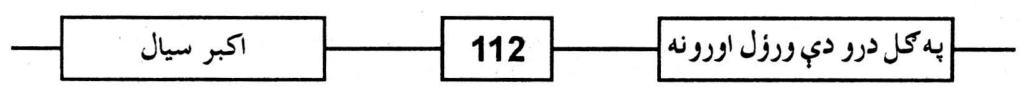

دا ستركي دي يه واك كره كنى ستركي دب اوباسى

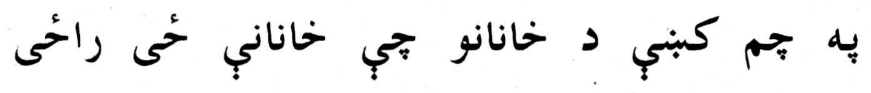
نهٔ اور ده لكبدل نهُ سبلاب راغلم سياله

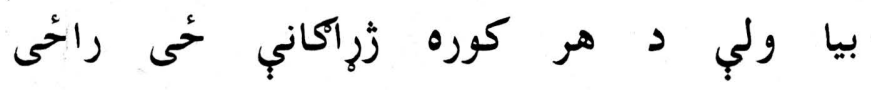




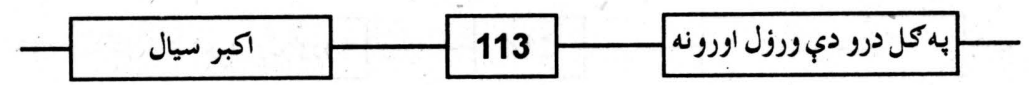

0

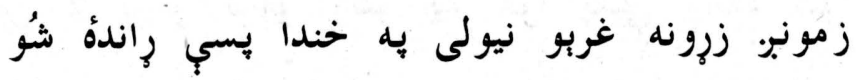

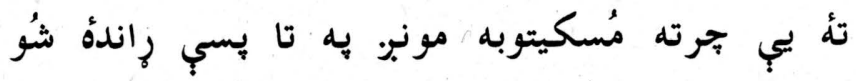

به دي بن كبني جرته قات اور اوركى خو داسي نهُ وو

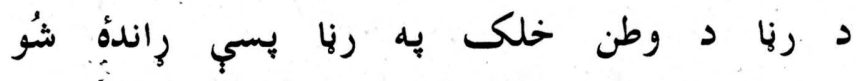

بس د يو نظر ديدن له به دي لارو دي كوخو كبنب

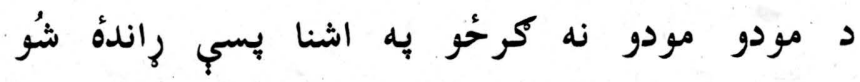

ديه يوترخ كبني مب كوكل ديه به بل ترخ كبني مي لبمة ده

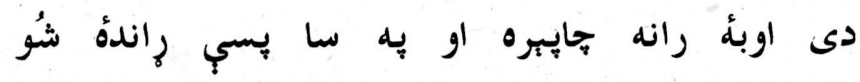

ستا د تورو تورو زلفو د سبين مخ مهربانى ده

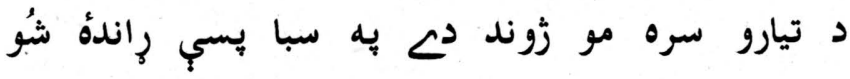




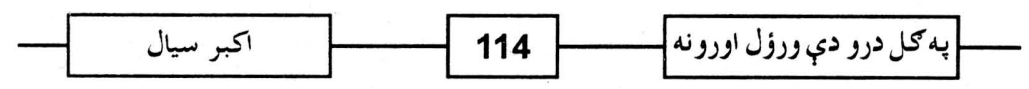

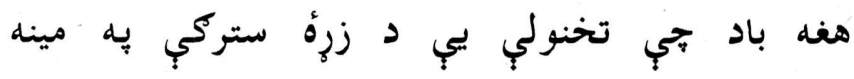

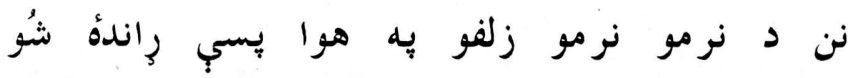

لويتني ترب هوا يوري او جامب تري سبلابونو

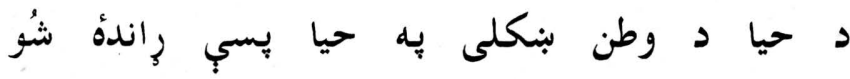

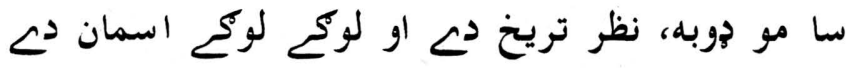

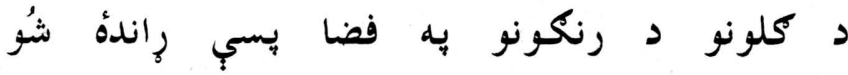

تاسو كوم خوا كلدي يوري د سهرلو كروندكرو.

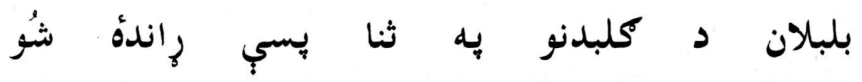
سياله نور ظلم به حخٔ وى د سهرلى انصاف ته كوره

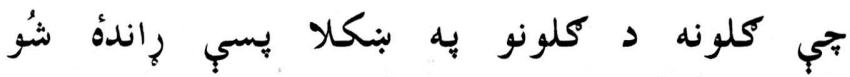




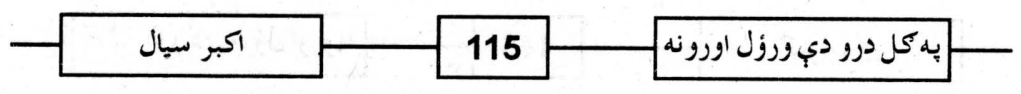

0

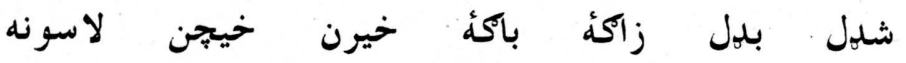

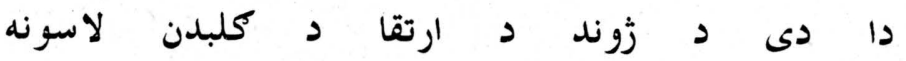

بد رنكـه بنـه دى خو د جا پيه وينو رنك نبهُ نهٔ دى

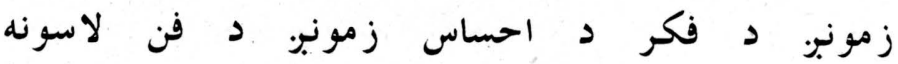

جرته به راشى يه كار دومره هم بج قدره نهُ دى

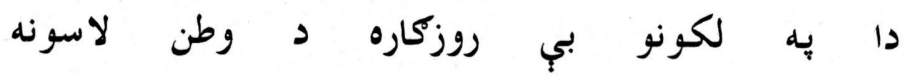

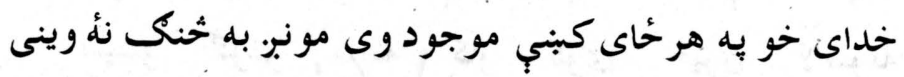
خبرات ته مله يورته كوئ يه ماسخوتن لاسونه

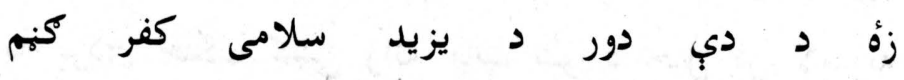

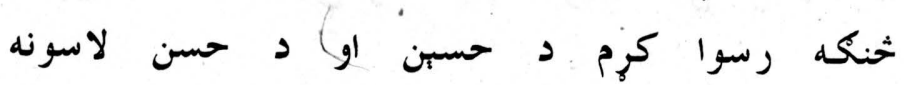

خوك به يب رنك كرى د زوندون د تمدن پيه شعور

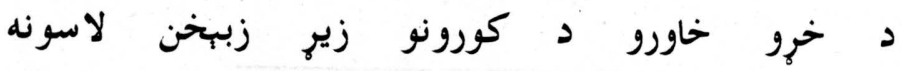




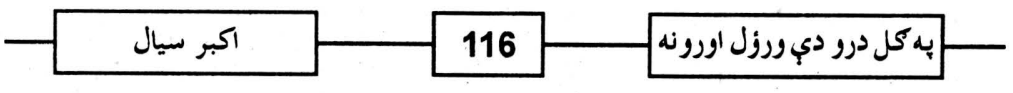

لاري كل كل حُوانى يي دل كري د حالاتو جبر

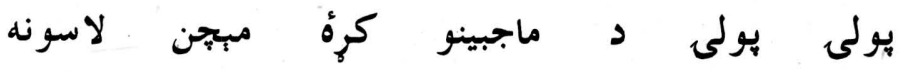

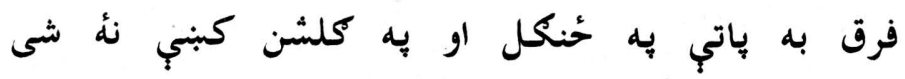

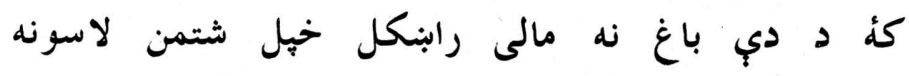

دا خب صفا صفا شخربي . ثربب منكولب لنبكارى

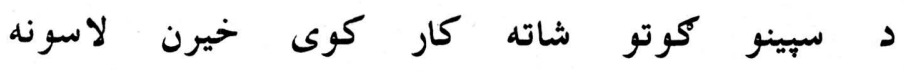

قلم مي شل تويك مي زنك كتاب وبنو وخورئ

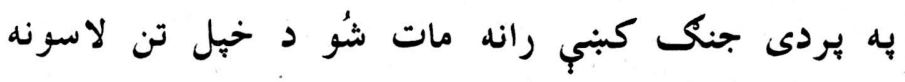

سياله خوبونه مو د ستركو نه لوت شوى دى تول

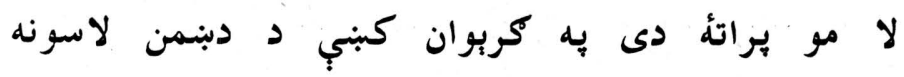




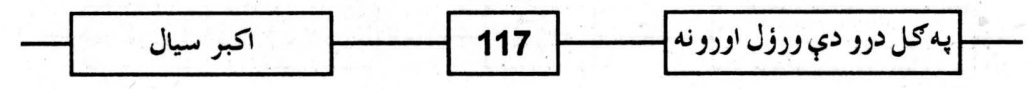

0

خلكو راباشئ ظالمان د لاسو بِبنو اوترئ

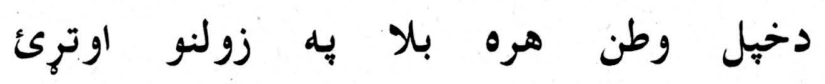

بخخيل همت د هر قيامت د هر أفت نه اوحُى

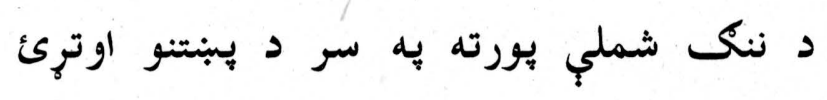

جي لبر احساس بكبنب يبدا شى د دوزخ د لمبو

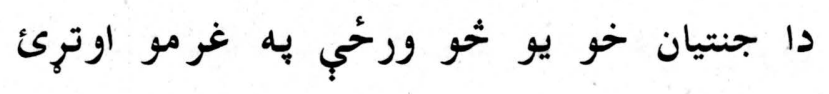

دا خو بازار دا خو كوخحه ده دا دبح بنار د حسن د خهلو ستركو هر يو خوب به تماشو اوترئ

د كلو خحانكي بند يه بند به زولنو مئ ترئ

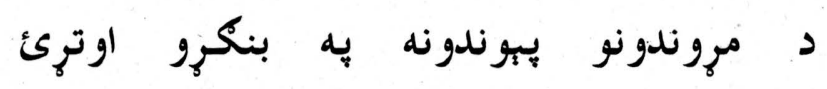


به بكل درو دي ورزل اورونه

بله يوه خطره هم نشته كملستان ته زمونبر خو دا تبرغ تبرغ لاسونه د ازغو اوترئ

دين د مُلا، دنيا د خان شوه، باتي زهُ او كملاب

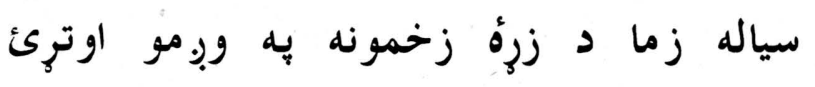




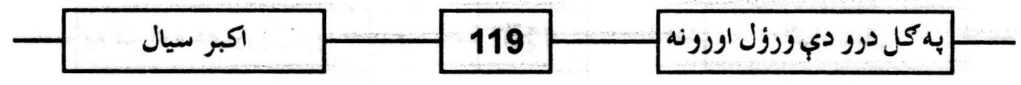

\section{0}

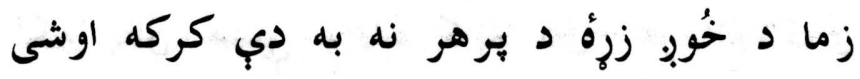

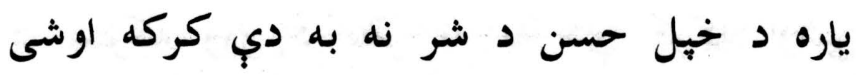

به هر يو تار كبني يب بيهلى د ارمان لاشونه

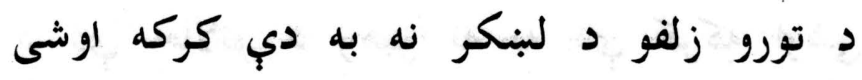

ازغ د كل به سينه مات كل د ازغى به سينه

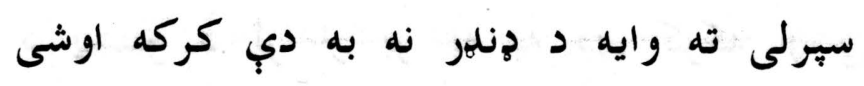

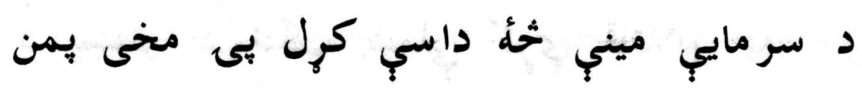
د خيل دلدار د خبل دلبر نه به دي كركه اوشى دئ دئ

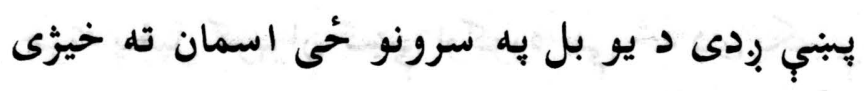

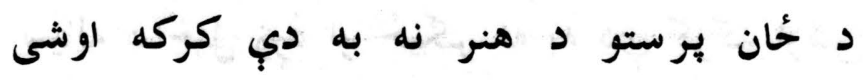




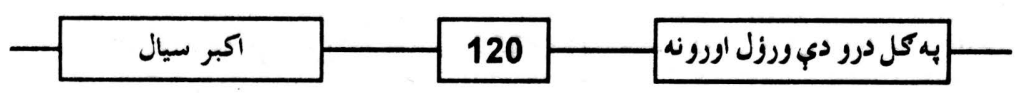

لكه بتان هسي راندة كانئه دى غبر نهُ كوى د ستركه ورو د نظر نه به دي كركه اوشى دئه

جي د كاروان ملككى مم كورى يو بل ته به شك

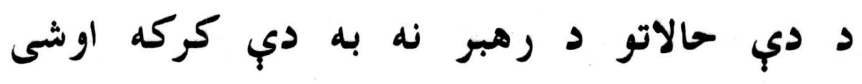

هره حجره هر يو جمات د دلالانو نه دي

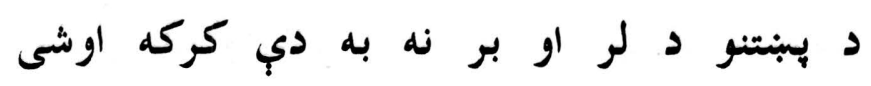

د هبنتنو د ننك شملي كري قاتلانو به سر

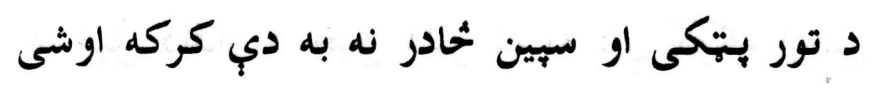

جرته بخيل ككربوان كبني اوكوره حي ثحئ دى بكبنب

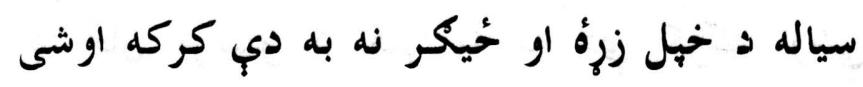




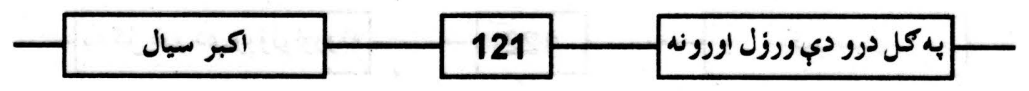

0

سم جي راته نهُ كوري نو زيرة مي ماتوي كورَي بيا به مي هر وخت به زيارتونو كرخوي كورَي لهري

هيري به كفن كرم د لحد تمبي به ماتي كرم

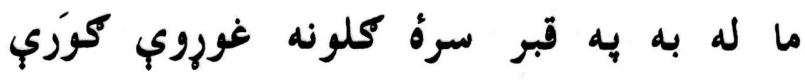

ما به د كلونو د رنكونو به تول نهُ تلغ ما به لكه ستركي به بنو بنائسته كوي كورَي لهوب

مه به شم د غمه كئ د خهل زرئ نه دي اوويستم

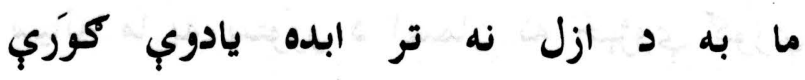

زٔز لكه غوتى به د جامو بندونه اوشلوم

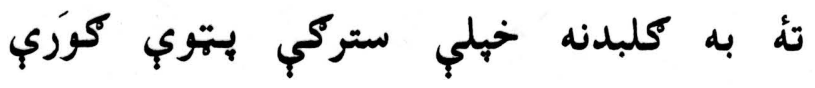




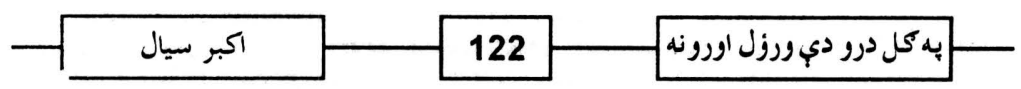

خدائيكو مودي اوشوي كئ مي ستركه بـته كري وى نن به مي د زلفو يه هر تار كبنب حُنكوب كورَّي

ستا به محبت كبني مي اوس بـنب به زمكه نئه لكى سياله ما به ستورو د اسمان ته خبزوب كوَرَب 


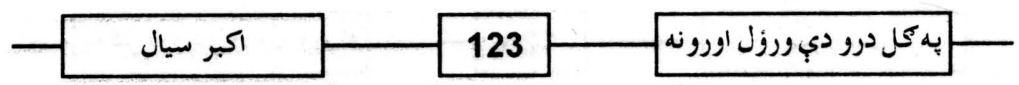

\section{0}

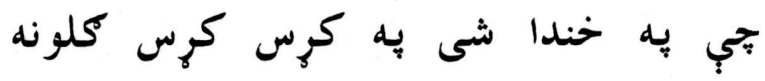

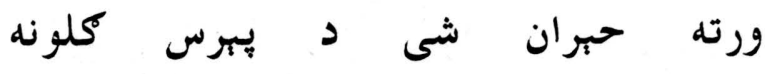

غنجي غنجي شى سري منكولب د يار جرته راتول بي شى يو لس كلونه

سيوبٍ مى ته وايه مَخ ته مهٔ نيسه لاس

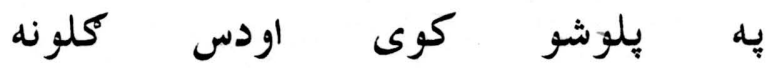

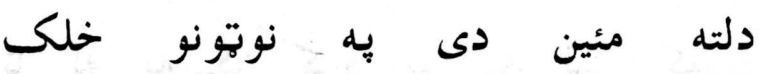

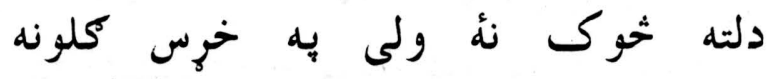

دا درته جا وب جب غريب يمه زه وطن مب باغ ده او اولس كلونه 


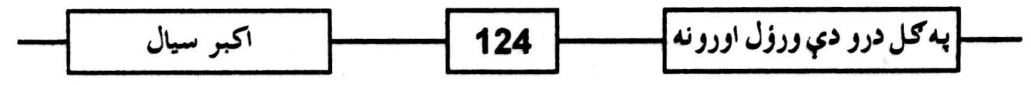

نهٔ دي تري هار نهُ دب كجري جوري كري

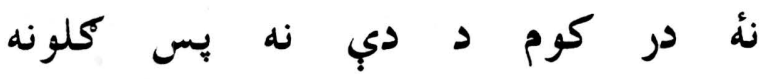

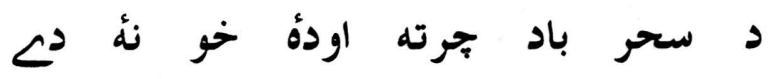

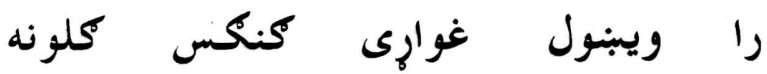
ما له له له له د ديق لاس راكره تا له به در كرم يو پِه لس كلونه

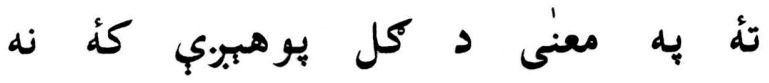

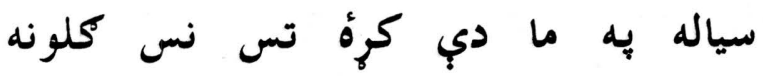




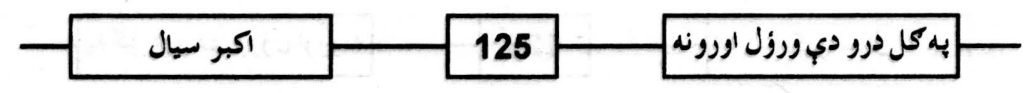

0

به سترى جنك كبني دي خيل لور او خيل ستّك مات كرو

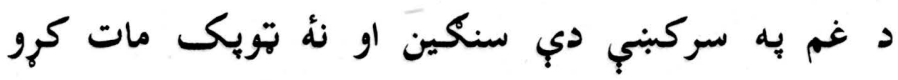

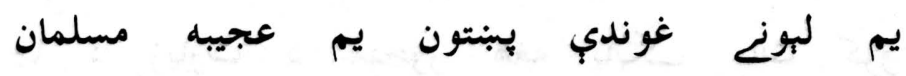
خان له مي سر مدام د خبل لاس به كوتك مات كرون بهري

زهٔ د زوندون به ترقى كبني هيخ كردار نهُ لرم

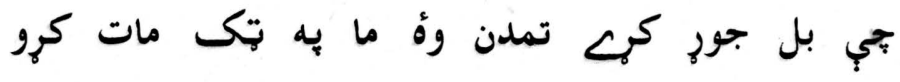

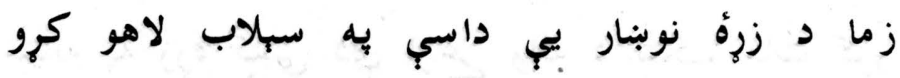

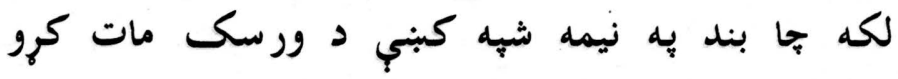

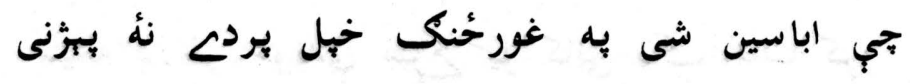

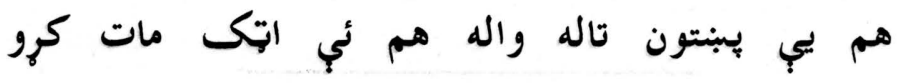




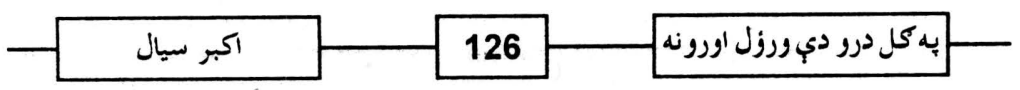

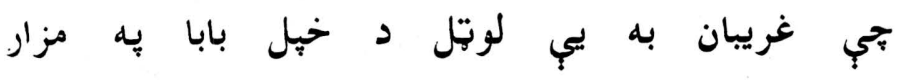

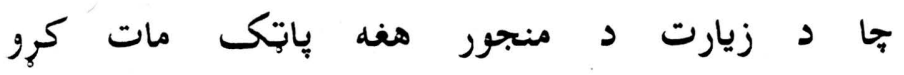

ما درته نهٔ وي جي لبوان دى اوده كبربي به نها

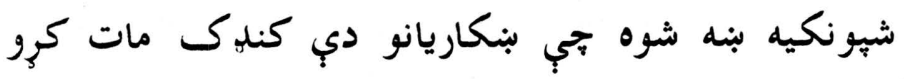

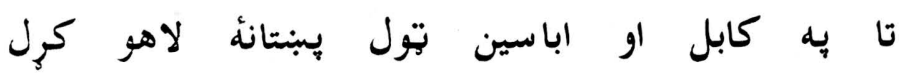
سياله به زره كبنب دي ازغ له راله د شك مات كرو

تجي د غرور شمله يبي يورته له اسمانه اوره

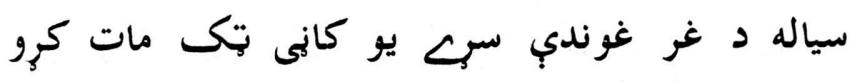




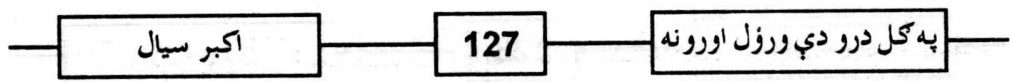

0

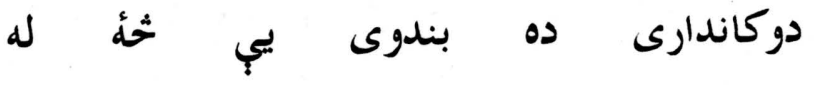

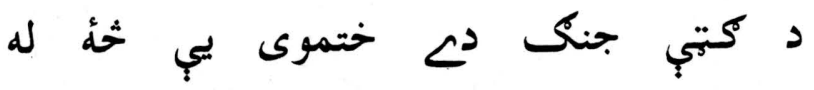

ده، سُور بنهُ ده، به وينو كبنب لنّخ

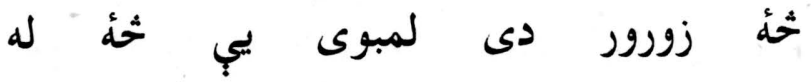

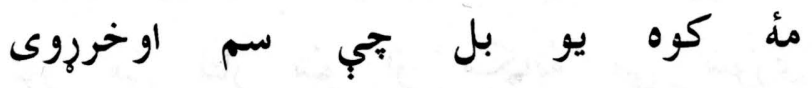

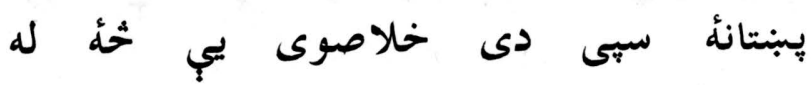

د امن دات نغاره

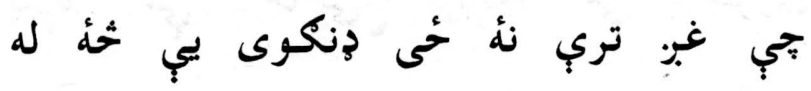

ثحٔه جل خو شته ده يه منكُل كبنب د يار

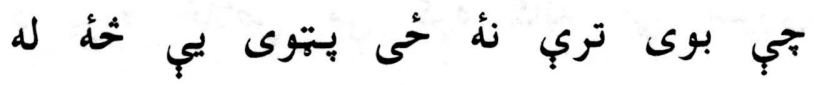

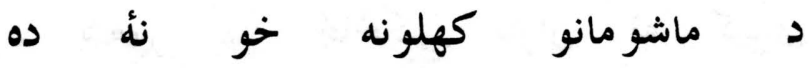

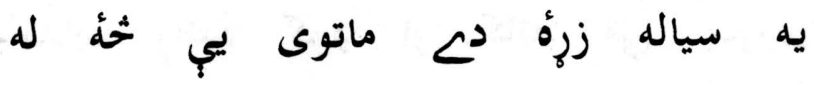




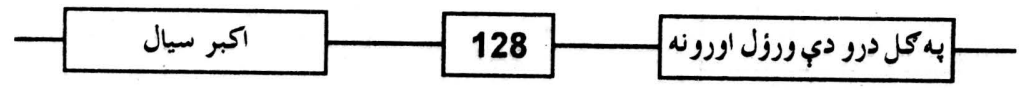

0

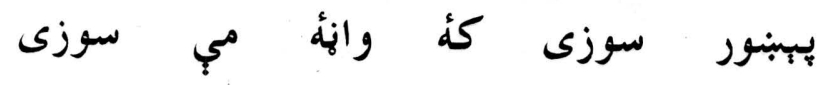

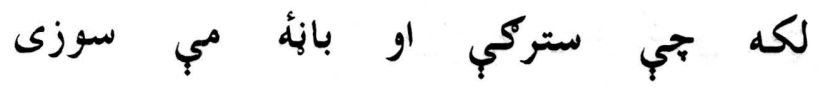

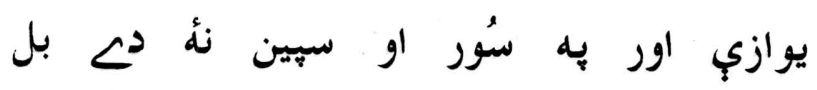

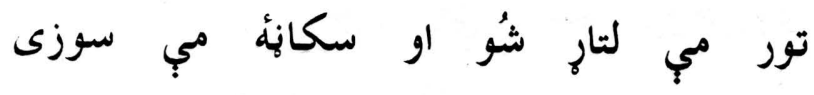

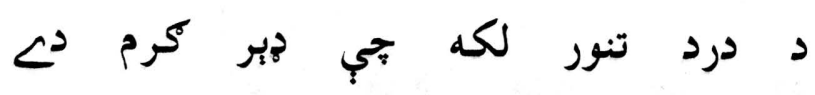

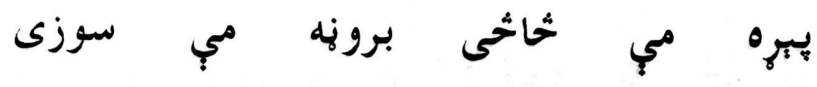

ما بكبنب شرط د زرة د دور كور ليكل د يوره خلاص مب كره كانئه مب سوزى

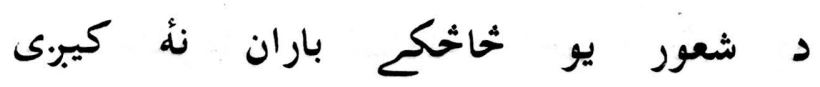

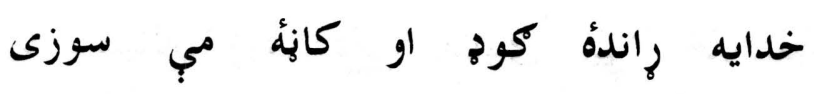




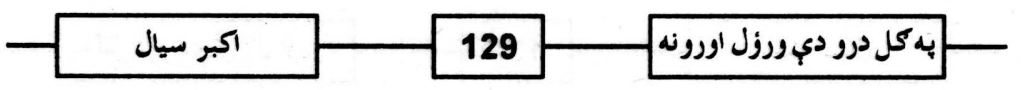

جا جي به بلاسو كبنب لمبي رانيوي

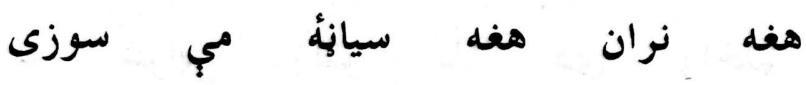

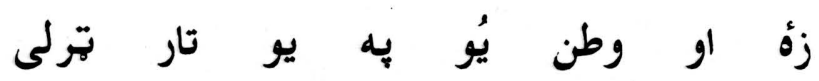

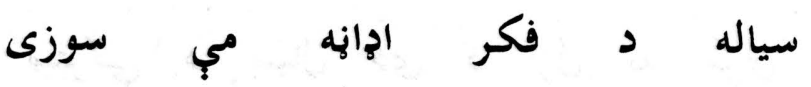




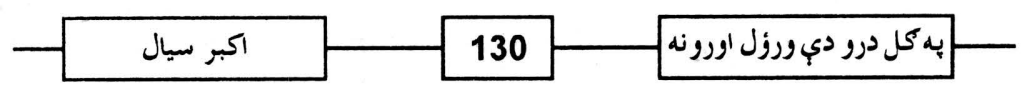

0

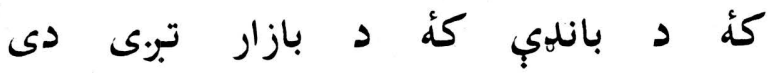

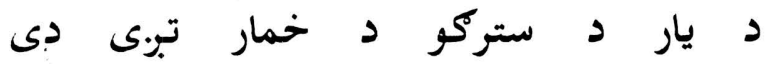

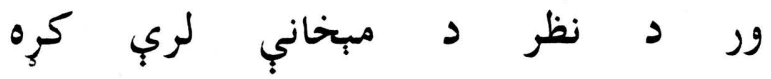

تندي راغستى د تول لبنار تبى دى دي

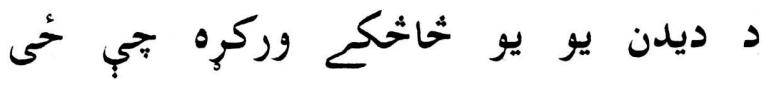

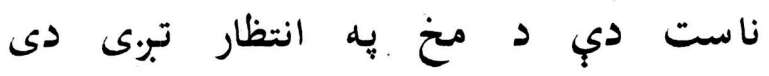

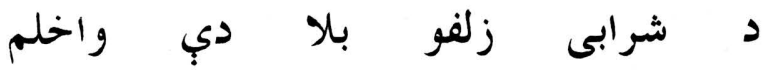

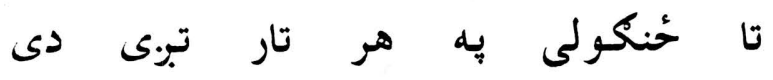

ستركي د سيال دى د ازل نه مُرب

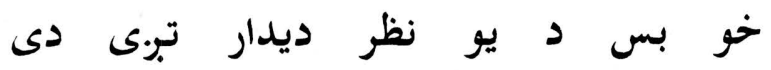




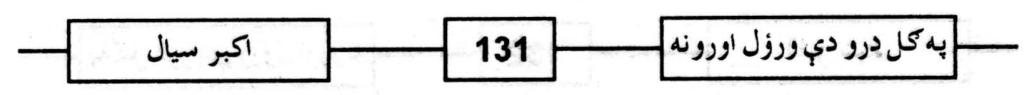

0

تكور د د زيرة خانه خراب خو راوري

تودي تودي شونلدي كلاب شخو رابره

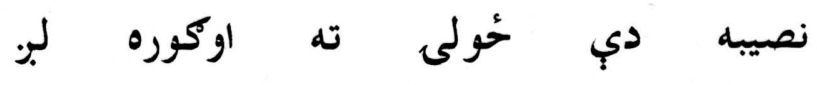

جرته د يار د دَمخ كتاب خو راورها

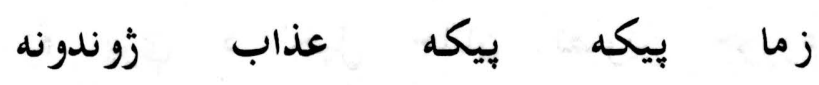

يو خل د تود سهرلى لثواب خوا راوره

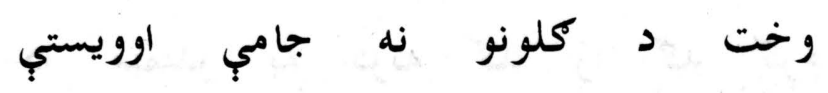

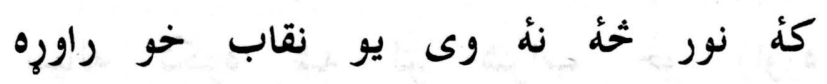

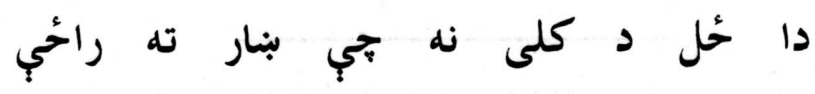

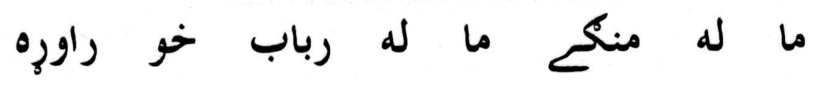




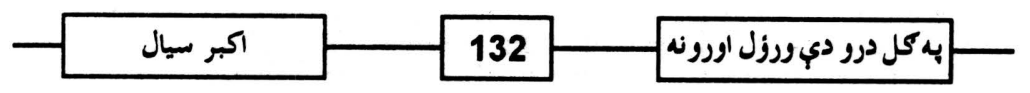

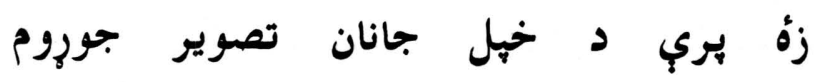

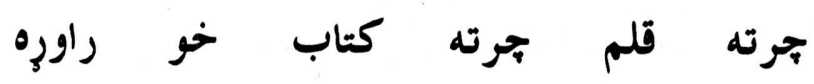

دا سمندر به درته كمه را كمه كرم سياله تكره شه لب. شراب رو راوره 

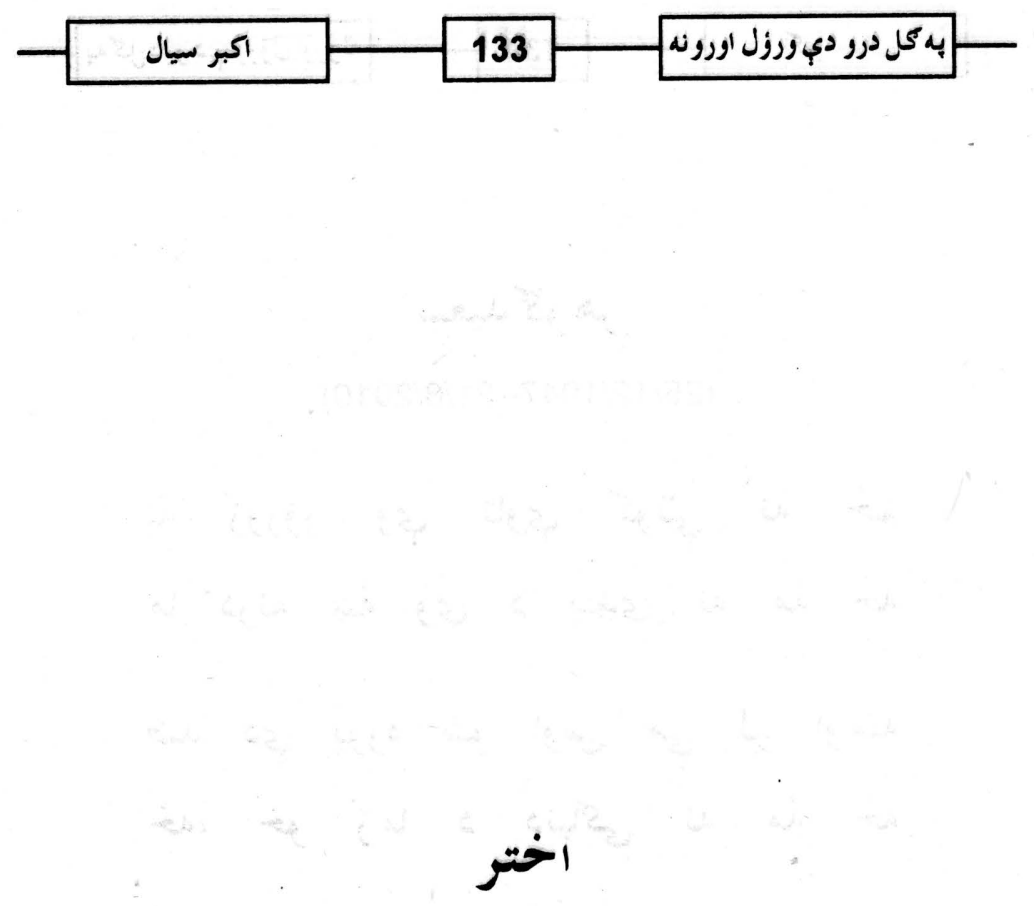

لب.ه غوغا، لب.ه زُرا، لب. به ماتم، كم شى

اختره بنه ده جي تله راشي لب. به غم، كم شى

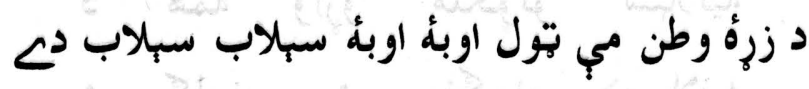

يه دي بانه به مي د دوبو ستركو نم، كم شى 


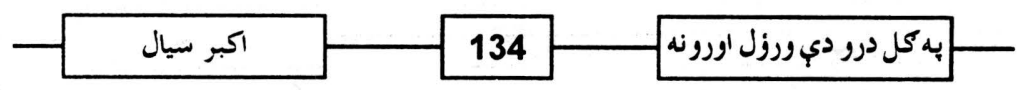

سعيدكو هر

(25/12/1947--21/8/2010)

تهٔ زورور وب تاوب كوتبي ته تهم

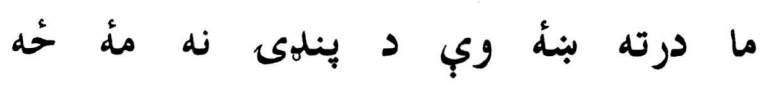
ضد دي يوره شو اوس مب لبز اومنه

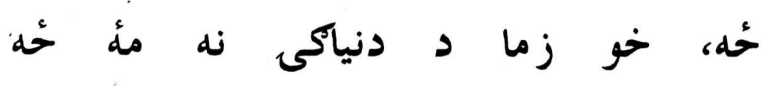

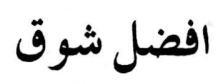

د همه وارو ملكونو سهانيه

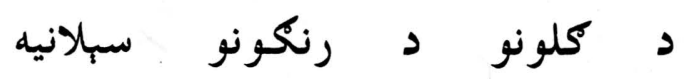

د دنيا نه د عقبى به لورى لإنى

لا مور نهٔ يب به سبلونو سنهلانيه 


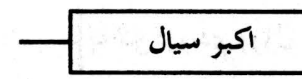

مالى د ديدن مهٔ راوره قربان بولى بولى

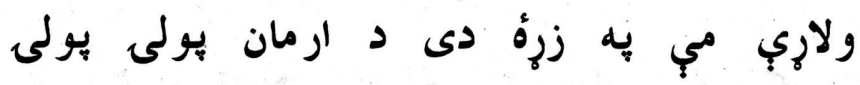

نيولى يب لل سوخته وو به ترخ كبني د دردونو

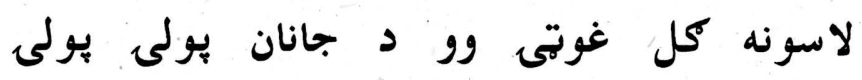

دهر هرنلر به سر كبني دى موسم ازغى تو مبلى

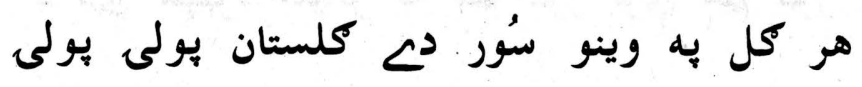

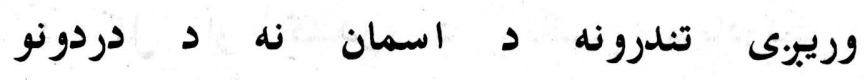
زلميان زخمى زخمى دى ماشومان بولى بولى لى دلى دلى

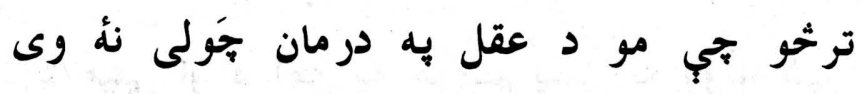

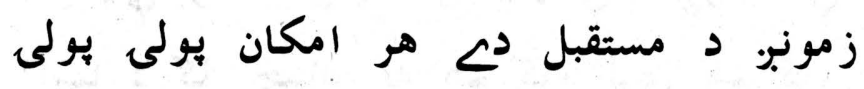

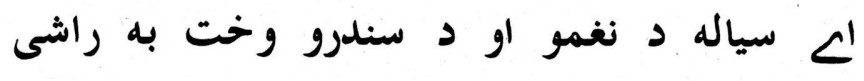
ترميو به مو به شونلو وى دوران بولى بولى لئل 


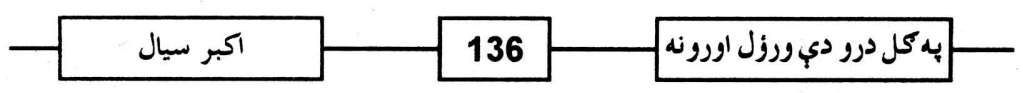

0

د زرٌة د قاتلانو نه هم كور لري هم كور

د زوند دمجر مانو نه هم كور لوي هم كور

زما وروره افغانه داسي ملك ته كلهه يوسه د دي سيرهُ مليانو نه هم كور لوي هم كور

د كل او كلبدن د رنكينر. بربادونكى د دي تورو كارغانو نه هم كور لري هم كور

د ميني او د امن هيه موسم يسب به روند شي اشنا د كل جينانو نه هم كور لري هم كور

لاسونه ترل غواريى د ازغو د جنك ببرو د جنك د هلويانو نه هم كور لوي هم كمور 


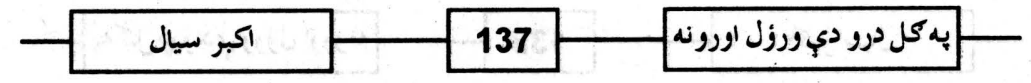

به كوتوكبني قلم لرى به ترخ كبني يب تهي دى

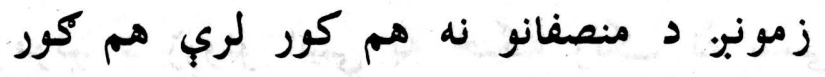

دخيل وطن د مور دسينب بى خجي خرخوى ثحوك

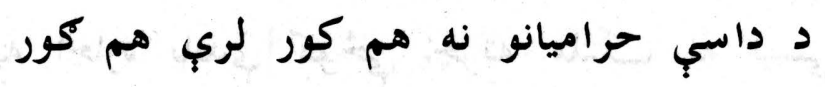

د عقل نه جي خلاص وى او دمينب نه منكر وى

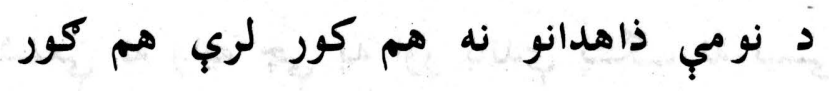

ككُونه افغانان يج به يو تبغ باندي حلال كرل د داسي قصابانو نه هم كور لري هم كور لهور

زما توره كلابه زما سياله د زئ سره سره د كل دشوكمارانو نه هم كور لري هم كور 


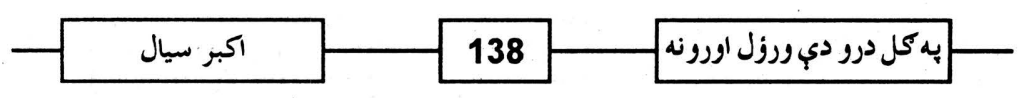

0

جي ستا د شونلمو يترى كل نهُ نيسى رنكى نهُ نيسى

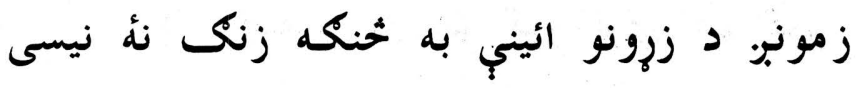

د يو نظر د مسكيتوب ديدن يوره ده كنه به اجاره باندي كوثخي جرته ملنكى نئ نيسى لئى

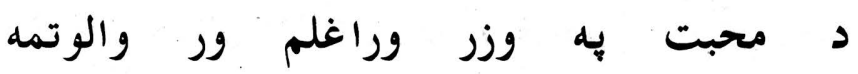
شمعي ته وايه تجي يه اور باندي يتنك نه نيسى ستا د بنكرو شرنك مي د ستركو نه خوب اوتختوهة

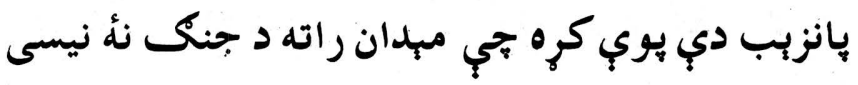
سياله زَرَه شوه محبوبه د لونكين يِه طمعه

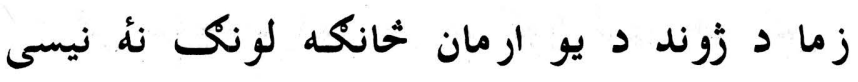




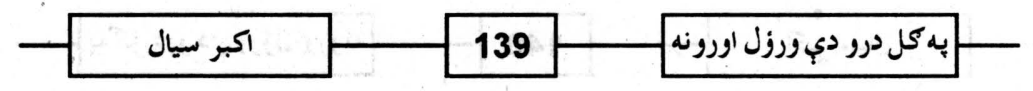

\section{0}

نا زيرة جيج روزانه كوى اقرار اقرار زرةه مي جوى

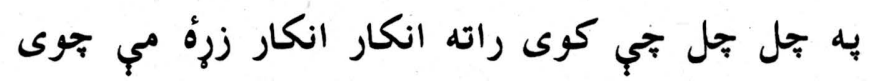

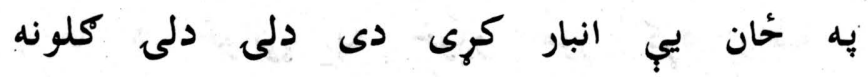

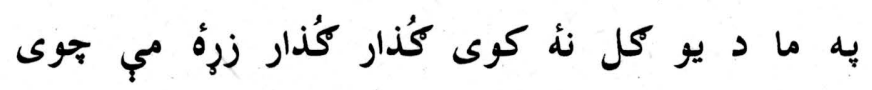

د غبرو به محفل كبني د اوبِ ستركو پِ كاسو كبني

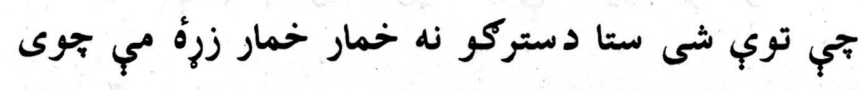

ما يو د ككلاب كل د درئ به تَل كبني ديه ساتلح

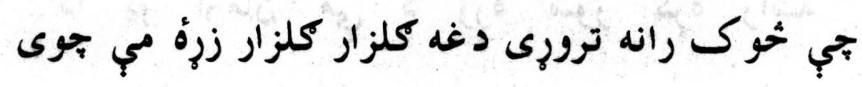

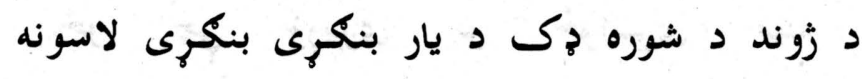

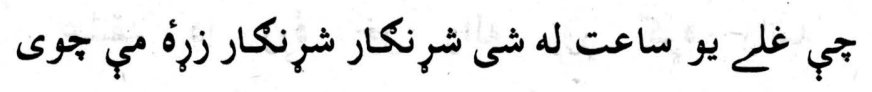
دا بنكلى خو د حسن او د خداى د نُور نه جور دى

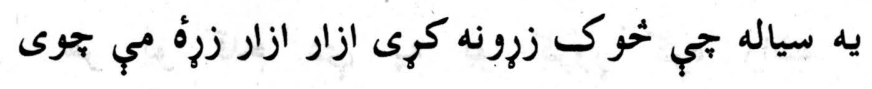




\section{0}

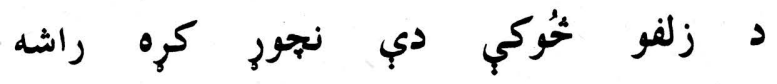

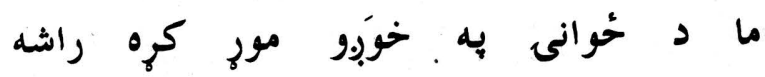

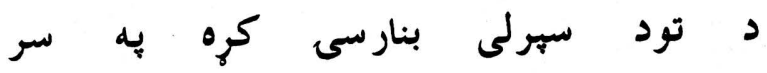
حُان دي به سره جوره كبني جور كره راشه به به

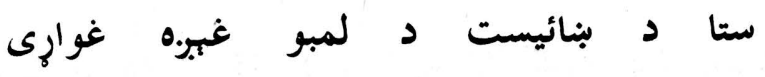

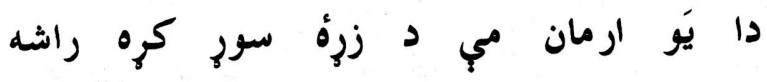

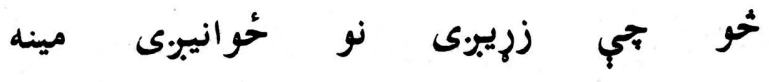

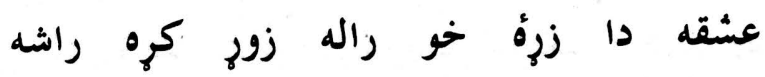

سياله د يار د, سره شخار شه دنيا هر يَو قدم دي به يَو كرور كره راشه ليه 


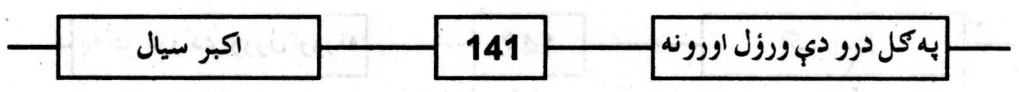

ستركو جي هيه ستركو كبني جانان له وركوله خله

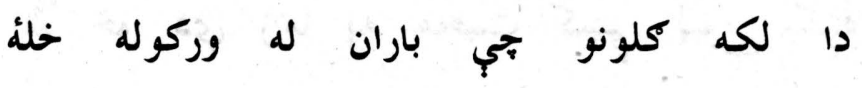

ياد دي شى تجي ستركي به مو سري شوي د ديدن به وخت ثَنك مو د يَو بل د زرةه ارمان له وركوله خله

توله شيه به ستورو دـ اسمان يه غبه كبنب اوزرل

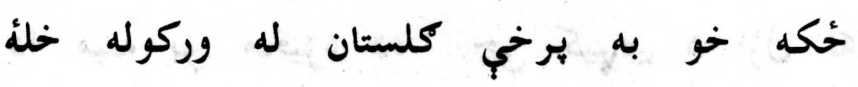

يه سيني سيوبر مى هي د كنلهؤ نه به رايورته شوب يبغلو يلوشو به دي اسمان له وركوله لهله

اوس دي د ارمان لاسونه مروره او مزي كوه تا يه نادانى كبنب به هر جان له وركوله خله

سياله د عشّق لوبه همبشه كيرى به خيل وجود مونب. د جيا نه نهُ غوبنته مونب. حُان له وركوله خله 


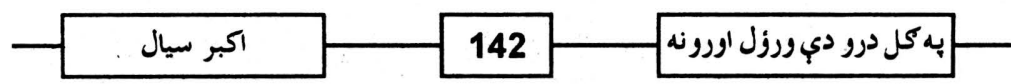

0

غرور خو دي مَولا به محبت كبنب لهونغ كره

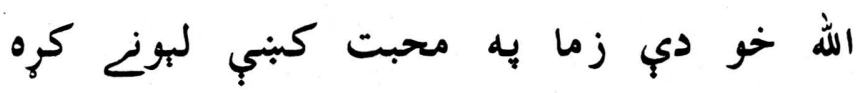

زما د خوبولو ستركو قدر جبي لب. درشى لوى خداى خو دي د جا به محبت كبني ليونغ كره

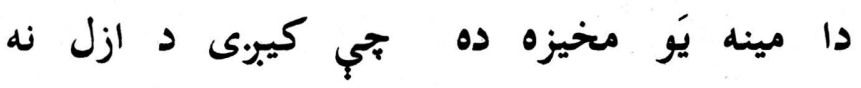
يَو كل خو د بورا به محبت كبنب لبونغ كره

راكوز به د اسمان د تاترين نه شى به زمكه

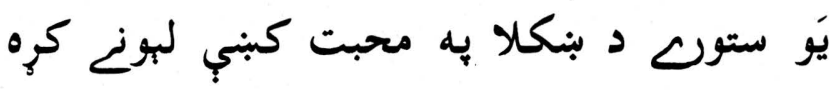

نه شور كوى نهٔ زور او نهُ مستى كوى اله سياله

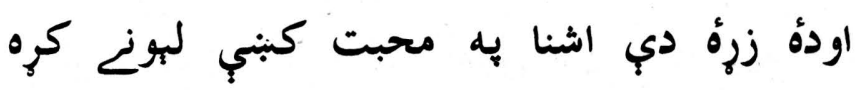




\section{0}

نرى نرى نازك د يار بنكرى بنكهي لاسونه

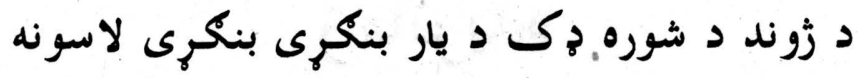
به جنج كبني به بوحم د ماركلي د غرونو بنكلى

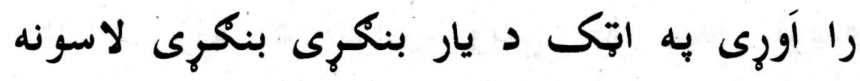
ابح ورشئ شوك كي إونيسئ د كوتي نه ملكرو

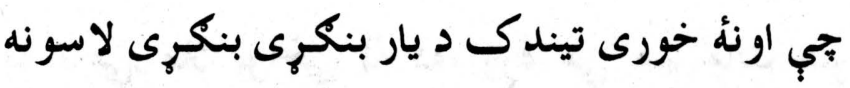
دا جا د كل به بناخ كبني اويزانه كرئنى كره به غاره كبني توبك د يار بنكرى بنكرى لاسونه ارمان ده يه زُوندونه دا دي كومه لوبه اوكره

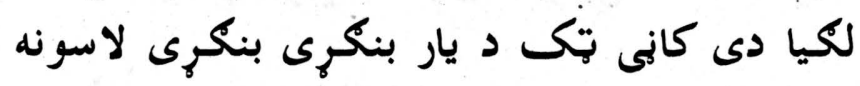
دا زوند به زوندون نهُ حسابومه بي د ميني

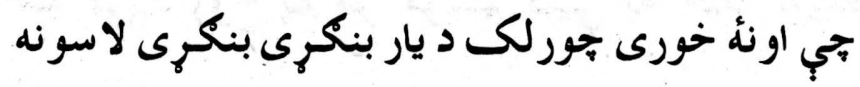
اله سياله د كجرو د باره جرته خالى مئ شه

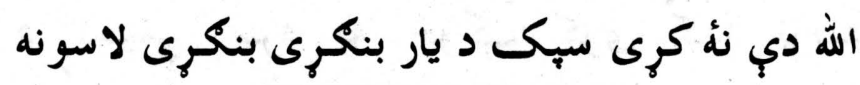




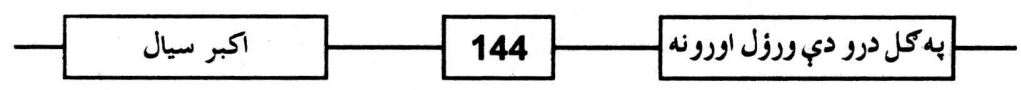

ز مانو يله

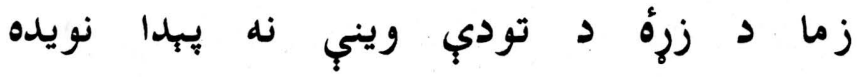
زما د زوبل زوبل مات زئ مسيحا نويده يه تامي ملا يواحُّ نهُ ده، زرهُ مي هم مات شو ستا ذذ تنكى تنكى حُوانى يه ناروغتيا نويده مونب.ه يواحُخ بيلار او زوع نهُ يُو، ياران هم يُو خداى خو دب مونب. نهُ كرى د يو بل، نه جدا نويده

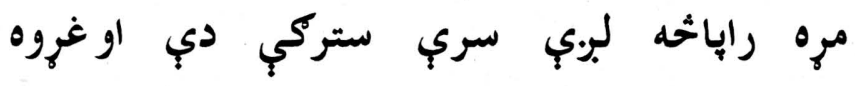
شه مي د روح يه هر موسم كبنب يه خندا نويده سبا 'يا بله ورحُ واده دم د دانش بنكليه د نسيمب سره به ثو كوى كلها نويده 


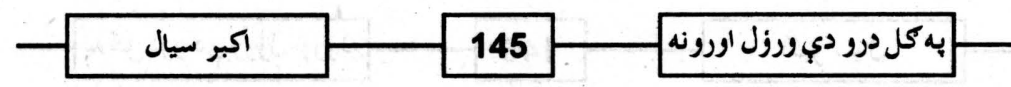

تهٔ د نكار او د جان جان نه مرور ولب يب كي

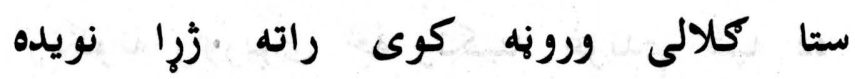
د خيل بابا د ننك او بت د فلسفي به كتاب

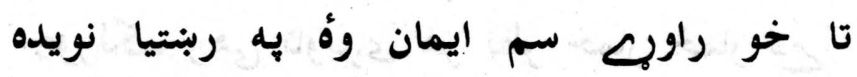
مور خو دي لبوه لبونى وه اوس شوه بنه لبونى جي تاته كورى زرأ ئي تق جوى به سودا نويده

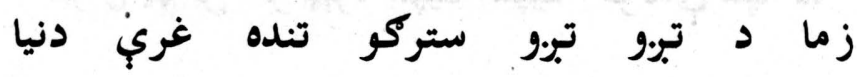
د زوندون دوه ليجي اوبئ غوارى له تا نويده د اسوبلو د غريو نه لوك زرؤ ته مي اوكوره لب. به ما دي بار كره د غمونو يو دنيا نويده

ملك مبليكل سنتر ينبلى $22 / 9 / 2010$ 


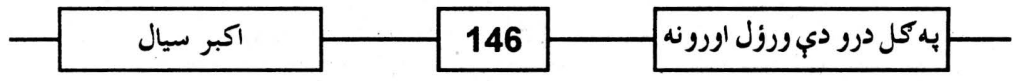

\section{0}

رنكونه راوريبرى ثحة رنككينه غوندي شبه ده

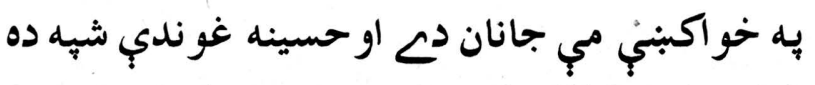
جورلك وهى تاويبرى هر نظر خمار خمار دي نشي دى تماشب دى مينه مينه غوندب شيه ده د زلفو يه تيارو كبنب تجي د مخ رنا ته كورم حهران يم نن خو ديبره سبينه سبينه غوندي شهيه ده رائه به ستركو ستركو كبني تجي اوخاندو يو بل ته بنه مسته مى برسته لونكينه غوندي شيه ده تاودة تاودة شراب خو لب. د يار د ستركو راوره ساقى ديبره سره سهه واورينه غوندي شيه ده د سيال د زرؤه يه وران كندؤ به خحنكه نهُ راخيزى شحارلي يب سيورج مى ته يو سنكينه غوندب شبه ده 


- 147 يه كل درو دي ورؤل اورونه

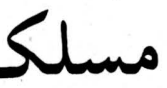

لكه كبل مي درد د زرهة به زمكه خور نهُ شو

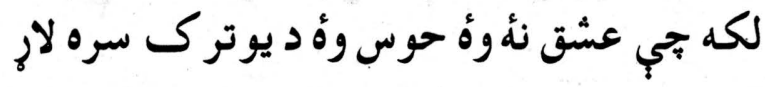

يو زوند بر ست د زُوند يه لاره تجي د تلونئو وؤن نور

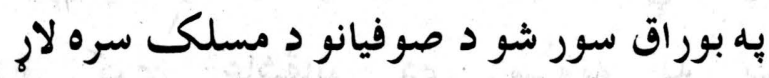




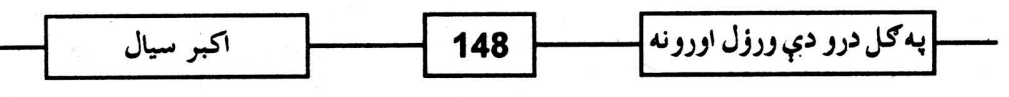

\section{0}

د زرئ نه به دي اوباسم دردونه يه بنه

راحهه راحُه جي بنكل دي كرم زخمونه به بنو

يو ستا د محبت د يقين زور تجي راسره وى بي به ببنو كبني به. دي بريباسم وختونه به بنو

دا زيرونه جرقول خو راته توقه غوندي بنكارى

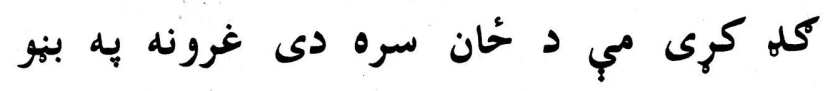

د يار د تورو ستركو به رنا مي دي قسم وى د شبي به درته بل كرم جراغونه يه بنه

د زرونو خاوندان خو سياله ستا به شانتي نهٔ وى

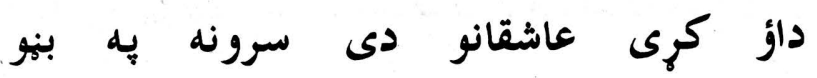




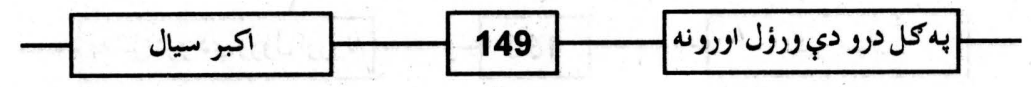

\section{0}

تُكور كئ مي دردونه كري، درمان كل بدنه دا زرةه به درله دركرمه هم حُان كل بدمنه

ويربرج د بهلتون سيلى مب بانبي بانبي نهُ كرى

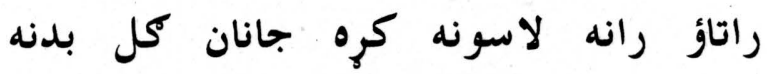

د خبل نظر به غبره كبني يب واخله جي اودة شى جبهلى مي خوبونه دى بيزوان كل بدنه

نرى نازكي كوتي، خلهُ دي كل، زلفب رببنمينب

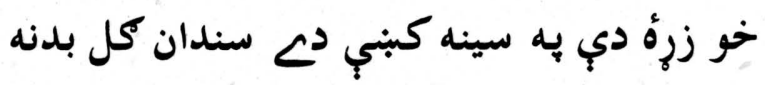

سيوج مى د خحوارلسمي ورته ناوي ناوي كيبرى دا بهرق جي وهى ستورى د آسمان كل بدنه

كرلح جي وهُ سياله تا زما د زورة به زمكه هغه كل مي اوجيبرى د ارمان كل بدنه 


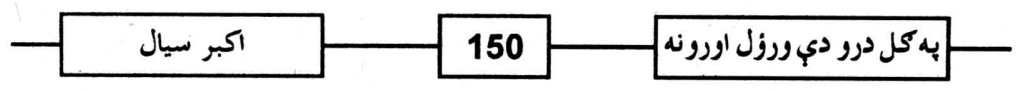

رحمت شاه سائل

زما سائله د د وطن بنكليه د كلبدنو د دمكن لبنكليه د بنايترو به سبل كبنب مئ حُه

د جين ماجين او كوهِ قاف بناييرى د يبنبور او د كابل حسينان

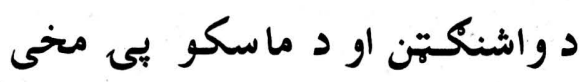
ستا نه يه خحٔ بنكلى دى د بنايهرو به سبل كبني مئ حُه

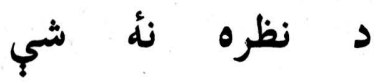
ورك د خيل كانى كانى غره نهُ شب ني د خيل سنكره نهٔ شي

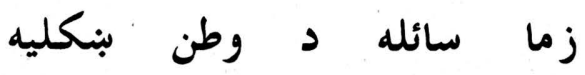
د كلبدنو د دمكن مسكليه 


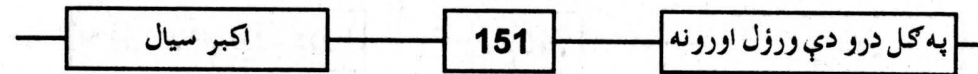

تهٔ خو به خيله د خيل خيال د حسن · د ماه جبينو د جمال د حسن د رنكى او نور هبكر يبي

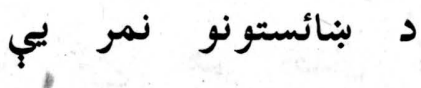

د بنايبرو به سبل كبنب مئ حُه

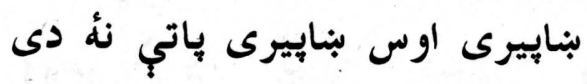

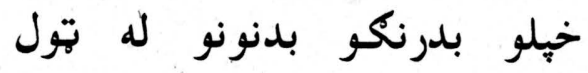
ستا د نظر د بنائست رنكـ بـتوى بـون

زما سائله د وطن بائله د كلبدنو د م مسكن سائله د بنايبرو به سبل كبني مئ حُه

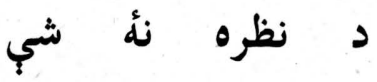




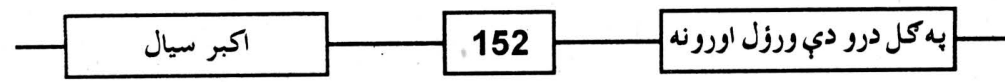

جمال شاه

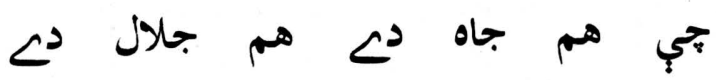

تجي هم شاه لد هم هم همال

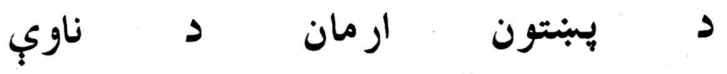

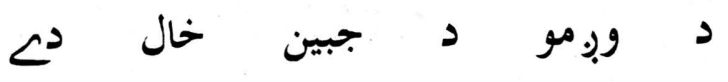

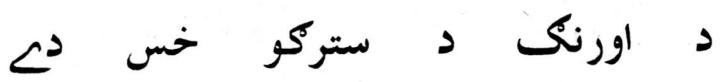

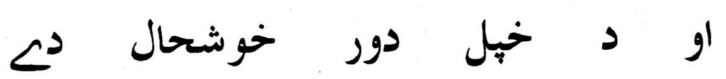

لوى دروبش دي لوى ننكيال دي

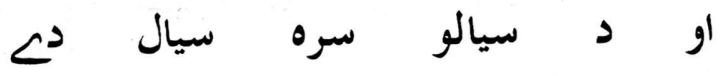




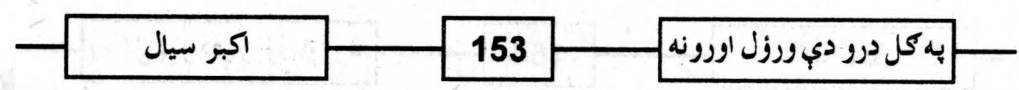

هُاكتز خالق زيار

جي جلال د بير روبنان ديان

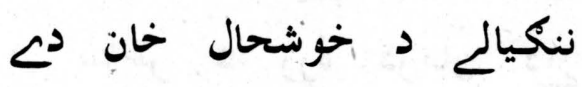

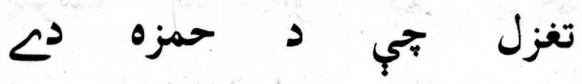

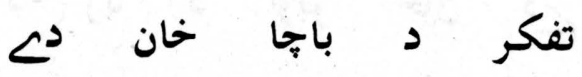

زوند برست ده قام برسل دي

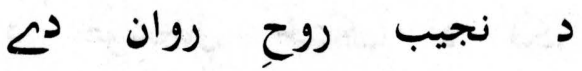

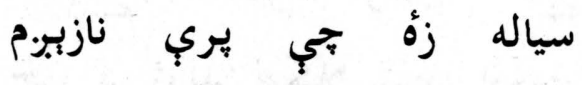

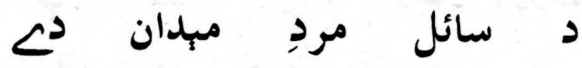




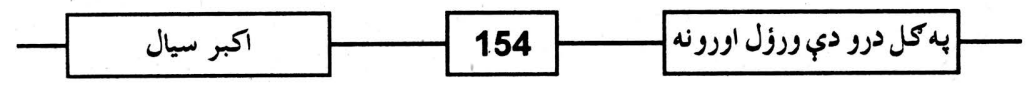

اختر زمان ختبك

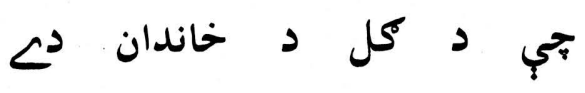

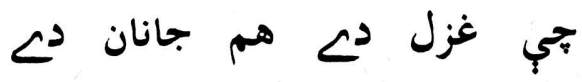

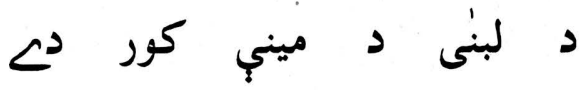

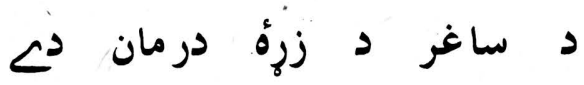

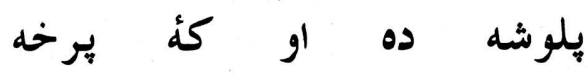

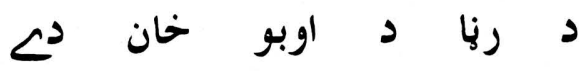

به هبنتو او هيت مئين

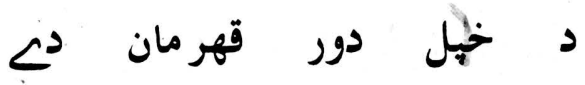

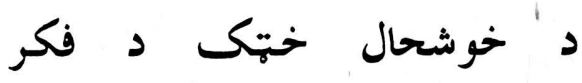

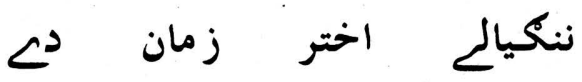

جي د زُوند بنكلا تري اوورى

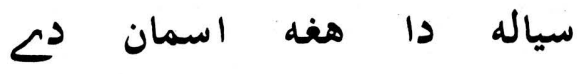




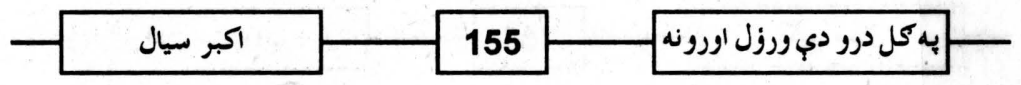

\section{نو كال}

مونبر به دي دنيا كبني خبل وطن او خبل ائين لرو

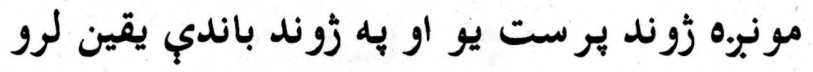

مونبر لكه مجهى به نسرو كلونو بنهدلى يُو

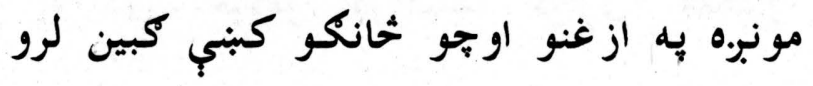

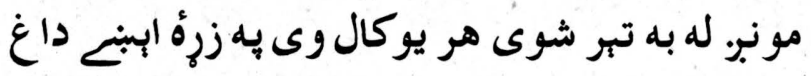

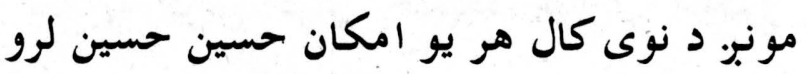




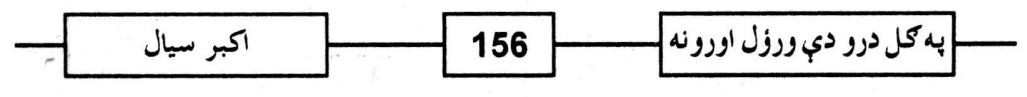

مبارزه

د خجل كور نه راواتهٔ غوإى ملككرو

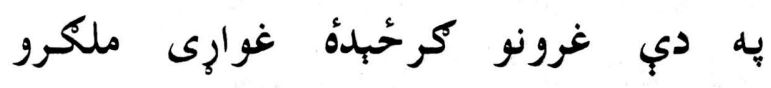

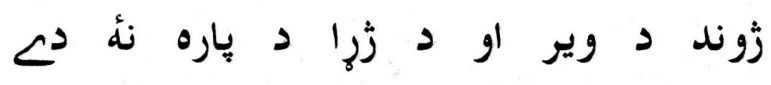
بنهُ به كرس كرس خندبدة غوارى ملكرو 


$$
\text { اكبر سيال }
$$

يم هِبنبون د كابلى نه مي زرة نهُ صبريبرى د قندهار د يو جينى نه مي زئه نهأه صبريبرى د كوهِ قاف د بنايبرو نه به زرأ صبر كرمه د يبنتونخوا د غرشنى نه مب زئه نهُ صبريبرى دا ستا د زانبي شان غرى خلله دي وره كل غوتى لئ

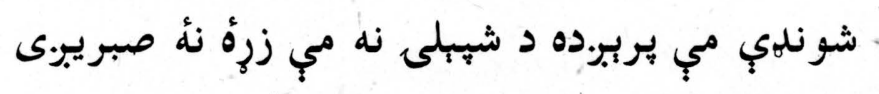
ـ به دي حسين اسلام اباد كبنب بنُكلى لب. خو نهُ دى

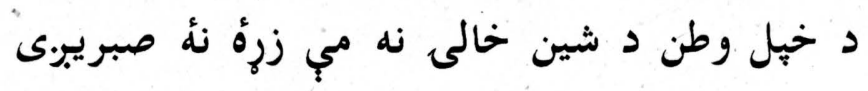
يمه بِنتون بِه امريكه كؤ به يورب كبنب اوسم

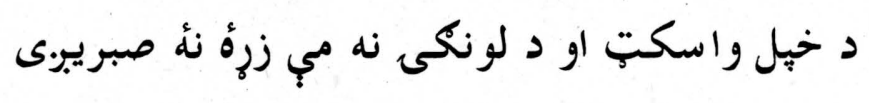

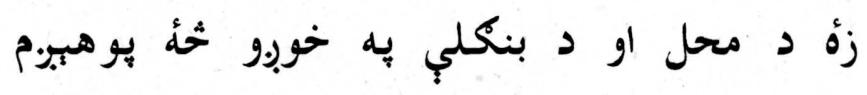

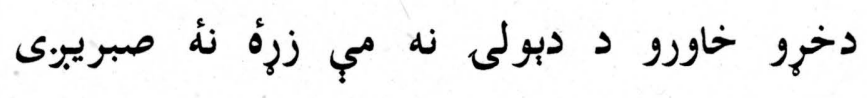

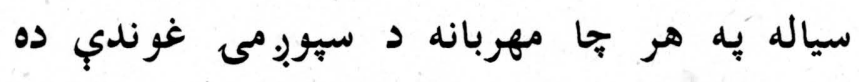
بيا هم د داسب هردرى نه مي زئه نهُ صبريبرى 


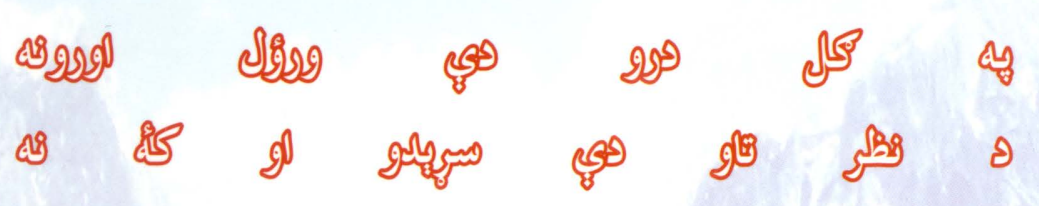

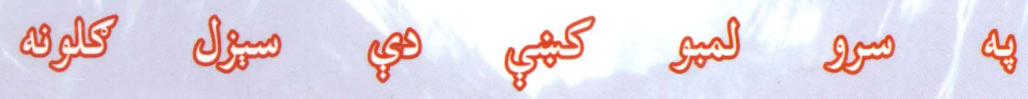

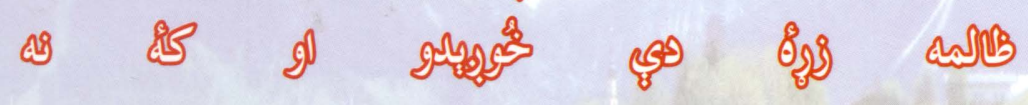
(1) 